Historic, Archive Document

Do not assume content reflects current scientific knowledge, policies, or practices. 



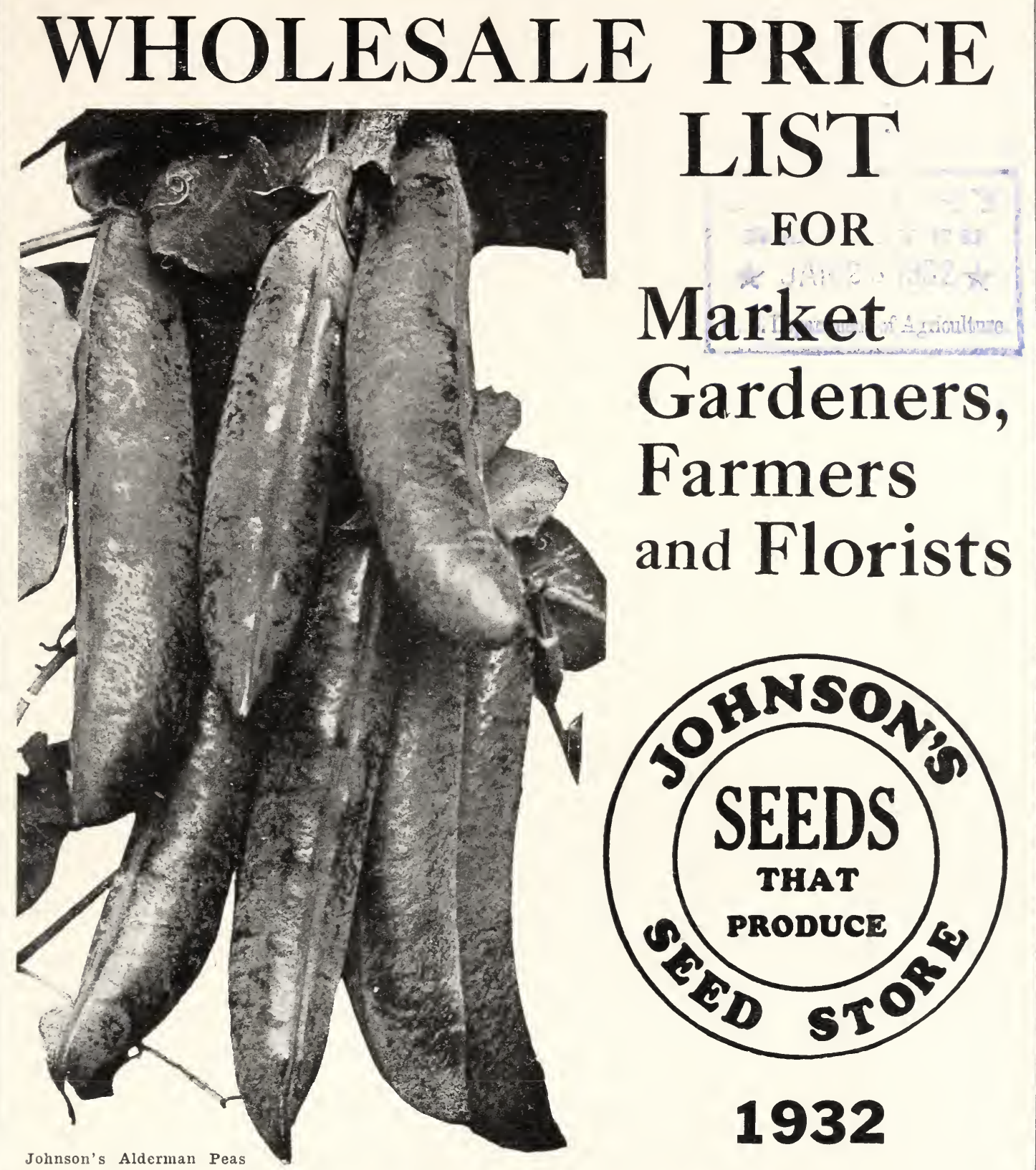

\section{PLANT THE BEST}

JoHnSONS SEEd StORE CLEVELAND 2172 E. NINTH ST. OHIO

Cleveland's Leading and Most Convenient Seed Store 


\section{JOHNSON'S "SEEDS THAT PRODUCE" \\ E. MARKET FOR GARDENERS}

For over 39 years it has been our constant aim to furnish only seeds of the highest quality, always believing that in so doing we render a real service. We do not pretend to compete in price with unreliable or careless growers or dealers, but always aim to produce strictly high grade seeds at a moderate cost. We handle nothing we do not believe to be the very best obtainable and intend that our prices shall be as low as is consistent with this quality. We consider our best advertisement to be the quality of our seeds and on this basis we solicit your patronage.

JOHNSON'S SEED STORE,

ROY B. JOHNSON.

\section{SPECIAL FREE DELIVERY OFFER}

If your order is for small seeds only and does not include any Peas, Beans or Corn, we will PREPAY CHARGES BY PARCEL POST, EXPRESS OR FREIGHT, PROVIDING it amounts to $\$ 10.00$ or over and remittance is made with the order. This includes all vegetable seeds quoted by the pound. OR, if your order for seeds amounts to $\$ 20.00$ or more and not more than half is composed of Peas, Beans or Corn, WE WILL PREPAY THE CHARGES by express or freight, at our option.

CHARGE ACCOUNTS are opened to persons of approved credit. C. O. D. ORDERS must be accompanied by remittance covering at least one-fourth of the total amount of the order.

THE SEEDS OFFERED IN THIS CATALOG HAVE BEEN CAREFULLY GROWN, SKILLFULLY HANDLED AND ACCURATELY TESTED FOR GERMINATION; and while we believe they are of first class quality in every respect, we give no warranty, expressed or implied, as to description, purity, productiveness, or any other matter of any seeds, bulbs or plants we send out and we will not be in any way responsible for the crop. If the purchaser does not accept the goods on these terms, they are to be returned at once.

\section{THE BEST STANDARD VARIETIES FOR 1932}

BEETS, JOHNSON'S EARLY WONDERGlobe shaped, uniform in size. Skin is smooth and flesh is a deep blood red. Early and fine for market. Oz., I5c; 1/4 lb., 40c; lb., \$I.00; 5 lbs., \$4.50. Prepaid.

BROCCOLI, JOHNSON'S "CLEVELAND MARKET"-True Italian sprouting. Try some of this elegant new variety of ours. Pkt., I5c; $1 / 2$ oz., 30c; Oz., 55c; $1 / 4$ lb., \$I.go. Postpaid.

CABBAGE, SPECIAL GOLDEN ACRE-A rather small, but solid, heavy head. Very early. $1 / 2$ cz., 3oc; oz., 5oc; $1 / 4$ lb., \$1.45; lb., \$4.75. Postpaid.

CARROT, SELECT CHANTENAY-Specially selected for our trade by a long established carrot grower. Oz., Ioc; 1/4 lb., 30c; lb., 90c; 5 lbs., \$4.25; io lbs., $\$ 8.00$. Postpaid.

CELERY, JOHNSON'S GOLDEN PLUME -Originator's stock. Fast growing heart, and free from stringiness. $1 / 2$ oz., 6oc; oz., \$I.00; $1 / 4$ lb., \$3.8o. Postpaid.

CORN, JOHNSON'S GOLDEN STANDARD -This has become the Standard Early Yellow Corn here among our gardener customers. 2 lbs., 50c; 6 lbs., \$I.IO; I2 lbs., \$1.90; 48 lbs., $\$ 7.00$.
LETTUCE, JOHNSON'S BIG BOSTONUniform heads and true to type. Oz., I5c; $1 / 4$ lb., 45c; lb., \$1.50; 5 lbs., \$6.90. Postpaid.

MUSKMELON, BENDER'S SURPRISEThe best large, early oval shaped market melon. Oz., I5c; $1 / 4$ lb., 35c; I lb., \$I.25; 5 lbs., \$5.25. Postpaid.

ONION, JOHNSON'S SELECTED OHIO YELLOW GLOBE-Ripens early with a clear even color. Oz., 25c; $1 / 4$ lb., 70c; lb., \$2.25; 5 lbs., \$II.00. Prepaid.

PEAS, LAXTONIAN-The best early, giantpodded dwarf sort. 2 lbs., 6oc; 7 lbs., \$r.50; I4 lbs., \$2.75; 56 lbs., \$ro.50.

PEPPER, CALIFORNIA WONDER-Fruits average 4 to $4 \frac{\mathrm{T}}{2}$ inches thick. An elegant market variety. $1 / 2$ oz., 35c; oz., 6oc; $1 / 4$ lb., \$I.90; 1b., \$6.50. Postpaid.

TOMATO, JOHNSON'S SELECT EARLIANA-The best early, deep scarlet sort for market. 1/2 oz., 20c; oz., 35c; 1/4 lb., \$r.00; lb., \$3.50. Postpaid.

TURNIP, PURPLE TOP WHITE GLOBE -We have excellent stock of this well known variety. Oz., Ioc; $1 / 4$ lb., 20c; 1b., 55c; 5 lbs., $\$ 2.50$; Io lbs., \$4.75. Postpaid. 


\section{Johnson's "Seeds That Produce" For Market Gardeners and Truckers WE PREPAY}

All small seeds such as Asparagus, Beets, Cabbage, Carrots, Cauliflower, Celery, Cucumbers, Egg Plant, Lettuce, Melons, Onion, Pepper, Radish, Spinach, Squash, Tomato and Turnips, are prepaid at prices quoted. If your order amounts to $\$ 5.00$ or over and half the amount is for heavy seeds we will prepay. Beans, Corn and Peas, if ordered alone must go at customer's expense.

\section{ASPARAGUS}

(Sparagio-Szparagi)

Oz. 1/4 lb. I lb.

Early French Giant .......\$o.1o \$0.20 \$0.70

Early Giant Argenteuil ..... . .

Palmetto ................. . . $\quad$.20 $\quad .70$

Washington Rustproof ....

\section{Mary Washington Asparagus}

This is a selection from the Washington showing a marked improvement in every respect. It is much larger than the ordinary strain and is slightly earlier. The tips are very compact and are a rich purplish-green and the whole stalk from base to tip is remarkably tender. Pkt., IOc; 1/2 oz., I5c; Oz., 20c; 1/4 lb., 5oc; lb., \$I.40; Io lbs., \$I 2.50 , Postpaid.

\section{BEANS, BUSH Wax or Yellow Podded}

(Fagnoli-Fasola)

CULTURE-Bush Beans may be had throughout the season, by planting at intervals of two weeks, from the beginning of May until the middle of August; they should be planted in drills, two feet apart, one seed every four inches covered one inch deep. I quart (2 lbs.) will plant a $200 \mathrm{ft}$. row. I to 2 bushels to the acre.

UNRIVALED WAX-This excellent sort produces an enormous crop of pods in about 55 days, on a small, vigorous-growing, dwarf plant. The pods are about $5 \frac{1}{2}$ inches long, semi-flat, fleshy, of fine texture, and excellent flavor. They remain in good condition for a long time. Color of pods a beautiful light yellow and almost transparent. The dry Beans are light brown in color. 2 lbs., 65c; 7 lbs., \$1.75; I5 lbs., \$3.00; 6o lbs., \$10.80.

CRACKER JACK WAX-A high-quality, flatpodded, stringless early variety. Pods 6 to $6 \frac{1}{2}$ inches long, quite broad and uniformly curved, fleshy, stringless and brittle, with little fiber. Plant vigorous and productive. Color of pod is a decided bright yellow. Seed yellow, kidney shaped. 2 lbs., 65c; 7 lbs., \$I.55; I5 lbs., $\$ 2.70 ; 60$ lbs., \$9.6o.

WARDWELL'S KIDNEY WAX - A very popular variety of $\mathrm{W}^{\mathrm{T}}$ ax Bean, bearing long, flat pods of a delicate waxy yellow, stringless and brittle, producing a heavy crop. The pods mature a little later than Golden Wax, but are produced in great abundance. 2 lbs., 5oc; 7 lbs., \$1.50; I5 lbs., \$2.80; 6o lbs., \$10.20.

SURE-CROP STRINGLESS WAX -A valu. able variety of Dwarf Wax Bean, which while not related to the well-known Currie's Rust. Proof Wax, bears a great resemblance to it in plant and seed. It is very productive, bearing large, handsome golden yellow pods in great abundance. 2 lbs., 55c; 7 lbs., \$I.65; I5 lbs. $\$ 3.00 ; 60$ lbs., \$10.80.

\begin{tabular}{|c|c|c|c|c|}
\hline $\begin{array}{l}\text { Currie's Rustproof } \\
\quad \text { Wax } \ldots \ldots \ldots \ldots\end{array}$ & 5 & $\$ 1.65$ & $\$ 3.00$ & $\$$ I0.80 \\
\hline 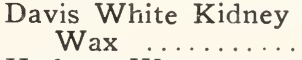 & & & 5 & \\
\hline $\begin{array}{l}\text { Iodson Wax } \\
\text { urpee's New Kidney }\end{array}$ & & I. 65 & & \\
\hline $\begin{array}{l}\text { Wax } \ldots . . . . \\
\text { Webber Wax }\end{array}$ & $\begin{array}{l}.55 \\
.65\end{array}$ & & & $\begin{array}{r}10.80 \\
9.60\end{array}$ \\
\hline Wax Pod Black & .60 & I. 6 & .70 & 9.6 \\
\hline 5. & .6 & 1.0 & 2.85 & \\
\hline
\end{tabular}

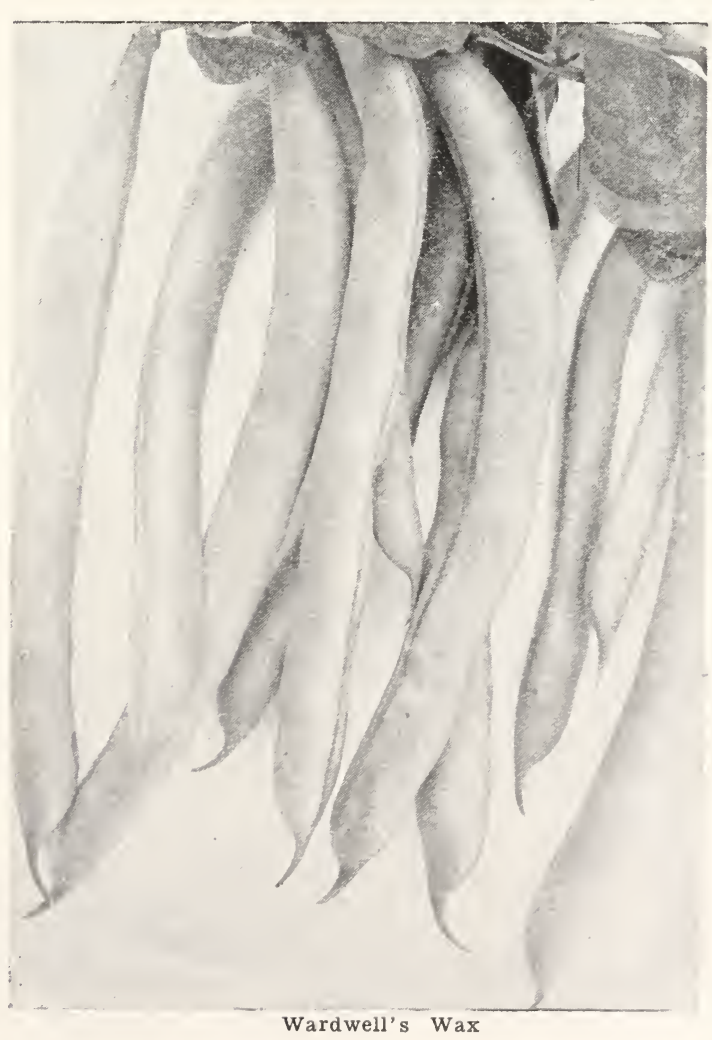




\section{BEANS}

\section{Dwarf Green Podded}

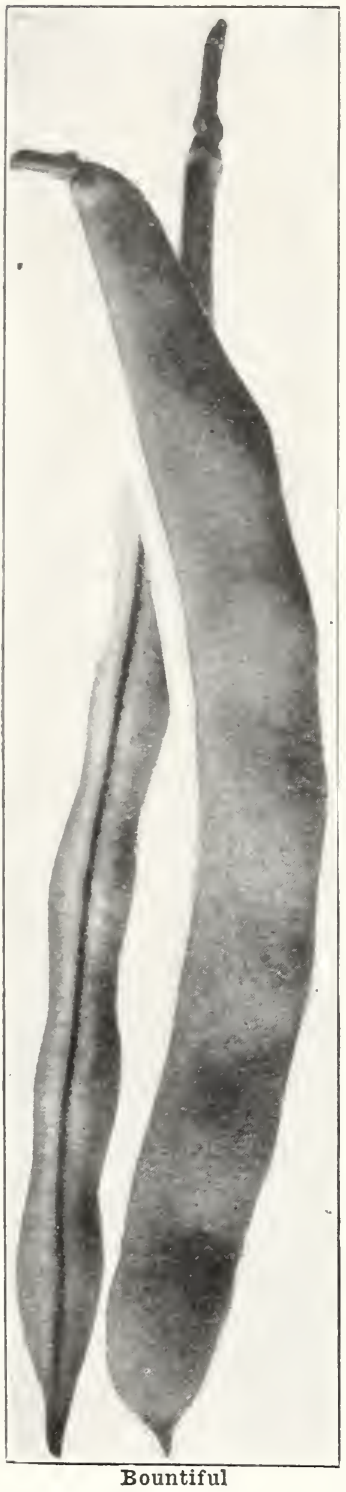

B L A C K VALENTINE-Beautiful large pods about 6 inches long, slender, round and nearly straight; dark green in color. An early, productive, profi t a b le gardener's variety. 2 lbs., 40c; 7 lbs., \$I.25; I5 lbs. $\$ 2.25$; 60 lbs., \$8.0o.

BOUNTIFUL - This variety is well known and is one of the best green-podded beans on the market for market gardeners; 6 to 7 inches long, broad, flat, th ick, m eat y a nd stringless. 2 lbs., $50 \mathrm{c}$ : 7 lbs., \$I.50; I5 lbs. \$2.70; 60 lbs., \$9.6o.

BURPEE'S STRINGLESS GREEN POD - Early, hardy, vigorous and productive. Pods large, round and dark green in color, strictly stringless. 2 lbs., 5oc; 7 lbs., \$1.6o; I5 lbs., $\$ 2.85$; 6 o lbs., $\$$ I0.20.

GIANT S T R I N GLESS GREEN POD - Somewhat similar to B ur p e e's Stringless, but pod is a little longer, straighter and more slender. 2 lbs., 5oc; 7 lbs. \$I.6o; I5 lbs., $\$ 2.85$; 60 lbs., \$10.20.

\section{IMPROVED EARLY} RED VALENTINEA very hardy, early and productive standard sort. 2 lbs., 50c; 7 lbs., \$I.55; 15 lbs. \$2.75; 60 lbs., \$10.00.

REFUGEE, or I000 TO I-A very productive, hardy, vigorous late sort. Pods round and almost stri11gless. 2 lbs., 50c; 7 lbs., \$I.50; I5 lbs., $\$ 2.60 ; 60$ lbs., \$9.6o.

FULL MEASURE-A round, green-podded bush bean. The pods are 6 inches long, stringless and are of extremely good quality. 2 lbs., 6oc; 7 lbs., \$1.6o; I 5 lbs., \$2.90; 6o lbs., \$10.9o.

LARGE WHITE MARROW-2 lbs., 50c; 7 lbs., \$1.40; I5 lbs., \$2.55; 60 lbs., \$9.00.

BOSTON SMALL PEA-2 lbs., 50c; 7 lbs., \$1.00; I5 lbs., \$I.85; 6o lbs., \$7.00.

LARGE WHITE KIDNEY-2 lbs.. 50c; 7 lbs., $\$$ I.40; I 5 lbs., \$2.55; 60 lbs., \$9.0o.

\section{Pole or Running Beans}

IDEAL MARKET-This variety will mature about a week ahead of Kentucky Wonder. The pods are 5 inches long, round, curved, green and stringless. It is extremely productive and this, together with its earliness, should make Ideal Market popular with gardeners. $2 \mathrm{lbs}$., 75c; 7 lbs., \$I.95; I5 lbs., \$3.6o; 60 lbs., \$I3.25. KENTUCKY WONDER POLE-An old favorite, with long, fleshy, deeply saddle-backed green pods. Very prolific, producing an abundance of fine, crisp Beans until late in the season. They are slightly stringy but of the best quality. 2 lbs., 6oc; 7 lbs., \$1.50; I5 lbs., \$2.75; 60 lbs., \$9.6o.

KENTUCKY WONDER WAX-Quite similar to the Kentucky Wonder or Old Homestead, except in the color of pods, which in this one are light waxy yellow. It has a thick, broad pod, very tender, of delicious flavor and stringless. 2 lbs., 6oc; 7 lbs., \$1.65; I5 lbs., \$3.00; 6o lbs., \$10.85.

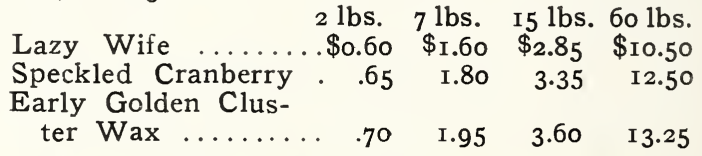

\section{Dwarf or Bush Lima Beans}

BURPEE'S IMPROVED BUSH-Both beans and pods larger than the old type; average one more bean to the pod; beans larger and thicker than in the old form. 2 lbs., 70c; 7 lbs., \$I.90; I5 lbs., \$3.65; 6o lbs., \$13.25.

FORDHOOK BUSH-A most excellent variety and exceedingly popular with market gardeners. Pods about 5 inches long, containing 4 or 5 large, oval-shaped, very thick white beans of the so-called Potato Lima type. $2 \mathrm{lbs}$., 9oc; 7 lbs., \$2.35; I5 lbs., \$3.75; 6 o lbs., \$13.8o.

HENDERSON'S BUSH-A vigorous, hardy, very early and small type of Bush Lima; much in favor with canners. Pods small, about 3 inches long, containing three to four small, flat, white beans of good quality. 2 lbs., 6oc; 7 lbs., \$1.65; 15 lbs., \$3.00; 6o lbs., \$10.80.

\section{Pole Lima Beans}

EARLY LEVIATHAN-Very early, of superior quality and wonderfully productive. Superior in size of Bean, pod, and productiveness. 2 lbs., 6oc; 7 lbs., \$I.80; I5 lbs., \$3.35; 60 lbs., \$12.00.

GIANT-PODDED-The largest-podded Lima extremely vigorous in growth; matures in midseason. The pods sometimes measure 7 inches long by $\mathrm{I} 1 / 2$ inches broad and are borne in clusters of six to eight, with extra large Beans of excellent quality. 2 lbs., 70c; 7 lbs., \$2.I5; I5 lbs., \$3.70; 60 lbs., \$13.00.

CARPINTERIA-The pods contain three or four large, fat Beans, somewhat thicker than those of the ordinary Pole Limas, and which retain the green tint even when dry. 2 lbs., 75c; 7 lbs., \$1.75; I5 lbs., \$2.80; 6o lbs., \$10.50. KING OF THE GARDEN--Vigorous grower, pods containing five to six large Beans. The vines grow strong and yield heavily. A very fine variety. 2 lbs., $70 \mathrm{c} ; 7 \mathrm{lbs}$., \$I.75; I5 lbs., $\$ 2.85$; 60 lbs., \$10.50. 


\section{BEETS, Table Sorts}

JOHNSON'S EARLY WONDER-This beet is the result of many years of expert selection with a special strain of Crosby's as a basis. In this new beet we have perfect form, small tops and tap root, beautiful color, and extra early maturity. For forcing and bunching it is unequalled by anything on the market while the rich color, tenderness and flavor of the flesh make it extremely desirable on the table. Oz., I5c; $1 / 4$ lb., 40c; lb., \$I.00; 5 lbs., \$4.50; Io lbs., \$9.00. Prepaid.

CROSBY'S IMPROVED EGYPTIAN-IVe have an unequalled strain of this superb. extra early sort. Roots are flattened globe shaped; skin very dark red, flesh a trifle lighter in color and lightly zoned; tops small. Oz., Ioc; 1/4 lb., 25c; lb., 9oc; 5 lbs., \$4.25; Io lbs., \$8.0o. Prepaid.

DETROIT DARK RED-One of the very best sorts for home or market garden and for canning purposes. Roots uniformly smooth, of medium size and globe shaped; skin dark red, flesh solid vermilion red. Our special stock of this variety shows no white zones. Tops are small, upright, dark green, shaded red. Oz., Ioc; $1 / 4$ lb., 30c; lb., 90c; 5 lbs., $\$ 4.25$; Io lbs., \$8.0o. Prepaid.

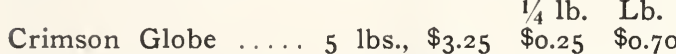
Dewing's Improved Blood Turnip . $.25 \quad .75$ Edmund's Early Turnip .......... $.20 \quad .70$ Extra-Early Dark Red Egyptian .. $.25 \quad .75$ Extra-Early Eclipse .............. .30 .85

\section{Swiss Chard Beets}

FORDHOOK GIANT-Leaves broad, upright in growth, very dark green, savoyed, with broad white midrib. This variety, on account of its giant size and pleasing deep green color, will probably supersede other sorts. Oz., I5C; $1 / 4$ lb., 30c; lb., 9oc; Io lbs., \$8.50.

Lucullus Oz. $1 / 4$ lb. Lb. Silver Greens ........ . . ${ }^{2} \quad .25 \quad .80$

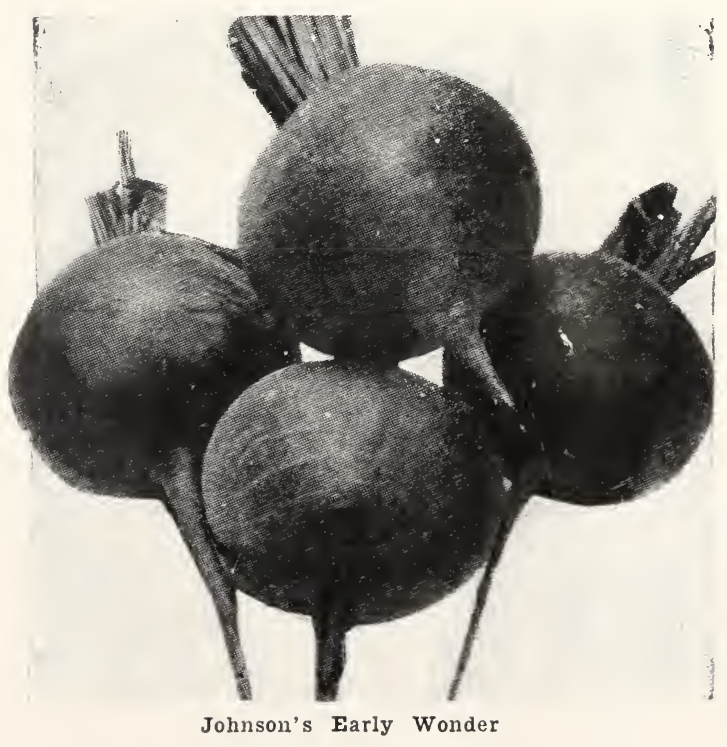

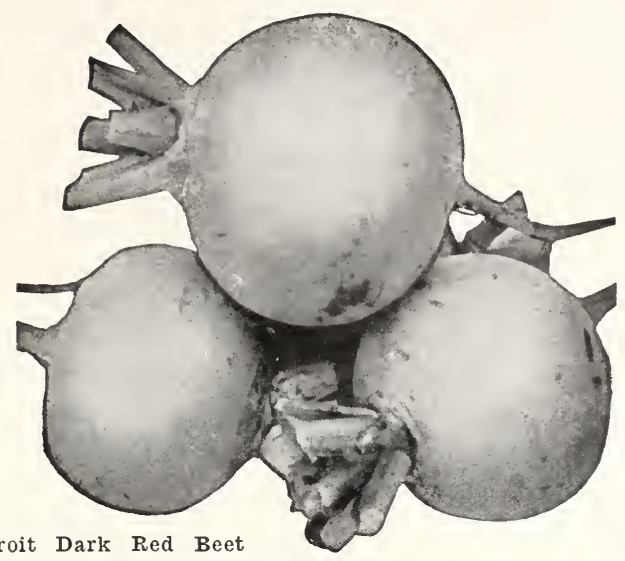

\section{Mangel-Wurzels}

Golden Tankard, Io lbs., $\$ 4.25$ 1/4 lb. Lb. $5 \mathrm{lbs}$

$\begin{array}{llll}\text { Golden Giant Intermediate } & .20 & .45 & 2.00\end{array}$

Giant Half-Sugar White .... $.20 \quad .40 \quad 1.75$

Giant Half-Sugar Rose ...... $\quad .20 \quad .50 \quad 2.25$

Mammoth Long Red,

Io lbs., $\$ 4.50 \ldots \ldots \ldots \ldots \ldots . .20 \quad .55 \quad 2.50$

Yellow or Orange Globe .... $\quad .20 \quad .50 \quad 2.00$

Special prices on large lots of Beets or Mangel-Wurzels.

\section{BRUSSELS SPROUTS}

PRIDE OF DENMARK-A fine variety, growing about 3 feet tall. Sprouts develop along entire stock at one time. Oz., $25 \mathrm{c} ; 1 / 4 \mathrm{lb}$, $75 \mathrm{c} ; 1 \mathrm{~b} ., \$ 2.50$.

Long Island Improved Dwarf-1/2 oz., 30c; oz., $55^{c} ; 1 / 4$ lb., \$I.20; lb., \$4.00.

\section{BROCCOLI}

Closely allied to the Cauliflower. It is generally considered rather more hardy. In growing Broccoli, a seedbed should be prepared and the seed sown in May. The plants will be ready to transplant late in June or early in July, and should be set in very rich, mellow ground, in rows about $2 \frac{1}{2}$ feet apart, learing I 8 inches between the plants.

ITALIAN GREEN SPROUTING-This is a distinct variety grown by Italian market-gardeners for Italian trade only. The plant forms a large, solid head which remains green. After this head is cut out, a number of sprouts develop from the leaf-axes, each sprout terminating in a small head about one inch in diameter. Bunched and sold as a second crop. Sow seed in frames early in spring and market in June and July. $1 / 2$ oz., $45 \mathrm{C} ; 0 z ., 75 \mathrm{C} ; 1 / 4$ lb., $\$ 2.00$. Postpaid.

LARGE WHITE FRENCH-Vigorous, hardy and easily grown. Heads white, compact and firm. $1 / 2$ oz., $25 \mathrm{c}$; oz., $45 \mathrm{c}$; $1 / 4$ lb., \$1.65. Postpaid. 


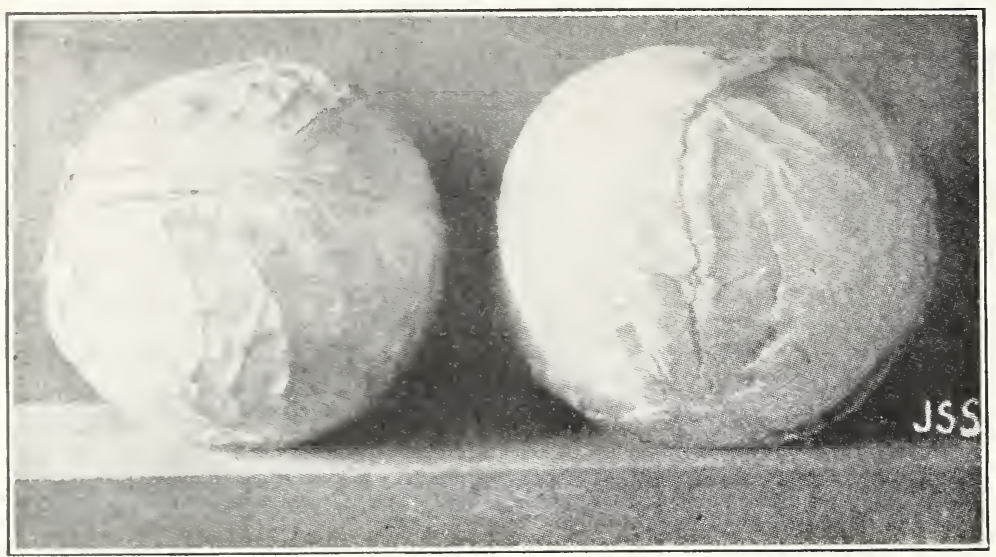

\section{Savoy Cabbage}

P E R F C T I O N DRUMHEAD - This is the hardest heading, most satisfactory, and best all-round Savoy Cabbage. $1 / 2$ oz., I 5 c; oz., 25c; 1/4 lb., 75c; lb., \$2.25. Postpaid.

Johnson's Stock Danish Ballhead Short Stem Cabbage

\section{CABBAGE}

COPENHAGEN MARKET-The round, solid heads weigh 8 to Io pounds, are of fine quality and very uniform. The light green leaves fold tightly and compactly over one another. Plants are short-stemmed, with heads just above the ground. Almost as early as Early Jersey Wakefield. Can be planted as close as Charleston Wakefield. $1 / 2$ oz., I5c; oz., 25c; $1 / 4$ lb., $75 \mathrm{c}$; lb., \$2.50. Postpaid.

GOLDEN ACRE (SPECIAL)-An early variety which closely resembles Copenhagen Market in type. As its name implies, it is a moneymaker. It is 8 to Io days earlier than Copenhagen Market but is smaller and can be planted closer. Because of its earliness and the fine quality it commands a higher price than any round-headed Cabbage. $1 / 2$ oz., 30c; oz., 50c; $1 / 4$ lb., \$I.45; lb., \$4.75. Postpaid.

\section{DANISH BALLHEAD, SHORT STEM-}

The leading late variety in many sections, and a fine sauerkraut cabbage. Heads average ten to twelve pounds, are round, fine keepers. The strong. growth and its good quality make it a most valuable cabbage. $1 / 2$ oz., 20c; oz., 3oc; $1 / 4$ lb., $85 \mathrm{c}$; lb., \$3.00. Postpaid.

HOLLANDER (Yellows-resistant)-This is a strain of Hollander or Danish Ballhead, which originated in Wisconsin where the disease known as "yellows" is very destructive. It should be used where this disease is prevalent. The type and manner of growth is not quite so good, however, as the standard sort. $1 / 2 \mathrm{oz}$., 30c; oz., 50c; 1/4 lb., \$I.50; lb., \$5.25.

GLORY OF ENKHUIZEN-Cabbage produces fine round, medium-sized heads. Very solid, with few outer leaves; tender and of fine flavor. Plants set out in mid-summer will produce fine heads before cold weather. $1 / 2$ oz., I5c; oz., 30c; 1/4 lb., 75c; lb., \$2.50. Postpaid.

\section{Chinese Cabbage}

Chihili

$1 / 2$ oz. Oz. $1 / 4$ lb. Lb.

Wong Bok

$.20 \quad .35$ I.I5 4.00

$\begin{array}{llll}.15 & .30 \quad .90 \quad 3.00\end{array}$

\section{OTHER POPULAR VARIETIES}

Allhead Early $1 / 2$ oz. Oz. $1 / 4$ lb. $1 \mathrm{~b}$.

Allhead Early (Yellow Resistant) $\ldots \ldots \ldots \ldots \ldots \ldots . \quad .20 \quad .35 \quad .95 \quad 3.50$

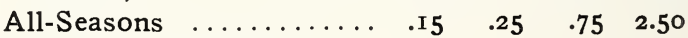

All-Seasons (Yellows

Resistant) ........... .I5 $\quad .35 \quad .95 \quad 3.50$

Early Dwarf Flat Dutch $\begin{array}{lllll}. \text { I5 } & .20 & .65 & 2.00\end{array}$

$\begin{array}{llllll}\text { Early Winingstadt } \ldots \ldots & .15 & .25 & .75 & 2.50\end{array}$

Henderson's Early

Summer ........... .I5 $\quad .25 \quad .75 \quad 2.50$

American Ballhead ..... $.20 \quad .30 \quad .85 \quad 3.00$

$\begin{array}{llllll}\text { Premium Flat Dutch } \ldots . . . & .15 & .25 & .70 & 2.25\end{array}$

Surehead ............. .I5 $\quad .25 \quad .75 \quad 2.50$

$\begin{array}{llllll}\text { Succession } \ldots \ldots \ldots \ldots \ldots & .15 & .25 & .75 & 2.50\end{array}$

\section{Red Cabbage}

$1 / 2$ oz. Oz. 1/4 lb. Lb.

Mammoth Rock Red ... \$0.I5 \$0.30 \$0.90 \$3.00 Hollander Red ..........40 $\quad .75 \quad 2.75$ 10.00 Danish Stonehead Red ...

\section{CHICORY}

WITLOOF SELECTED FORCING-This selected strain can be forced easily and produces beautiful, solid, crisp, pure white heads. The forcing of Chicory is becoming popular with gardeners. Oz., 40c; $1 / 4$ lb., \$I.20; lb., \$4.0o.

Witloof (French Endive) Oz. 1/4 lb. Lb.

COLLARDS

True Southern or Georgia

5 lbs., $\$ 4.50 \quad .5_{5} \quad .35 \quad$ I.20

CORN SALAD

Large leaved ............ .I5 $\quad .35 \quad$ I.25

CRESS

Extra Fine Curled ............ 5 .30 $\quad .85$

Upland $\ldots \ldots \ldots \ldots \ldots \ldots \ldots \ldots \ldots$.I5 $\quad .35 \quad 1.25$

Water Cress $\ldots \ldots \ldots \ldots \ldots \ldots \ldots . .50 \quad$ I.30 4.00

HOTKAPS-Try some Hotkaps to protect your early plants from frost wind, rain and insects. Thousands of them are being used by large growers. They are offered on page 20. 


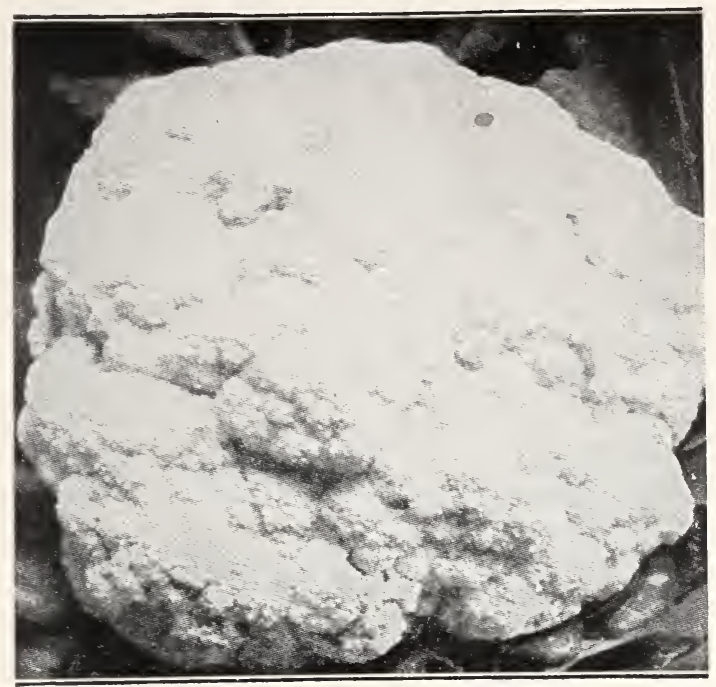

Super Snowball

\section{Semesan Controls Damping Off}

Apply in dust or liquid form to seed before planting. Destroys disease organisms that may be on seed without harming seed. 2 ozs., 5oc; lb., \$2.75.

\section{CAULIFLOWER}

JOHNSON'S GILT EDGE EARLY SNOWBALL-One of the best types of Cauliflower on the market. Its compact habit of growth renders it profitable to force under glass, and it does well for late planting. Our stock is from the best Danish grower. It is a sure header. Pkt., 25c; 1/4 oz., 6oc; $1 / 2$ oz., \$I.I5; oz., \$2.00; 1/4 lb., \$7.50; lb., \$25.00.

SUPER SNOWBALL-A promising new strain. It deserves a trial. Pkt., 25c; 1/4 oz., $80 c ; 1 / 2$ oz., \$1.50; oz., \$2.75.

Dry Weather-1/4 oz., $65^{\mathrm{c}}$; $1 / 2$ oz., \$1.25; oz., \$2.00; $1 / 4$ lb., \$7.00; lb., \$25.00.

Extra-Early Dwarf Erfurt $-1 / 4$ oz., 6oc; $1 / 2$ oz., \$I.I5; oz., $\$ 2.00 ; 1 / 4$ lb., $\$ 7.00$; lb., $\$ 25.00$.

JOHNSON'S EARLIES T SNOWSTORMSnowstorm is the very best and earliest strain of Canliflower on the market for iorcing. It is a dwarf variety, with short outer leaves, and can be planted close. 2 feet apart each way. It always makes a fine, large and exceedingly beautiful snowy whit e head, much earlier than any other variety. Pkt., $25 \mathrm{C} ; 1 / 4 \quad$ oz., $85 \mathrm{C} ; 1 / 2$ oz., \$1.6o; oz., \$3.0o. Postpaid.

\section{CARROT}

One ounce will sow Ioo feet of row; 3 pounds will sow an acre.

DANVERS HALF-LONG-The best for general crop as it will yield the most per acre. Profitable for market gardeners. Tops medium size; roots orange, large, but of medium length, tapering uniformly to a blunt point. Smooth and handsome. Oz., Ioc; 1/4 lb., 30c; lb., \$1.00; 5 lbs., \$4.25; Io lbs., \$7.50.

NANTES HALF-LONG-Early. Sweet and fine-flavored; almost without a core; very finegrained. One of the finest in quality and handsomest of the medium-sized sorts; about 6 ins. long. A few days earlier than Chantenay. Oz., Ioc; $1 / 4$ lb., 30c; lb., \$I.00; I0 lbs., \$9.00.

OXHEART-Intermediate in length; 3 to 5 inches in diameter; quality extra good. Some sorts require digging but the Oxheart can be pulled. It is especially adapted to shallow soils. Oz., Ioc; $1 / 4$ lb., 30c; lb., \$I.00; Io lbs., \$9.00.

IMPROVED CHANTENAY - A popular and profitable early sort to raise for city markets. It is about 6 inches long, thick through, and decidedly stump-rooted. The flesh is a deep orange, fine-grained and of splendid flavor. It is very early and always produces smooth, shapely roots. Outsells any other variety. Oz., IOc; $1 / 4$ lb., 30c; lb., 9oc; 5 lbs., $\$ 4.25$; 10 lbs., \$8.oo. Postpaid.

Hutchinson

Improved Long Orange ...... . .10 .30 1.00

Large White Belgian ........ . . 10 .20 $\quad .60$

Johnson's New Early Coreless .I5 $\quad .35 \quad \begin{array}{ll}\text { I.25 }\end{array}$

Ask for prices on larger quantities of Carrots.

\section{FROM A PLEASED CUSTOMER}

For several years I have planted your Chantenay Carrot seed and find your stock is the truest I have ever used.

All Seeds offered on this page are postpaid

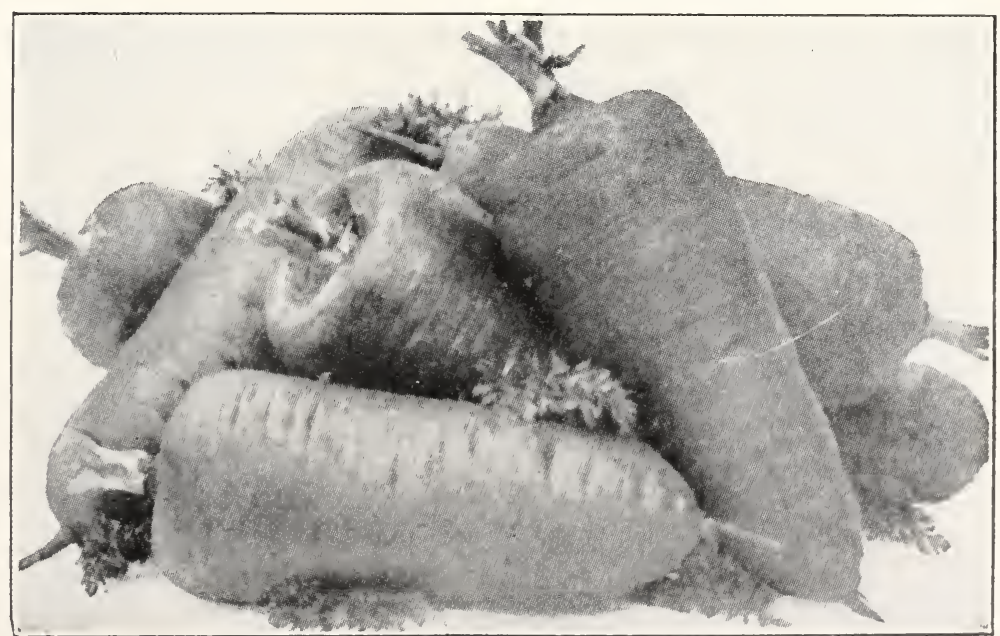

Johnsun's Improved Chantenay 


\section{CELER Y}

One ounce of seed will produce 3,000 plants; $1 / 4$ pound will plant an acre.

GOLDEN PLUME-This is a selected strain of Golden Self-blanching, having a beautiful golden color and that rich, nutty flavor so much desired by lovers of fine Celery. It resists blight and rust to a remarkable degree, matures quite early, and keeps a long time. The Golden Plume is a mighty good shipping sort. It grows to large size and of fine proportions. A very attractive sort, hence an easy one to sell. Pkt., 25c; $1 / 2$ oz., 6oc; oz., \$1.00; $1 / 4$ lb., \$3.8o, postpaid.

GOLDEN SELF-BLANCHING-Of French origin. Heavy, compact plants that grow to good size. It is very tender, solid, crisp, heart large, of excellent quality and beautiful golden color.

American-Grown Seed-A splendid strain. $1 / 2$ oz., 20c; oz., 35c; 1/4 lb., \$I.IO; lb., \$4.00. Postpaid.

French-grown Seed-From one of the most careful growers. New strain. Early. Pkt., I5c; $1 / 4$ oz., 30c; $1 / 2$ oz., 50c; oz., 90c; 1/4 lb., \$3.20; lb., \$II.50. Postpaid.

GIANT PASCAL-Forms solid, crisp stalks of rich, nutty flavor. It is of strong growth, blanches easily to a rich creamy white, and is very brittle. A fine keeper for midwinter use, retaining color and fresh appearance a long time. A favorite for local markets and private use. Pkt., IOc; 1/2 oz., 25c; oz., 40c; 1/4 lb., \$1.30; lb., \$4.50. Postpaid.

EXTRA SELECT GIANT PASCAL-French grown. Pkt., 25C; $1 / 4$ oz., 65C; $1 / 2$ oz., \$I.25; oz., $\$ 2.35 ; 1 / 4$ lb., \$8.50; lb., \$I6.00. Postpaid.

Columbia

$1 / 2$ oz. Oz. $1 / 4 \mathrm{lb}$. Lb.

Emperor $\$ 0.30$ \$0.50 \$1.50 \$5.00

Wonderful $\begin{array}{llll}.30 & .50 & 1.50 & 5.00\end{array}$

Easy-Blanching

White Plume

Winter Queen

$\begin{array}{llll}.75 & \mathrm{I} .25 & 4.25 & \mathrm{I} 5.00\end{array}$

$\begin{array}{llll}.35 & .60 & 1.75 & 5.50\end{array}$

$\begin{array}{llll}.20 & .30 & .85 & 3.00\end{array}$

$\begin{array}{llll}.25 & .40 & \mathrm{I} .25 & 4.50\end{array}$

\section{CELERIAC}

(Turnip-rooted Celery)

GIANT SMOOTH PRAGUE-Pkt., IOc; $1 / 2$ oz., 20c; oz., 30c; 1/4 lb., 8oc; lb., \$2.90. Postpaid.

\section{A Few of Our Satisfied Customers Write Us As Follows-}

I am sending you my order. I was very much pleased with my last year seeds. The Bender Surprise Melons were the best Melons I had raised in years and I hope they will be as good this year.-Phil. Pocket, Wayne County, Mich.

The seed from you for 1928 and 1929 were very satisfactory.-Mr. F. M. Houseman, Shelby County, Ohio.

Your seeds were all satisfactory, the only difficulty I guess was the weather here, but we had a good year. Received your catalogue O. K.-M. M. Johnson, Macomb County. Mich.

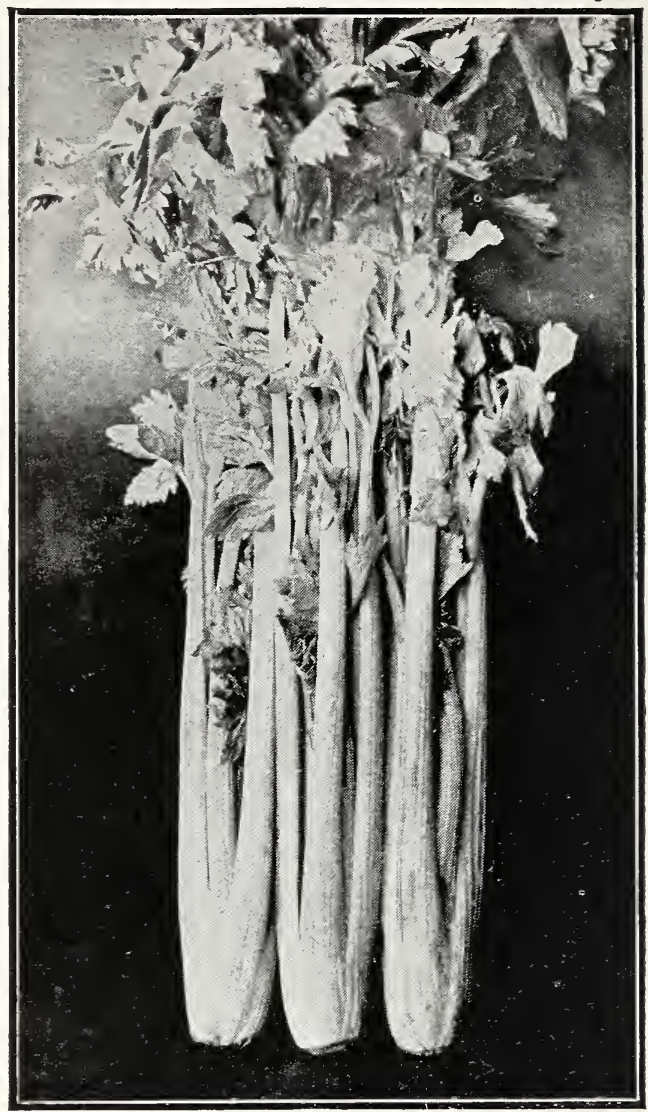

Golden Self Blanching

\section{SOME OF OUR LEADERS}

Every gardener should plant a quantity of the following varieties, all of which are money makers. You will find description on page 2. BEETS, Johnson's Early Wonder.

BROCCOLI, Johnson's "Cleveland Market."

CABBAGE, Select Golden Acre.

CARROT, Select Chantenay.

CELERY, Johnson's Golden Plume.

CORN, Johnson's Golden Standard.

LETTUCE, Johnson's Big Boston.

MUSKMELON, Bender's Surprise.

ONION, Johnson's Selected Ohio Yellow Globe. PEAS, Laxtonian.

PEPPER, California Wonder.

TOMATO, Johnson's Select Earliana.

TURNIP, Purple Top White Globe.

\section{ROADSIDE GARDENS}

Many of our customers report large increases in their incomes by systematically developing the sale of Flowers and Vegetables on their property, especially if located on a main traveled road.

Flowers are very profitable, especially Gladiolas blooms. The small cost of seed and the much lower price of Gladioii bulbs this year is surely an inducement to increase your income. Try this plan this year if you are not already doing so. 


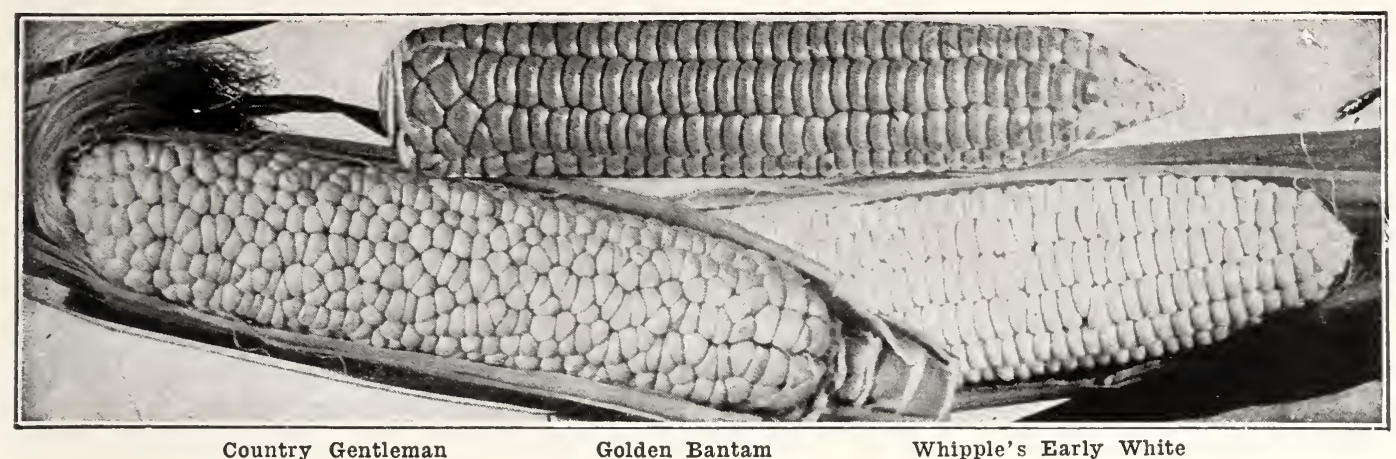

\section{SUGAR OR SWEET CORN}

One pound will plant about 200 hills; I2 pounds will plant an acre.

\section{Yellow or Golden Sweet Corns}

GOLDEN SUNSHINE-This new variety originated in North Dakota and necessarily must be extra early to mature in the short seasons in that state. It is ready for market a week sooner than Golden Bantam, has the same length of ear, but 12 rows of grains instead of 8 , and in quality and color is equal to Bantam. A successful competitor of the extra-early white vari-

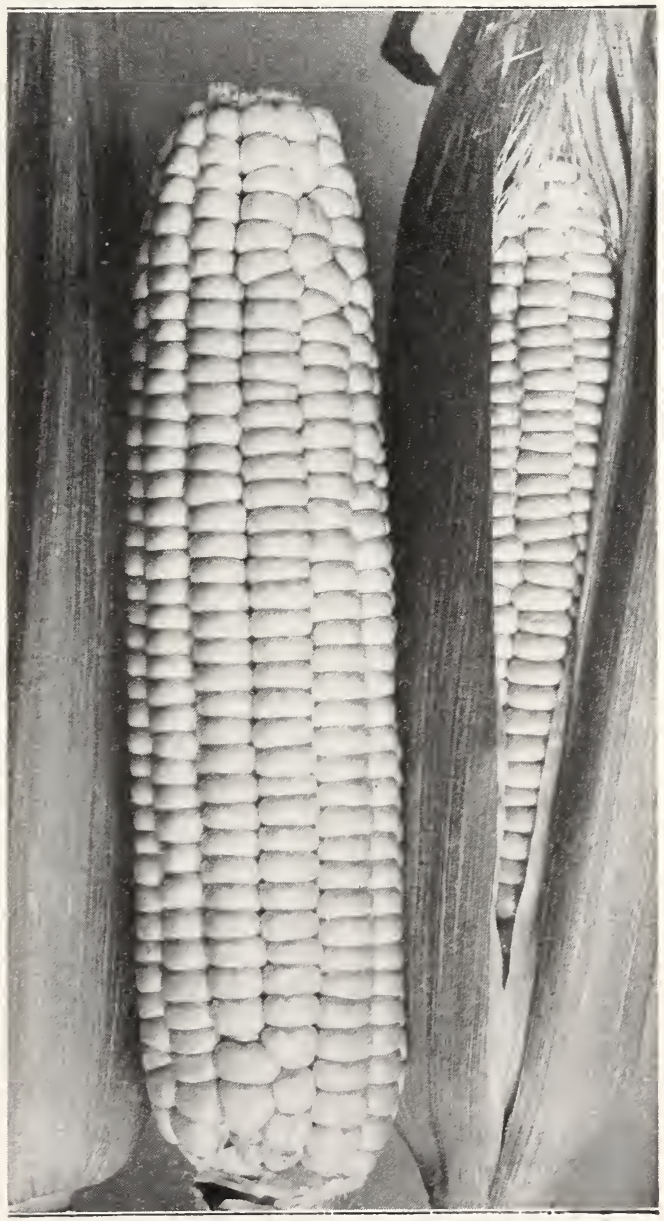

Johnson's Golden Sunshine eties. 2 lbs., 50c; 6 lbs., $\$$ I.40; I2 lbs., $\$ 2.50$; 48 lbs., \$9.0o.

WHIPPLE'S EARLY YELLOW-About double the size of Golden Bantam and only three to five days later. It is of the same fine quality. The ear is 7 to 8 inches long and carries i2 to I6 rows of deep golden kernels. Stalks are quite tall and often produce two ears. 2 lbs., 50c; 6 lbs., \$I.20; I2 lbs., \$2.00; 48 lbs., \$7.50.

BARDEN'S WONDER BANTAM-Of the same type, season and quality as Golden Bantam, but having a longer ear. The stalks grow from 5 to 6 feet high and have ears 8 to IO inches long, filled with 8 rows of rich golden kernels. Originator's stock. Lb., 30c; 2 lbs., 50c; 6 lbs., \$I.35; I2 lbs., $\$ 2.50$; 48 lbs., \$9.00. JOHNSON'S NEW GOLDEN STANDARD -This new sort is very similar to De Lue's Golden Giant and we recommend it very high1y. Makes a fine succession for Golden Bantam. Lb., 30c; 2 lbs., 50c; 6 lbs., \$1.30; I2 lbs., \$2.30; 48 lbs., \$9.00.

GOLDEN BANTAM-Produces ears measuring about 5 inches. By all odds the finest extra early variety when quality is considered. $\mathrm{Lb}$. $30 c ; 2$ lbs., 50c; 6 lbs., \$1.20; I 2 lbs., $\$ 2.00 ; 48$ lbs., $\$ 7.50$.

BANTAM EVERGREEN-A golden Ever. green. Has the good qualities of Golden Bantam combined with those of the Evergreen. Comes just right in season to follow the early sorts. Color a rich golden yellow. Ears about 8 inches long and 2 inches thick. Lb., $35 \mathrm{c}: 2$ lbs., 6oc; 6 lbs., \$1.40; I2 lbs., $\$ 2.40 ; 48$ lbs., $\$ 9.00$.

\section{White Varieties}

EARLIEST MAYFLOWER-This is a ten to twelve-rowed corn, larger than Mammoth White Cory and from three to five days earlier. Three seasons' trials of this splendid sort have convinced us that it is the coming extra early corn. Lb., 30c; 2 lbs., 50c; 6 lbs., \$1.30; I2 lbs., $\$ 2.35 ; 48$ lbs., $\$ 8.50$.

WHIPPLE'S EARLY WHITE-One of the Evergreen type, but ready for use only a few days later than the Golden Bantam. Ears 7 to 8 inches long with I 2 to I6 rows of pearly white grains. The earliest of the deep-grained Evergreen types and has the same delicious sweetness. 2 lbs., 50c; 6 lbs., \$I.20; I2 lbs., $\$ 2.00$; 48 lbs., $\$ 7.25$. 


\section{OTHER STANDARD SWEET CORNS}

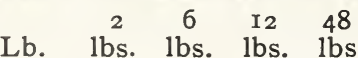

Alpha, extra early. \$0.30 \$o.50 \$1.20 \$2.00 \$7.50

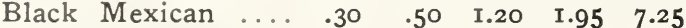

$\begin{array}{llllll}\text { Columbus Market. } & .30 & .50 & \text { I.20 } & 1.95 & 7.50\end{array}$

$\begin{array}{llllll}\text { Country Gentleman } & .40 & .70 & 1.50 & 2.50 & 9.25\end{array}$

Extra-Early Adams $.30 \quad .50$ 1.00 $1.80 \quad 6.00$

Early Adams ..... $.30 \quad .50 \quad$ I.00 $\quad 1.75 \quad 5.75$

Early Evergreen .. $\quad .35 \quad .60 \quad 1.40 \quad 2.65 \quad 9.00$

Howling Mob ..... $.30 \quad .50 \quad$ I.25 $\quad 2.30 \quad 8.75$

$\begin{array}{llllll}\text { Kendel's Early Giant } & .30 & .50 & \mathbf{1} .25 & 2.30 & 8.50\end{array}$

Mammoth Late

Sugar

Mammoth White

Cory

Stowell's Evergre

\section{EGGPLANT}

One ounce will produce about $\mathrm{I}, 000$ plants; $1 / 4$ pound will sow an acre.

JOHNSON'S LONG PURPLE TOKYOExtra early, surprisingly prolific, quality splendicl. Size about 7 inches long and 2 inches in diameter. $1 / 2$ oz., 40c; oz., 65c; 1/4 lb., \$2.0o, postpaid.

EARLY BLACK BEAUTY-From ten days to two weeks earlier than the purple varieties, and of rich lustrous purplish black color. The plants are remarkably healthy, and yield an abundance of large fruits. Entirely spineless. $1 / 2 \mathrm{oz}$. 25c; oz., 40c; 1/4 lb., \$I.25; lb., \$4.40, postpaid. IMPROVED NEW YORK PURPLE-Very solid, of rich shining deep purple color. $1 / 2$ oz. 25c; oz., 40c; $1 / 4$ lb., \$r.25; lb., \$4.40, postpaid.

\section{POP CORN}

Tom Thumb or Japanese

Lb. 3 lbs. 5 lbs. Io lbs.

Hulless $\ldots \ldots \ldots \ldots \ldots \$ 0.20$
\$0.55

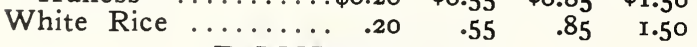

\section{DANDELION}

$1 / 2$ oz. Oz. $1 / 4$ lb. Lb.

Large-leaved French... \$o.40 \$o.75 \$2.75 \$10.00 Common ..............30 $.55 \quad 1.65 \quad 5.00$ Above prices postpaid.

\section{DILL}

COMMON-Oz., roc; $1 / 4$ lb., I5c; lb., 50c. Postpaid.

LONG ISLAND MAMMOTH-Similar to above except larger plant and seedheads. Oz., I5c; 1/4 lb., 25c; lb., 65c. Postpaid.

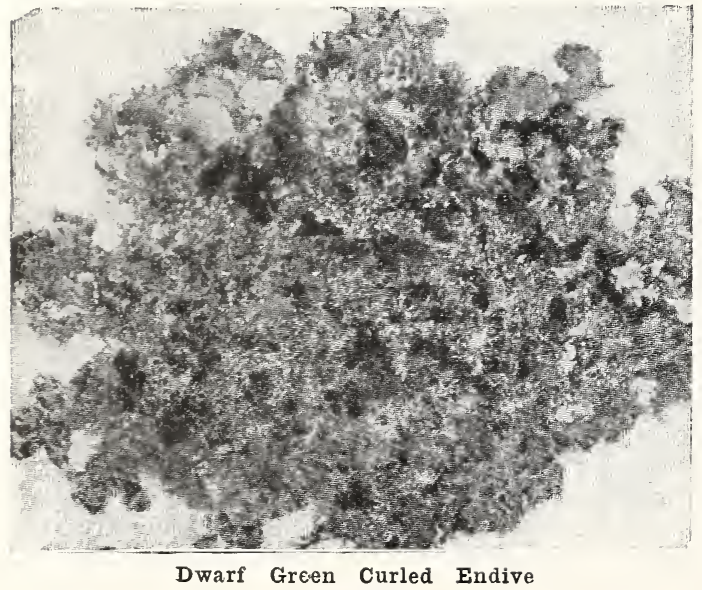

\section{FENNEL}

FLORENCE-A bulb-like vegetable which is formed above the ground at the base of the leaf-stalk, if the plant is well grown. Blanched and boiled it has a slightly aromatic odor and pleasant taste. Plant very branching, upright, with dense thread-like foliage. Oz., 2oc; 1/4 lb., 6oc; lb., \$2.00. Postpaid.

\section{GARLIC}

Sets-1/4 lb., roc; lb., 35c; 5 lbs., \$1.25.

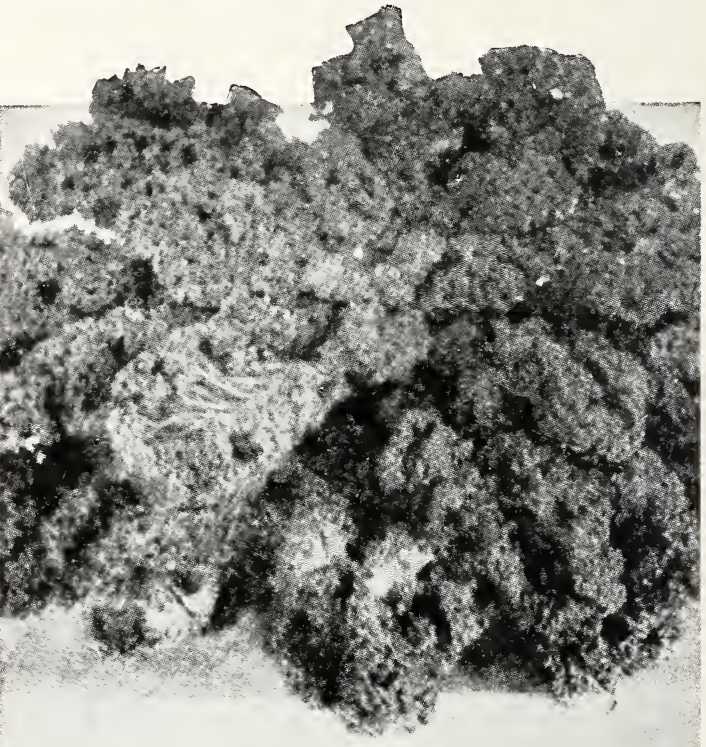

Dwarf Green Curled Kale

HERBS

\begin{tabular}{|c|c|c|c|}
\hline way & Oz. & $\begin{array}{l}1 / 4 \mathrm{lb} . \\
\$ 0.15\end{array}$ & $\begin{array}{c}\text { Lb. } \\
\$ 0.50\end{array}$ \\
\hline Coriander & 01. & .I5 & \\
\hline Fennel, Sweet & .15 & .35 & \\
\hline Horehound . . & .25 & .75 & \\
\hline Lavender, Sweet & .15 & .50 & \\
\hline Sage, Broad-leaved & .15 & .45 & \\
\hline Summer Savory ... & .15 & .35 & \\
\hline$\ldots \ldots \ldots \ldots$ & .15 & .45 & \\
\hline et Marjoram $\cdot 1 / 2$ oz., Ioc & .15 & .50 & \\
\hline Thyme $\ldots \ldots \ldots 1 / 2$ oz., $20 c$ & .30 & .85 & \\
\hline
\end{tabular}
All Herbs are Postpaid.

\section{ENDIVE}

LARGE GREEN CURLED-A hardy, vigorous growing variety with bright deep green leaves. Center blanches very readily to rich creamy white. Oz., I5c; 1/4 lb., 45c; lb., \$I.3O. Broad-leaved Batavian Oz. 1/4 lb. Lb. (Escarolle) $\ldots \ldots \ldots \ldots \ldots . \$ 0.15 \quad \$ 0.35$ \$1.25 Fine Green Curled ........ . .15 .35 1.25

\section{KALE}

DWARF GREEN CURLED or SCOTCHVery dwarf and spreading, with leaves beautifully curled and of a bright green color. Quite hardy. Oz., roc; 1/4 lb., 25c; lb., 75c. Postpaid. SIBERIAN-Dwarf growth; bluish green leaves. Very hardy and makes excellent spring greens. Oz., roc; 1/4 lb., 20c; lb., 65c; 5 lbs., $\$ 2.70$; ro lbs., $\$ 5.00$ Postpaid. 


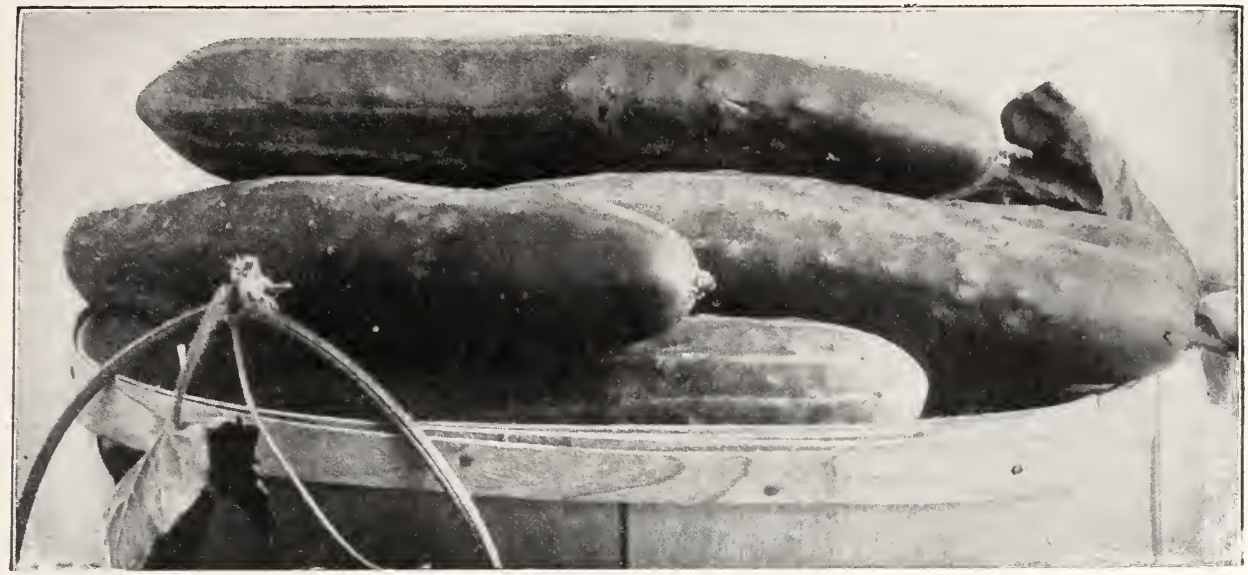

Johnson's Selected Davis Perfect Cucumber

\section{CUCUMBERS}

One ounce will plant 50 hills; 2 pounds will plant an acre in hills, 5 pounds in drills.

JOHNSON'S FIRST IN MARKET-For over thirty years we have been selecting and breeding up this type of extra early White Spine-the object being to get perfect fruits of "slicing" size into the market at earliest possible date. The color is an attractive dark green. The vines

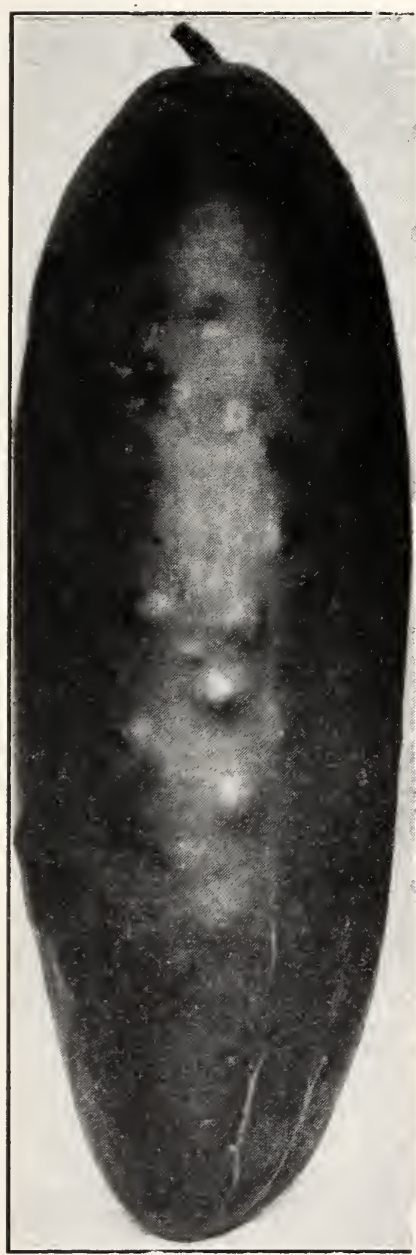

Johnson's Perfect White Spine are of vigorous growth and produce abundantly, making them most profitable, both for the earliest "slicers" and when planted in June or July for pickles. When ready for slicing they run from 6 to 8 inches long, very straight and full and tapering abruptly at both ends. Oz., roc; $1 / 4$ lb., 30c; lb., \$r.0o; 5 lbs., \$4.65. Postpaid.

JOHNSON'S SELECTED DAVIS PERFECT-We have spent many years in working up a very fine strain of Davis Perfect in which fine length, slimness, beautiful dark green color are distinguishing features of this most popular of the extra long white spine cucumber. For indoor and outdoor planting it is most popular. Its extremely vigorous growth makes it the best blight resister of the long sorts. Oz., I5c; 1/4 lb., 35c; lb., \$I.I0; 5 lbs., \$5.00; I0 lbs., \$9.oo. Postpaid.

JOHNSON'S PERFECT WHITE SPINE-The finest type of White Spine yet produced. Early very productive and disease-resistant; fruits nine inches long, slightly tapering; flesh white, very firm and crisp, with very few seeds; color rich, dark green, which does not fade when shipped a long distance. See cut at left. Oz., I5c; 1/4 lb., 35c; lb., \$I.25; 5 lbs., \$5.50; ro lbs., \$10.00. Postpaid.

BOSTON PICKLING or GREEN PROLIFIC - Fruit short, smooth, symmetrical and bright green; very productive, making a good pickle; a little shorter and thicker than most pickling sorts. Oz., I0c; 1/4 lb., 30c; lb., 95c; 5 lbs., \$4.50; Io lbs., \$8.00. Postpaid.

IMPROVED LONG GREEN-A standard late, well known table sort; I 2 to I4 inches long, slender, more or less warted, tapering towards the stem end; color dark green, flesh white and firm. We have a superior stock of this variety. Oz., I5c; 1/4 lb., 35c; lb., \$I.20; 5 lbs., \$5.50; ro lbs., \$10.50. Postpaid.

EARLY FORTUNE-A very fine strain of White Spine. It is early and very productive, excellent for market and pickles. The fruit is 8 to 9 inches long, slightly tapering and of deep green color. It holds its color well when shipped. Oz., Ioc; 1/4 lb., 30c; lb., \$1.00; 5 lbs., \$4.65; ro lbs., \$9.0o. Postpaid.

Prices Postpaid Oz. 1/4 lb. Lb. $5 \mathrm{lbs}$. Arlington Improved White Spine .......\$o.ro \$o.30 \$0.95 \$4.50 Chicago Pickling or Westerfield .......... . . I0 $\quad .30 \quad .95 \quad 4.50$ Early Green Cluster .................. .10 .30 $\quad .95 \quad 4.50$ Extra Long or Evergreen White Spine .. Jersey Pickling ................... .10 .30 $.95 \quad 4.50$ Klondyke White Spine ............... .10 .30 .95 4.50 Gherkin or Burr ................ . $55 \quad .35$ J.20 


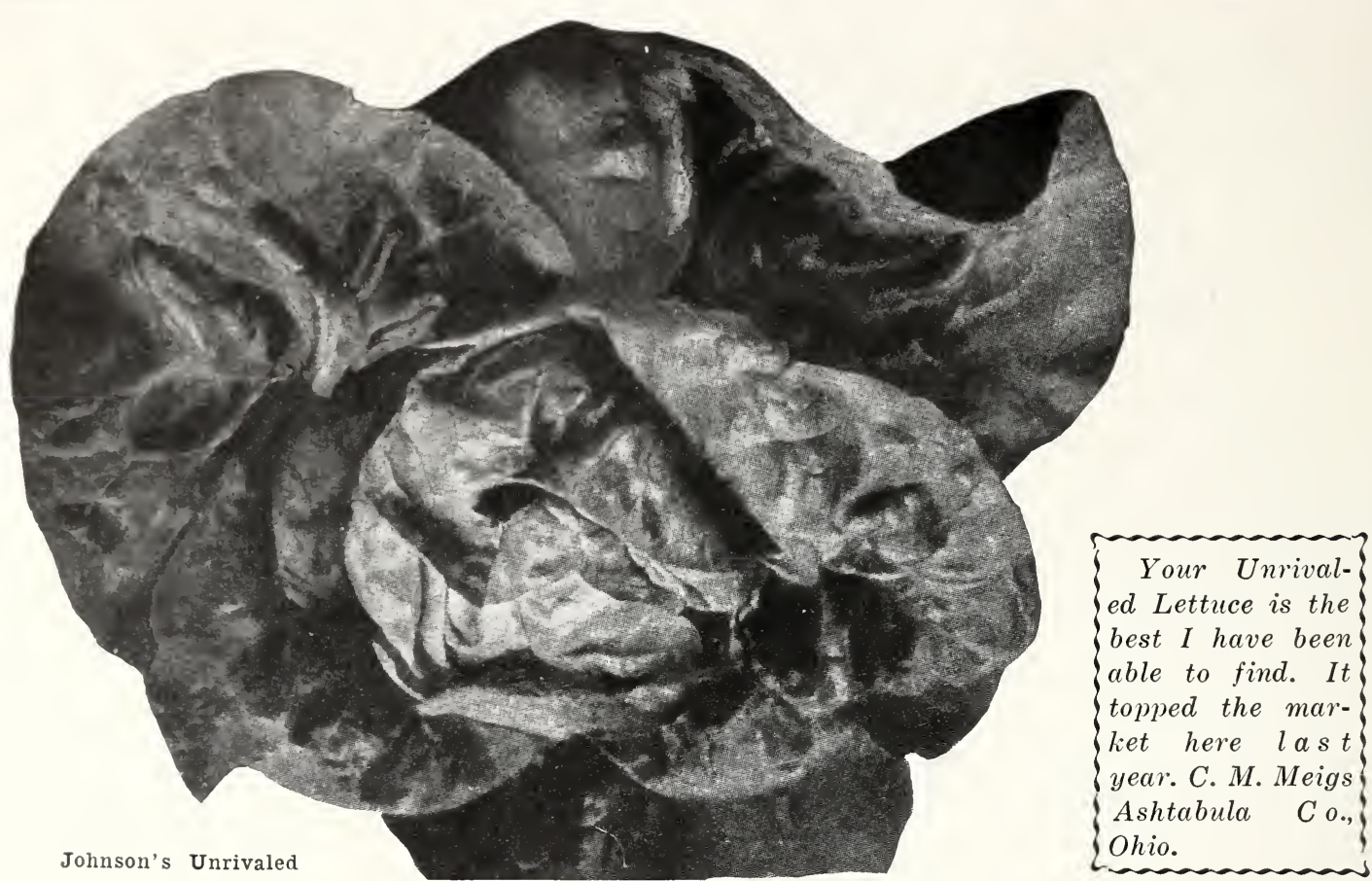

\section{LETTUCE}

ALL HEART-This is the most reliable hardheading lettuce ever introduced withstanding intense heat and forming magnificent heads even before it is half grown. Oz., I5c; $1 / 4 \mathrm{lb}$., 45c; lb., \$I.50; 5 lbs., \$7.20. Postpaid.

BIG BOSTON-(Selected Stock) Very popular for outside culture as well as cold frame forcing. Head large and compact; leaves broad, almost smooth, but wavy at the edge; color light green slightly tinged reddish brown; heart greenish white, tinged yellow. Oz., I5c; 1/4 lb., 45c; lb., \$I.50; 5 lbs., \$7.20. Postpaid.

UNRIVALED-An improvement on the Whiteseeded Big Boston, forming very solid, large, pale green heads of excellent quality, without the reddish brown tinge. Forms a head in about 6 weeks and is earlier than the regular Big Boston. May be sown all through the year and stands heat remarkably well; it is also a very fine forcer. Is crisp, solid and a good shipper. Originator's French-grown Seed, oz. 20c; 1/4 lb., 70c; lb., \$2.50. Best American grown, oz., I5c; 1/4 lb., 45c; lb., \$I.50; 5 lbs. \$7.20. Postpaid.

GRAND RAPIDS (Johnson's Special Forcing Strain)_The favorite loose-leaved forcing lettuce and does well in the North for early planting outside. Leaves blistered and crumpled, and the border heavily fringed; color light green, with no trace of brown. A most handsome and attractive lettuce of fair quality. Our stock of Grand Rapids is very specially selected. Oz., I5c; 1/4 lb., 45c; lb., \$1.50. Postpaid.

OHIO GRAND RAPIDS-This strain is distinguished by being darker in color than the original strain. It has proved wonderfully superior for planting during the darker months of the year. It thrives during cloudy weather and makes a much heavier growth than the lighter colored strain; and is being used extensively by greenhouse men. We have the originator's strain, and highly recommended it for winter greenhouse growing. Oz., I5c; 1/4 lb., 45c; lb., \$.50. Postpaid.

SIMPSON BLACK SEEDED-One of the best and most popular large, early, loose-heading varieties, succeeding everywhere and always reliable. Leaves very broad, much blistered and crumpled, and excessively frilled on the borders. Color light yellowish green; quality fine. Oz., I5c; 1/4 lb., 40c; lb., \$I.25. Postpaid.

WONDERFUL-(Sometimes called New York or Los Angeles). This very large heading lettuce is desirable not only for summer use but is much used as a fall market sort. The plant is compact and tight heading; outer leaves attractive deep green, broad, frilled at edges. The inner leaves form a large head, very sweet and tender. Oz., I5c; 1/4 lb., 50c; lb., \$I.70; 5 lbs., \$8.0o. Postpaid.

ICEBERG-(W. S.) The large, white, incurving main-ribs of the leaves hold the heads well together, and consequently the heart is thoroughly blanched. Oz., I5c; 1/4 lb., 50c; lb., \$I.50; 5 lbs., \$7.50. Postpaid.

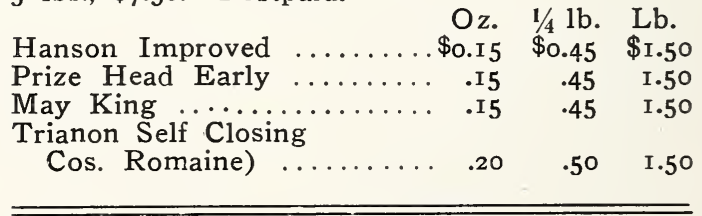

\section{LEEKS}

Broad Scotch or London Oz. $\quad 1 / 4$ lb. Lb.

Flag ..............\$0.20 \$0.55 \$I.75

Large Musselburgh ...... .20 $\quad .55 \quad$ I.75

$\begin{array}{lllll}\text { Large Rouen .............. } & .20 & .55 & 1.75\end{array}$ 


\section{MUSKMELON}

One ounce will plant 50 hills; 2 to 3 pounds will plant an acre. NEW BENDER'S SURPRISE -A new sort which is bound tc prove very profitable for market gardeners because of its unusually attractive appearance on market, its great productiveness and its unusual keeping qualities. It ripens medium early. When ready for market the outside color is creamy yellow, with light green netting. Shape just oval enough to make it carry well. Flesh deep orange, and quality is so fine that the consumers' demand is heavy. No progressive gardener should fail to try this melon. Oz., I5c; 1/4 lb., 35c; lb., $\$ 1.25 ; 5$ lbs., \$5.25. Postpaid.

OHIO SUGAR-Distinctly ribbed and well netted-color of skin gray-green. The firm flesh is an attractive green of exquisite texture, sugary, juicy, tender, and free from stringiness; seed cavity is small. Uniform shape. A market and home garden melon. Oz. I5c; 1/4 lb., 40c; lb., \$I.30; 5 lbs., \$5.75. Postpaid.

LAKE CHAMPLAIN-An exceedingly early salmon-fleshed melon of medium size and good quality. It is not entirely true as to type, but on account of its extreme earliness and quality we recommend its use for nearby markets. Give this one a trial. Oz., I5c; 1/4 lb., 35c; lb., \$1.25; 5 lbs., \$5.50. Postpaid.

SELECT OSAGE_The vines are vigorous and productive. Fruits are oval, of a medium-large size, with dark green skin, slightly ribbed and covered with shallow netting. The rich orangecolored flesh is very thick, allowing only a small seed cavity, and is highly flavored. Oz., Ioc; 1/4 lb., 35c; lb., \$I.25; 5 lbs., \$5.50. Postpaid.

EXTRA EARLY OSAGE-A week to ten days earlier than the old type Osage, and nearly as large; flesh very thick, salmon colored and of high quality. Form, color and general appearance similar to Osage. One of the very best melons we grow. Oz., I5c; 1/4 lb., 45c; lb., \$1.50; 5 lbs., \$6.25. Postpaid.

HEARTS OF GOLD-The best salmon-fleshed melon for market. Fine grained, not stringy, and of the sweetest flavor. Size and shape just right, so it may be served cut in halves. Color deep orange, flesh extremely thick. As a shipper, uniform, like "peas in a pod." Netting is ideal, heavy and close. Prolific and uniform, produces well under unfavorable conditions, and withstands blight better than most varieties. Oz., 20c; 1/4 lb., 55c; lb., \$I.90; 5 lbs., \$9.0o. Postpaid.

SELECTED TIP TOP-A very heavy-cropping, attractive melon in great demand. Fruits moderately large, nearly round, distinctly ribbed, and slightly netted, with light yellow skin when mature. Flesh deep salmon colored, thick, solid, and fine grained, of delicions quality and edible to the rind. This is a good early and main crop variety. Oz., I5c; $1 / 4$ lb., 45c; lb., \$I.50; 5 lbs., \$6.50. Postpaid.
Acme or Baltimore Nutmeg

Oz. 1/4 lb. Lb. 5 lbs.

Banana

Burrell Gem

Gold-lined Rocky Ford

Edward's Perfecto

Extra-Early Hackensack

Emerald Gem

Greely Wonder

Honey Ball

Honey Dew Green-fleshed

Honey Dew Salmon-

fleshed

Perfection

Rocky Ford

All above Postpaid.

\$o.I5 $\$ 0.35 \$ 1.25$

$\begin{array}{lll}.15 & .35 & 1.25\end{array}$

$\begin{array}{llll}.10 & .30 & 1.00 & \$ 4.75\end{array}$

$\begin{array}{lll}.15 & .35 & 1.25\end{array}$

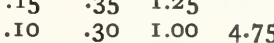

$\begin{array}{llll}.10 & .30 & 1.00 & 4.75\end{array}$

$\begin{array}{llll}.10 & .30 & 1.00 & 4.75\end{array}$

$\begin{array}{llll}.15 & .35 & \text { I.I } & 5.50\end{array}$

$\begin{array}{llll}.25 & .75 & 2.25 & 10.00\end{array}$

.10 $\quad .30 \quad 1.00 \quad 4.75$

$\begin{array}{llll}.10 & .30 & 1.00 & 4.75\end{array}$

$\begin{array}{llll}.10 & .30 & 1.00 & 4.75\end{array}$

$\begin{array}{llll}.10 & .25 & .75 & 3.50\end{array}$

\section{WATERMELONS}

COLE'S EARLY-One of the best for Northern sections. Medium size, nearly round; rind dark green; flesh deep pink. Oz., Ioc; 1/4 lb., 20c; lb., 65c; 5 lbs., \$2.75. Postpaid.

FORDHOOK EARLY - An extra early variety of fine quality and fair size; form round to oblong. Oz., IOc; 1/4 lb., 25c; lb., 70c; 5 lbs., \$3.0o. Postpaid.

KLECKLEY'S SWEETS or MONTE CRISTO-Medium to large in size, medium early and exceedingly sweet; oblong in form; rind very dark green; flesh rich red. Oz., Ioc; 1/4 lb. 20c; lb., 6oc; 5 lbs., \$2.50. Postpaid.

PHINNEY'S EARLY-Ripens with Peerless; medium in size and oblong in form; quality good. Oz., Ioc; $1 / 4$ lb., 20c; lb., 6oc; 5 lbs., \$2.50. Postpaid.

SWEETHEART-A medium early variety growing to a very large size; round to oblong form, color very light green, flesh bright red. Oz., Ioc; 1/4 lb., 20c; 1b., 6oc; 5 lbs., \$2.50. Postpaid.

\section{CITRON}

COLORADO PRESERVING-An improvement on the old Preserving Citron; seeds green, fruit round to oblong. $\mathrm{Oz}$., roc; $1 / 4 \mathrm{lb}$., $25 \mathrm{c}$; lb., 75c. Postpaid. 


\section{ONIONS}

JOHNSON'S SELECTED OHIO YELLOW GLOBE-Our seed of this finest of all Yellow Globe Onions is Ohio stock grown by expert onion men. The strain is distinguished by attractive shape and handsome bright yellow color, ripens early and all at once; neck very small, and curves down to almost nothing. The bulbs are excellent winter keepers, and all that can be desired in size and quality; enormous yielders. This is a superb onion for all classes of soil and especially good for all onion sections on account of its quick maturing qualities. Oz., 25c; $1 / 4$ lb., 7oc; lb., \$2.25; 5 lbs.2 \$II.0o. Postpaid. MAMMOTH YELLOW PRIZETAKEROne of the largest onions grown and the mildest; is productive and a sure cropper; bulbs are globe-shaped and of a light straw color. Our seed is American grown and very superior. $\mathbf{O z}$. 25c; 1/4 lb., 70c; lb., \$2.25; 5 lbs., \$II.oo. Postpaid.

YELLOW GLOBE DANVERS-This special strain is grown from carefully selected, handsorted bulbs and is superior to most stock offered under this name. Oz., I5c; 1/4 lb., 5oc; lb., \$I.75; 5 lbs., \$8.00. Postpaid.

SOUTHPORT WHITE GLOBE-Of the true Southport Globe form with a thin, delicate skin of purest paper whiteness; flesh is very crisp, fine-grained and snowy-white in color, and exceedingly mild; usually commands the highest price in market. Oz., 25c; $1 / 4$ lb., 8oc; lb., \$2.75. Postpaid.

WHITE PORTUGAL or SILVERSKIN-A large, flat white onion of mild and pleasant flavor; hard and fine-grained. The Portugal is more extensively grown for sets than any other white variety, and is also largely used as a pickler and for bunching. Oz., 25c; $1 / 4$ lb., 75c; lb., \$2.50. Postpaid.

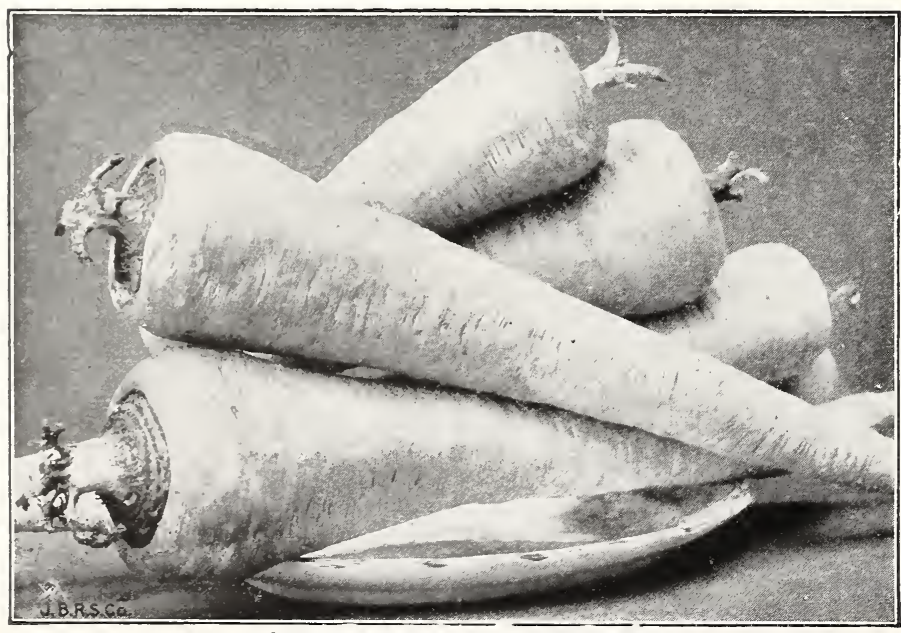

Improved Hollow Crown Parsnip
WHITE QUEEN-A rapid growing small, flat, early white onion; grown extensively for pickling and bunching. Oz., $25 \mathrm{c} ; 1 / 4 \mathrm{lb} ., 75 \mathrm{c} ; \mathrm{lb}$., \$2.50. Postpaid.

WHITE WELSH-A perennial sort which forms many small, slim Onions, used to bunch for salad. The summer crop is sown in spring. To carry over winter for spring crop, it should be sown in furrows 4 inches deep and the soil leveled up as the plants grow. Oz., 20c; 1/4 lb., $75 \mathrm{c}$; lib., \$2.25. Postpaid.

Ailsa Craig Oz. $1 / 4 \mathrm{lb} . \mathrm{Lb}$. Extra Early White Barletta... Large Red Wethersfield ...... Mammoth Silver King............25 Mountain Danvers ..............2 Southport Red Globe ........ $\begin{array}{lllll}\text { Southport Yellow Globe } \ldots \ldots & .20 & .65 & 2.00\end{array}$ Yellow Dutch or Strassburg... I5 $\quad .50$ I.75

\section{ONION SETS}

ONION SETS-White Bottom Sets, Yellow Bottom Sets and Egyptian Winter Sets. Market fluctuates. Please write for prices.

\section{PARSNIP}

IMP. HOLLOW CROWN or GUERNSEYOur stock of this variety is not quite so long as Hollow Crowned, but of greater diameter; clean skinned, with a fine, grooved neck. Oz., 10c; 1/4 lb., 25c; lb., 75c; 5 lbs., \$3.00; Io lbs., $\$ 5.50$. Ppd.

\section{MUSTARD}

FORDHOOK FANCY-A handsome vigorous growing mild variety standing a long time before going to seed; leaves dark green, beautifully curled and fringed; fine for salads and garnishings. $\mathrm{O} z$., Ioc; $1 / 4$ lb., $25 \mathrm{c}$; lb., $65 \mathrm{c}$; 5 lbs., \$3.00. Postpaid.

Southern Giant Curled-Plant vigorous and hardy, of upright spreading growth: leaves large, light green-tinged yellow, much crumpled and frilled at the edges. The popular market variety in the South. Oz., IOc; 1/4 lb., 20c; lb., $6 o c ; 5$ lbs., \$2.70. Postpaid. 


\section{GARDEN PEAS}

Two pounds of Peas equals I quart.

If only one pound of Peas is wanted order at two pound rate.

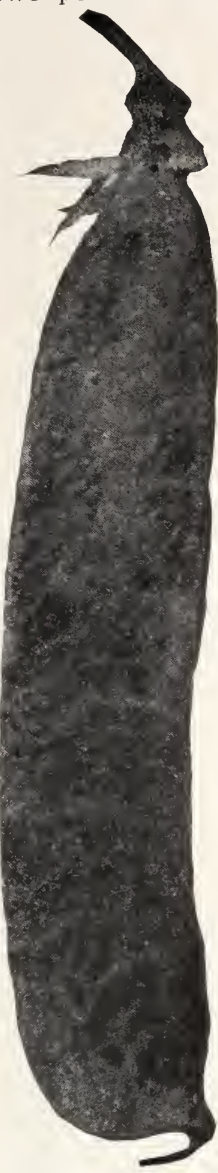

THOMAS LAXTON-( See cut). A very popular gardener's variety. Height $2 \frac{1}{2}$ feet; vine and foliage moderately stout, medium green; pods $3 \frac{1 / 4}{4}$ inches long, straight, nearly round and square ended, containing 7 medium dark green peas of superior quality. Same season as Gradus, but a trifle more productive. 2 lbs., 6oc; 7 lbs., I.5o; I4 lbs., \$2.75; 56 lbs., \$10.50.

LAXTONIAN-A large-podded variety on the order of Gradus, though more dwarf and a little earlier. Height I $1 / 2$ feet; pods and vine dark green; pods 4 inches long, straight and pointed, containing 6 to 8 large, dark green peas. 2 lbs., 6oc; 7 lbs., $\$$ I.50; I4 lbs., \$2.75; 56 lbs., \$10.50.

LITTLE MARVEL - Extra fine dwarf sweet pea. Pods somewhat larger than Nott's Excelsior and same season. A fine variety for either private or market garden. Height I4 inches. Foliage and pods very dark green. Pods 3 inches long, nearly round and squareended, containing 7 very dark green peas of high quality; very productive. 2 lbs., 6oc; 7 lbs., \$I.40; I4 lbs., \$2.50; 56 lbs., \$9.50.

ALDERMAN-Of the Telethone type but with darker pods and peas. Height 4 feet. Vine strong and stout, medium green; pods $43 / 4$ ins, long, very broad, dark green pointed, straight, though slightly curved at the point, containing 9 large medium green peas of finest quality. 2 lbs., $60 \mathrm{c} ; 7$ lbs., \$I.40; I 4 lbs., \$2.50; 56 lbs., \$9.50.

BLUE BANTAM-This dwarf, wrinkled Pea combines extreme earliness, superb quality, and unusual productiveness, growing a very large pod for such a dwarf Pea. Vines average 15 inches in height, are very vigorous and carry enormous crops of large, deep bluish green pods. The pointed pods are 4 to $4 \frac{1 / 2}{2}$ inches long, smooth, and packed tightly with 8 to Io extra-large luscious Peas. 2 lbs., 6oc; 7 lbs., \$1.65; I4 lbs., \$2.90; 56 lbs., \$10.75.

\section{PUMPKIN}

Oz. $1 / 4$ lb. Lb. 5 lbs. Common Yellow Field .. \$o.Io \$o.20 \$o.6o \$2.75 Large Sweet or Ky. Field .Io $\begin{array}{lll}.15 & .50 & 2.00\end{array}$ Large Sweet Cheese .... . . . I0 Mammoth Potiron ....... .I5 .40 I.I5 $\begin{array}{lllllll}\text { Small Sixeet or Sugar .. } & .10 & .25 & .75 & 3.65\end{array}$ Winter Luxury .......... . . $5 \quad .40 \quad$ I.25

Postpaid.

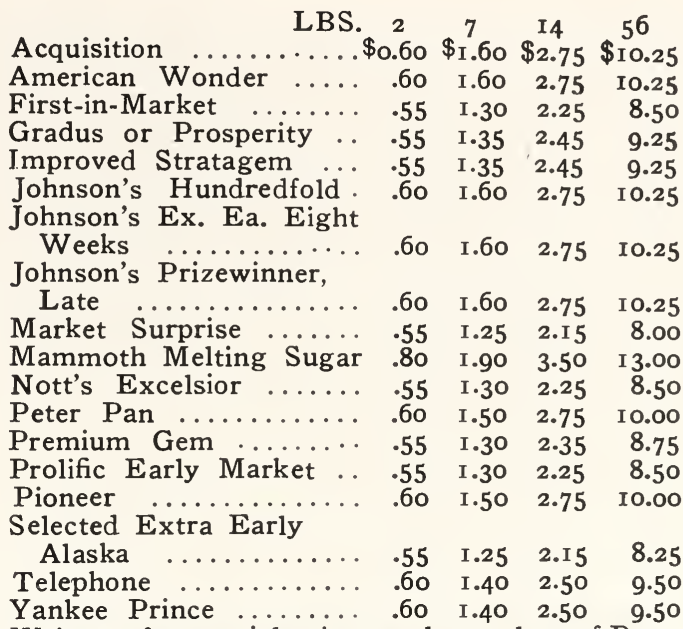

Write us for special prices on larger lots of Peas.

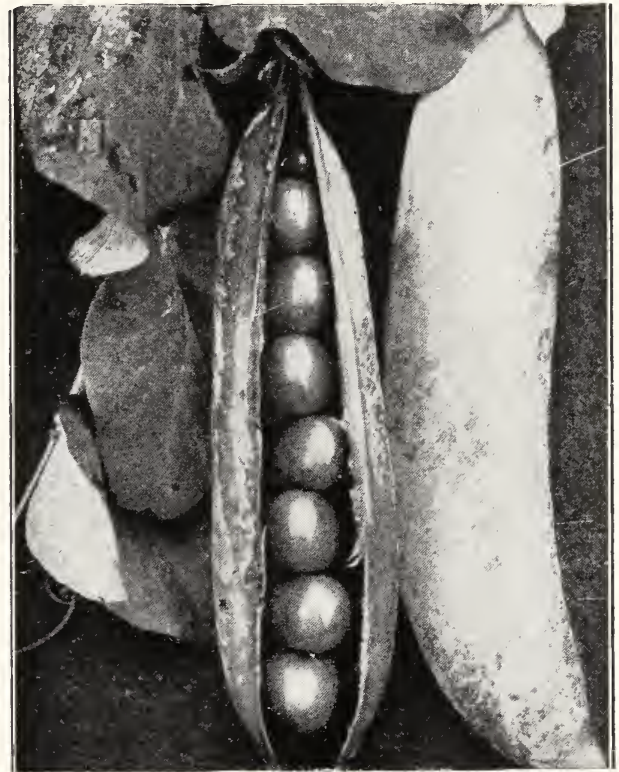

Little Marvel

\section{PARSLEY}

CHAMPION MOSS CURLED-Our stock is a vigorous compact growing strain, excellent for garnishing and flavoring. Owing to its uniformly fine deep green color and very attractive foliage, our stock is very ropular for the market and garden. Oz., I0c; $1 / 4$ lb., 25c; lb., 75c; 5 lbs., \$3.25; Io lbs., \$6.0o. Postpaid.

HAMBURG or TURNIP-ROOTED-The root resembles a small parsnip, both in color and shape. The roots can be dug late in the fall and stored in sand for winter sales. They are extensively used for flavoring soups and stews. Oz., I0c; 1/4 lb., 30c; lb., 90c; 5 lbs., \$4.00; Io lbs., \$7.00. Postpaid.

Fine Double Curled ....\$o.ro \$o.25 \$o.85 \$4.00 Johnson's Bouquet ....... Plain ................ 


\section{JOHNSON'S PEPPERS}

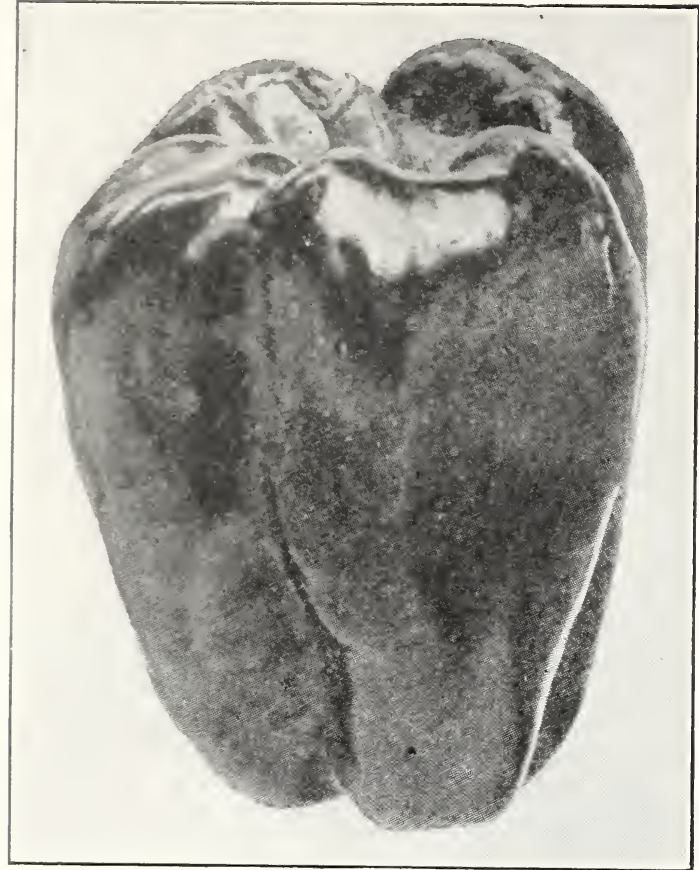

Johnson's World Beater

WORLD BEATER-This is a cross between Chinese Giant and Ruby King, having the shape of the Ruby King, except that it is broader at the pointed end. It is far more prolific than Chinese Giant. Color beautiful shade of scarlet. $1 / 2$ oz., 20c; oz., 35c; 1/4 lb., \$I.IO; lb., \$3.50. Postpaid.
CALIFORNIA WONDER-(New) A very striking new sort of large size and having wonderfully thick flesh-often $1 / 4$ to $3 / 8$ inch thickwhich is deliciously crisp, tender and sweet, like the finest pimentoes. In color it is a brilliant dark green, changing to crimson when ripe, and is of uniform shape and smoothness. $1 / 2$ oz., 35c; oz., 6oc; $1 / 4$ lb., \$I.90; lb., \$6.50. NEW RUBY GIANT-The result of a cross between Ruby King and Chinese Giant, combining the vigor and size of Chinese Giant with the earliness and hardiness of Ruby King. Brilliant scarlet; flesh thick and sweet. $1 / 2$ oz., 25c; oz., 45c; 1/4 lb., \$I.35; lb., \$4.00. Postpaid.

JOHNSON'S MAMMOTH LONG RED-A long type that has sufficient pungency to make it delicious, but is not extremely hot. The fruits are very meaty, measuring 7 inches or more in length, with a diameter of $I$ inch. It is surprisingly productive. $1 / 2$ oz., 20c; oz., 30c; 1/4 lb., \$I.00; lb., \$3.50. Postpaid.

$1 / 2 \mathrm{oz}$. Oz. 1/4 lb. Lb. Chiant ........\$0.25 \$0.45 I.40 \$5.00 Large Bell or Bull Nose . . . $5 \quad .35 \quad .95 \quad 3.50$ Extra Early Red Prolific.. .20 .30 I.00 3.50 Ohio Crimson .............. .25 .40 $1.30 \quad 4.50$ Prolific Yellow ......... .20 .30 $1.00 \quad 3.50$ Long Red Cayenne .........20 $.20 \quad .35$ I.00 3.75 $\begin{array}{lllll}\text { Neapolitan Early (large).. } & .20 & .30 & .85 & 3.00\end{array}$ Oshkosh (new) ............ 35 .6o $2.00 \quad 6.50$ Royal King .............. . .5 $\quad .25 \quad .80 \quad 2.75$ Ruby King ........... $2.20 \quad 35$ I.00 3.50

Small Cayenne or Red

Chili .................20 $\quad .20 \quad .90 \quad 3.25$ Sunnybrook $\ldots \ldots \ldots \ldots \ldots . .25 \quad .40 \quad 1.25 \quad 4.00$ $\begin{array}{lllll}\text { Sweet Salad or Perfection } & .20 & .30 & .85 & 3.00\end{array}$ $\begin{array}{llllll}\text { Tomato-shaped } \ldots \ldots \ldots \ldots & .20 & .30 & .90 & \mathbf{3 . 2 5}\end{array}$ All Peppers are postpaid.

\section{KOHLRAB|}

Oz. 1/4 lb. Lb. Early White Vienna .......\$o.I5 \$o.35 \$I.25 Earıy Purple Vienna ....... .20 .65 2.00 Early White Short-leaved .. $.15 \quad .50 \quad$ I.75

\section{MUSHROOM SPAWN}

AMERICAN PURE-CULTURE SPAWNBrick, 25C; 50 bricks, \$I2.00; I00 bricks, \$23.00. Not prepaid.

\section{OKRA}

Oz. $1 / 4 \mathrm{lb}$. Lb. $5 \mathrm{lbs}$.

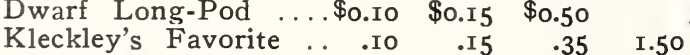
Perkins' Mammoth ... .Io .Io .I5 $\quad .35$ I.50 White Velvet ........ .I0 .I5 .35 I.

\section{Rhubarb or Pie Plant}

Our seed is saved from selected plants of the Linnaeus, Victoria, Giant and other improved sorts, but like the seeds of fruit trees, rhubarb seed cannot be relied upon to reproduce the same varieties. Oz., Ioc; 1/4 lb., 30c; lb., \$I.00; 5 lbs., \$4.75. Postpaid.

\section{Salsify or Vegetable Oyster}

MAMMOTH SANDWICH ISLAND-Roots much larger and more uniform than the older type; pure white. Oz., I5c; $1 / 4$ lb., 50c; lb., \$I.75. Postpaid.
My 3 acres of your selected Davis Perfect Cucumbers brought more money than I have made on this crop in some years. They were sure a fine color and very uniform in shape.-C. M. Herrin, Erie Co., Pa.

Last year my neighbor advised me to try some of your stock seed of Beauty Tomato. I must say that I was unusually pleased.\{D. E. Brodbeck, Lucas County, Ohio.

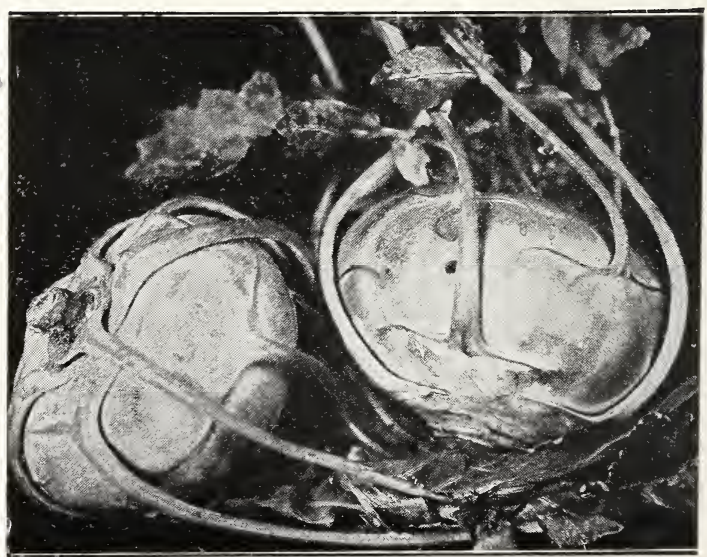

Kohlrabi 


\section{RADISH}

JOHNSON'S EXTRA SELECT SCARLET GLOBE-(See cut). We have an exceptionally fine stock of this superb variety. It is one of the very earliest of the forcing radishes and does equally well outside; roots are globe shape and with a very small top; always crisp and tender. Color a bright scarlet. Oz., Ioc; $1 / 4 \mathrm{lb}$., $25 \mathrm{c}$; lb., 8oc; 5 lbs., $\$ 3.90$; Io lbs., $\$ 7.50$; 25 lbs., \$17.50. Prepaid.

Reselected Stock-Oz., IOc; 1/4 lb., 30c; lb., 9oc; 5 lbs., \$4.0o. Postpaid.

Greenhouse Stock-Oz., I5c; 1/4 1b., $35^{c}$; lb., \$I.oo; 5 lbs., \$4.50. Postpaid.

NEW SAXA-The earliest of the forcing radishes, and one of the slowest to shoot to seed. Round, bright scarlet and with the smallest possible top. We have an excellent stock of this radish and can highly recommend it. Oz., Ioc; 1/4 lb., 30c; lb., \$1.00; 5 lbs., \$4.65. Postpaid.

\section{SPARKLER WHITE TIP-Quite simi-} lar to Scarlet Turnip White Tipped as to size and time of maturity. The root, however, is more round or ball shaped, and the white extends further up on the radish, and on this account is more popular in many markets. Oz., IOc; $1 / 4$ lb., 25c; lb., 75 c; 5 lbs., $\$ 3.50$. Postpaid. NON PLUS ULTRA or FIREBALL-Round rather than turnip-shaped, of medium size with a moderate top; bright scarlet; very early, and one of the best forcing varieties, following Saxa in three or four days. Oz., Ioc; $1 / 4 \mathrm{lb}$., $25 \mathrm{c}$; lb., $85 \mathrm{c} ; 5$ lbs., $\$ 4.00$. Postpaid.

LIVINGSTON'S PEARL-A splendid long,

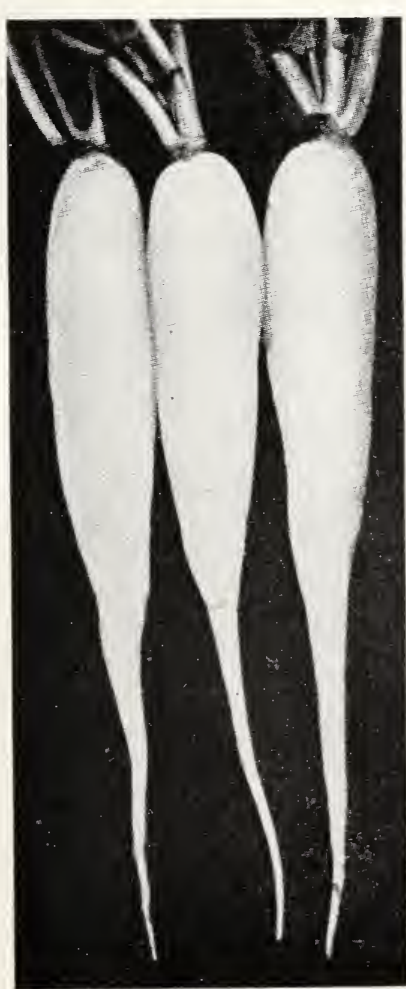

Johnson's Icicle pearly white vari e ty of rapid growth; the roots remain fit for use a full two weeks before going to seed; quite similar to Icicle. Oz., roc; $1 / 4$ 1b., 25c; lb., 8oc; 5 lbs., \$3.75. Postpaid.

J O H N S N'S L O N G WHITE ICICLE - (S e e cut). The leading long white radish and one of the earliest; somewhat shorter, broader at the top and more square shouldered than Lady Finger, also matures a little earlier; about 6 inches long and white throughout. Oz., IOc; $1 / 4$ lb. 25c; lb., 8oc; 5 lbs., \$3.75. Postpaid.

CIN C I N N A T I MARKET - Best long red variety, tops so srhall that the Radishes may

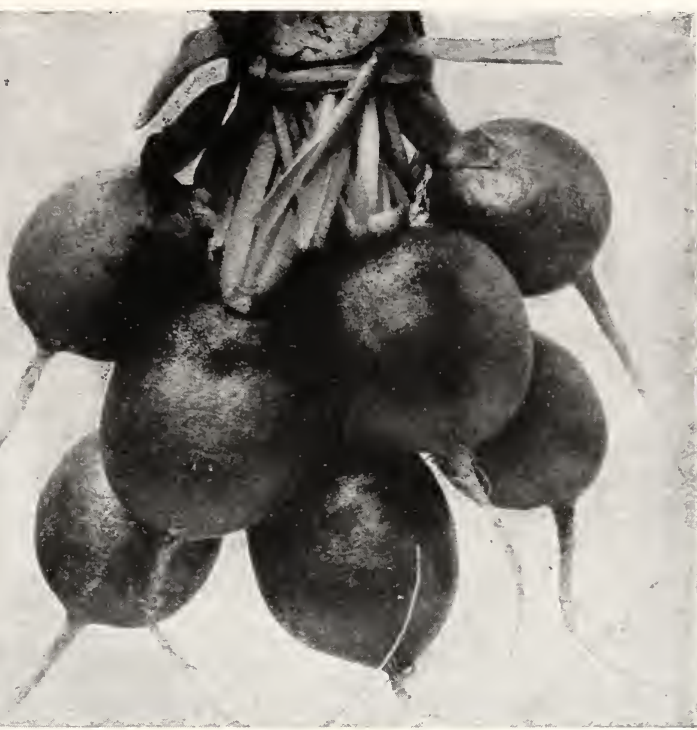

Johnson's Extra Select Scarlet Globe

stand almost touching each other in the rows. It grows perfectly straight and smooth, 6 to 7 inches in length. Skin scarlet, very thin, flesh crisp, brittle and of delightful flavor. The finest long red Radish in existence. Oz., Ioc; $1 / 4$ lb., 25c; lb., 65c; 5 lbs., \$300; 10 lbs.. \$5.50; 100 lbs., \$48.0o. Postpaid.

\section{Four Best Winter Radishes}

WHITE CHINESE (New Celestial) - A large stump-rooted winter radish with white skin and flesh. Can be sown from July I to August I5, and will keep in prime condition a long time; mild in flavor; brittle and never woody. Oz., Ioc; 1/4 lb., 25c; lb., 8oc; 5 lbs., \$3.75. Postpaid. CHINESE ROSE WINTER-A very handsome and distinct bright rose variety, crisp and tender; cylindrical in shape, very smooth. Very desirable sort. Keeps splendidly through autumn and winter. Oz., Ioc; 1/4 lb., 25c; 1b., 8oc; 5 lbs., \$3.75. Postpaid.

LONG BLACK SPANISH WINTER-Grows 5 to 8 inches long and is $I$ to $I \frac{1}{4}$ ins. through at top. Skin black; flesh white and firm. Oz.. Ioc; 1/4 lb., 25c; lb., 8oc; 5 lbs., \$3.75. Postpaid.

ROUND BLACK SPANISH WINTERSimilar to Long Black Spanish, except in shape. Fine for winter. Oz., Ioc; 1/4 lb., 25c; lb., 8oc; 5 lbs., \$3.75. Postpaid.

Oz. $1 / 4$ lb. Lb.

Early Long Scarlet Short-Top.\$o.io \$o.25 \$o.75

Early Scarlet Turnip ........ . . Io $.25 \quad .75$

Early Snowball ....5 lbs., $\$ 3.50$. I0 $\quad .25 \quad .75$

French Breakfast ..5 lbs., \$3.00 .10 $.20 \quad .65$

Golden Globe ............... . I0 .30 1.00

Half-Long Deep Scarlet ...... . . . $\quad .25 \quad .75$

Improved Chartier. .5 lbs., $\$ 3.50$.I $\quad .25 \quad .75$

Large White Summer Turnip... Io. $\quad .25 \quad .75$

Model White Box ........... .10 .25 $\quad .75$

Rosy Gem (Forcing White-

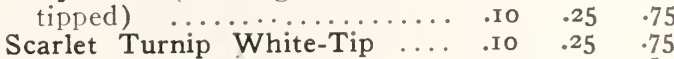

White Delicious ............... .10 $.25 \quad .80$

White Giant Stuttgart ....... . . $\quad .30$ I0 1.00 


\section{SPINAGH}

One ounce will sow Ioo feet of row; I5 pounds will sow an acre in rows, 25 pounds if broadcast.

KING OF DENMARK-The leaves are large, smooth or somewhat crumpled and very dark green. Long petiols. The plants remain a long time in marketable condition without going to seed. One of the best varieties for Spring Sowing. Oz., 5c; 1/4 lb., Ioc; lb., 32c; 5 lbs., \$1.25; Io lbs., \$2.25. Postpaid.

JOHNSON'S JULIANA-Very dark green crumpled leaves, rounded and thick. It lacks entirely the earlier bolting male plants, so that the crop as a whole remains much longer in prime condition. It is therefore one of the best long standing varieties. Oz., 5c; 1/4 lb., Ioc; lb., 32c; 5 lbs., \$I.25; Io lbs., \$2.35. Postpaid.

NEW LONG-STANDING SAVOY-LEAVED-A fine strain of outstanding merit. It will stand in marketable condition Io to I4 days longer before bolting than regular Savoy and is darker green. It is intensely crumpled and blistered and very uniform. Wherever Bloomsdale is grown, this improved strain gives satisfactory results. Oz., 5c; 1/4 lb., IOc; lb., 32c; 5 lbs., \$1.30; Io lbs., \$2.35. Postpaid.

BLOOMSDALE SAVOY-LEAVED, Reselected-Best for fall, but if sown very early in the spring will produce a good crop. This early, productive variety produces large, glossy dark green leaves, crumpled or blistered, very thick and great substance. The most largely grown Spinach. Has tendency to bolt to seed in warm weather. Oz., 5c; 1/4 lb., Ioc; lb., 33c; 5 lbs., \$I.55; Io lbs., \$2.80. Postpaid.

\section{SQUASH Winter Varieties}

One ounce will plant about I5 hills; 4 pounds will plant an acre.

IMPROVED HUBBARD-The standard winter squash; fruits large, heavy and moderately warted; shell dark bronze green, showing more or less light green markings toward blossom end; flesh bright orange yellow, fine grained, thick and dry. Oz., I5c; 1/4 lb., 35c; lb., \$I.IO; 5 lbs., \$5.00, Postpaid.

CHICAGO WARTED HUBBARD-Similar

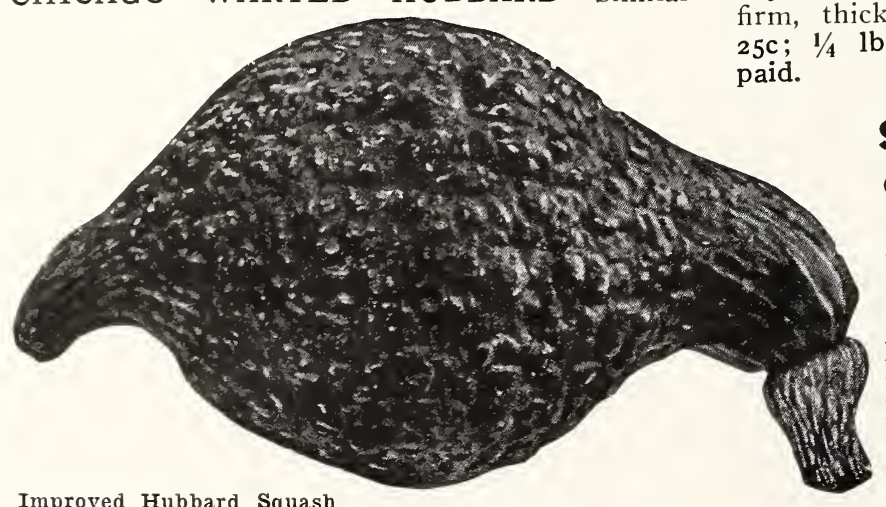

Improved Hubbard Squash

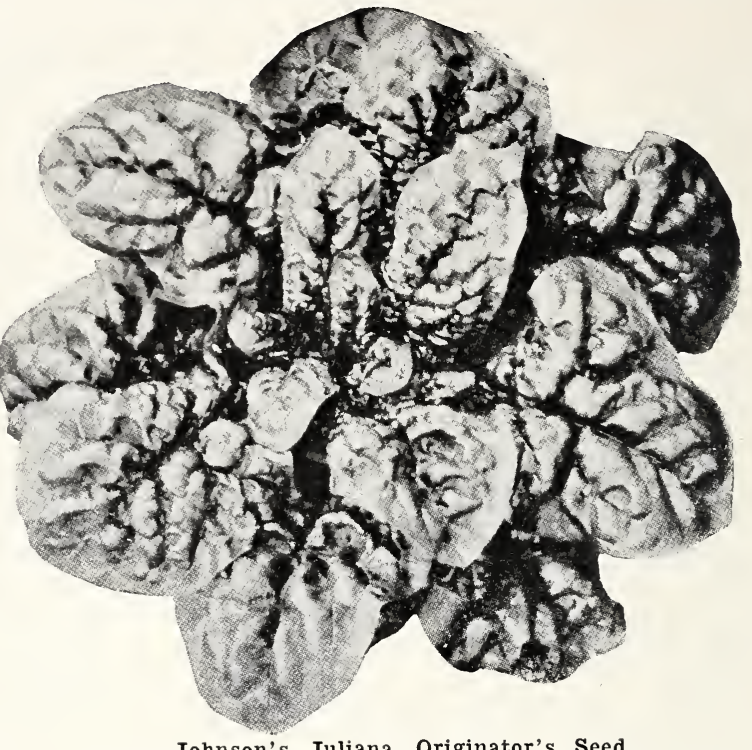

Johnson's Juliana Originator's Seed

EVERLASTING, or NEW ZEALAND-Distinct; endures heat; best for summer. Thrives during the hot weather in any soil, rich or poor. Shoots of good quality and may be cut throughout the summer. Oz., Ioc; 1/4 lb., I5c; lb., $50 c$. Improved Thick-Leaf Oz. 1/4 lb. Lb. 5 lbs. Viroflay .........\$0.05 \$0.10 \$0.28 \$I.25

Long Season ......... .05 .10 .25 I.I5

Nobel or Big Crop (New) .05 .Io $\quad .33$ I.55

$\begin{array}{lllll}\text { Prickly-Seeded Winter.. } & .05 & \text {.I0 } & .28 & \text { I.25 }\end{array}$

Virginia Blight-Resistant

Savoy .............. .05 .IO .30 I.I5 Victoria $\ldots \ldots \ldots \ldots \ldots \ldots \ldots$.05 10 . 10 .30 1.40

Above prices are postpaid. Ask for prices on larger lots of Spinach.

in size and quality to the well known Hubbard, but is more heavily warted and a very dark green, almost black, in color. Our stock of this variety is exceptionally true. Oz., I5C; 1/4 lb., 40c; lb., \$1.25; 5 lbs., \$5.25. Postpaid.

RED or GOLDEN HUBBARD-The shell is moderately warted, hard, strong and of a rich orange red color. Flesh deep orange, dry and of best quality; an excellent keeper. Oz., I5c; $1 / 4$ lb., 40c; lb., \$1.20; 5 lbs., \$5.00. Postpaid.

BLUE HUBBARD-A type of the well-known Warted Hubbard but excelling it in flavor and dryness. The attractive light blue skin and frm, thick flesh make it very popular. Oz. 25c; 1/4 lb., 70c; lb., \$2.20; 5 lbs., \$9.75. Post-

\section{Summer Varieties}

One ounce will plant about 25 hills; 3 pounds will plant an acre.

MAMMOTH SUMMER CROOKNECK-A fine early variety of the Crookneck type, with vines of bush habit, large and vigorous. The fruits, when mature, are often $I_{1 / 2}$ to 2 feet long, curved at the neck, with a densely warted, golden yellow surface. Oz., I5c; $1 / 4$ lb., 35c; lb., \$I.20; 5 lbs., $\$ 5.50$. Postpaid. 
(SQUASH, Summer Varieties-Con't.) "DES MOINES"-This is a small acorn-shaped dark green Squash, almost black, about 5 or 6 inches long and + inches in diameter. Oz., 2oc; 1/4 lb., 50c; lb., \$1.75; 5 lbs., \$7.25. Postpaid.

MAMMOTH YELLOW BUSH or GOLDEN CUSTARD-This is identical to the Mammoth White Bush, but the fruits are even larger and have a rich, golden orange skin as well as rich creamy yellow flesh. Oz., I5c; 1/4 lb., 30c; lb., \$1.00. Postpaid.

MAMMOTH WHITE BUSH - True bush growth, and produces large fruits with scalloped edges, frequently 12 to $\mathrm{I} 4$ inches in diameter. Oz., I5c; 1/4 lb., 35c; lb., \$I.Io. Postpaid.
GIANT ITALIAN SUMMER-This is about the size and shape of a baseball bat. Very popular where there is a large foreign population. Color white. Must be used before becoming hard. Oz., 25c; 1/4 lb., 6oc; lb., \$1.70. Postpaid.

DELICATA-An early ripening winter sort producing an enormous crop of oblong fruits. Orange yellow, striped with green. Known as "Sweet Potato" Squash. Oz., 20c; 1/4 lb., 55c; lb., \$I.go. Postpaid.

Boston Marrow .........\$0.15 \$0.25 \$o.8o

Cocozelle .................. .15 .40 1.25

Fordhook ............... . I5 .35 1.20

Gregory's Delicious ........... . I5 .35 I.I5

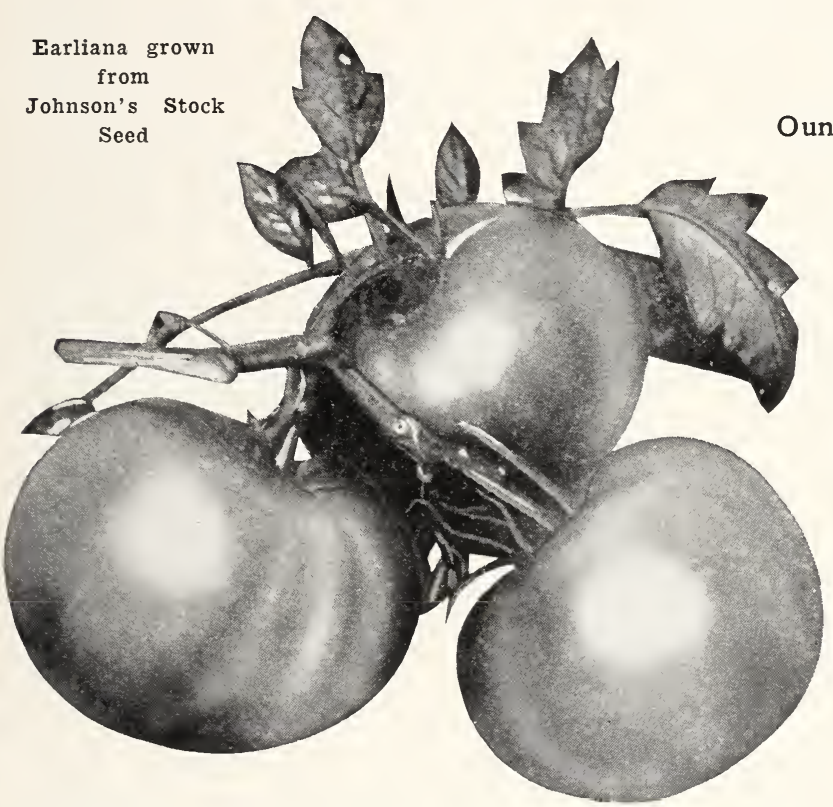

\section{TOMATOES}

Ounce produces $\mathrm{I}, 000$ to 2,000 plants.

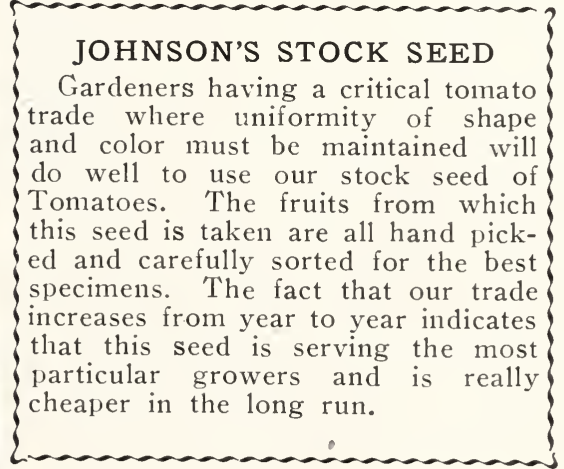

All Tomato Seed is Postpaid.

SELECT EARLIANA-The earliest and best of the very early Tomatoes; fruit smooth, solid and produced in clusters; color bright scarlet. Our many years of selection on this stock has made it unequalled. $1 / 2$ oz., 20c; oz., 35c; $1 / 4$ lb., \$1.00; lb., \$3.50. Postpaid.

JOHNSON'S STOCK SEED EARLIANAOz., \$I.00; 2 oz., \$I.75; 1/4 lb., \$3.00.

EARLY DETROIT - A very fine, early, largefruited purple variety; fruits globe-shaped, smooth and solid. 1/2 oz., 20c; oz., 30c; 1/4 lb., $\$$ I.00; 1b., \$3.50.

GLOBE (Livingston's) - A very vigorous, productive, medium early tomato, much in favor for greenhouse forcing; fruit globe-shaped, smooth and solid; color purplish pink. 1/2 oz., 20c; oz., 30c; 1/4 lb., \$1.0o; lb., \$3.50.

JOHNSON'S STOCK SEED GLOBE-Per oz., \$1.00; 2 ozs., \$1.75; 1/4 lb., \$3.00.

BONNY BEST-Very smooth, solid, uniform, and produced in clusters; ripens uniformly and is very productive; color bright red. $1 / 2 \quad$ oz., 20c; oz., 30c; $1 / 4$ lb., \$1.0o; lb., \$3.50.

JOHNSON'S STOCK SEED BONNY BEST -Per oz., \$I.00; 2 ozS., \$I.75; 1/4 lb., \$3.00.
CHALK'S EARLY JEWEL-Fruit uniformly smooth, round and solid; color crimson. $1 / 2$ oz., 20c; oz., 30c; 1/4 lb., \$1.00; lb., \$3.50.

MATCHLESS-A large smooth, second early sort; color red. $1 / 2$ oz., 20c; oz., 30c; 1/4 lb., \$1.00; lb., \$3.50.

PONDEROSA-An exceptionally large, purple-fruited tomato. We have much improved this stock. $1 / 2$ oz., 20c; oz., 35c; 1/4 lb., \$1.25; lb., $\$ 4.75$.

GOLDEN QUEEN-The fruits are large and smooth, of bright golden yellow color. $1 / 2 \mathrm{oz}$, 20c; oz., 35c; 1/4 lb., \$1.10; lb., \$4.00.

STONE_-The standard and general favorite with truckers and canners; always dependable, very vigorous and productive; fruits round, large, solid, smooth and deep red in color. Our selected stock of Stone is much above the average. $1 / 2$ oz., 20c; oz., 35c; 1/4 lb., \$I.00; lb., $\$ 3.50$.

TRUCKERS' FAVORITE-A popular purplefruited sort on the order of Beauty and of the same general habit of growth; the fruit is, however, more flattish. $1 / 2$ oz., 20c; oz., 3oc; $1 / 4$ lb., 9oc; lb., \$3.50. 


\section{(TOMATOES-Continued)}

BEAUTY - A productive main crop variety; fruits large and exceptionally smooth, solid and of excellent quality; color purplish pink. $1 / 2 \quad$ oz., 25c; OZ., 40c; 1/4 lb., \$I.30; lb., \$4.25.

JOHNSON'S STOCK SEED BEAUTY-Per OZ., \$I.00; 2 oZS., \$I.75; 1/4 lb., \$3.00.

DWARF CHAMPION-Of a distinctly dwarf, compact, upright growth; fruits smooth, solid and medium size. Color pink; quite early. 1/2 oz., 25c; oz., 40c; 1/4 lb., \$I.30; lb., \$4.25.

EARLY ACME-Hardy, early and productive; color purplish pink. $1 / 2$ oz., 25c; oz., 40c; $1 / 4$ lb., \$I.20; lb., \$3.70.

JOHN BAER-We have a splendid uniform stock of this variety. $1 / 2$ oz., $25 \mathrm{c} ;$ oz., $40 \mathrm{c} ; 1 / 4$ lb., \$I.0o; lb., \$3.25.

DWARF STONE-The largest fruited of the upright varieties. Vines are vigorous, and bear large, smooth, bright red, solid fruits. $1 / 2$ oz., 25c; oz., 40c; 1/4 lb., \$1.20; lb., \$3.8o.

MARGLOBE-New midseason sort. A hybrid from Marvel and Livingston's Globe. Entirely immune from rust and wilt. A pure scarlet, globe-shaped, with the size and fine qualities of Livingston's Globe but earlier and a heavier cropper. Valuable for canning and marketing due to its solidity, scarlet color and fine appearance. $1 / 2$ oz., 30c; oz., 50c; $1 / 4$ lb., lb., \$1.30; lb., \$4.50.

\section{TURNIP}

P U R P E TOP W H T E GLOBE - Almost a perfect globe in form; flesh and skin white, colored purple or red above ground; very fine grained and sweet; a superior variety. Oz., Iоc; 1/4 lb., 20c; lb., 55c; 5 lbs., \$2.50. Postpaid.

EXTRA EARLY PURPLE TOP MILAN-Extremely early and of splendid quality; bulbs of medium size, flat and white, with a bright purple top. Oz. I5c; $1 / 4$ lb., 30c; lb., \$I.00. Postpaid.

PURPLE TOP STRAP LEAVED-A widely cultivated variety; a-very early, productive sort; roots are flat, medium-sized, purple or dark red above ground, white below; flesh white, tender and fine grained. Oz., Ioc; $1 / 4$ lb., 2oc; lb., 5oc; 5 lbs., $\$ 2.25$, postpaid.

Oz. $1 / 4$ lb. Lb. 5 lbs.

\section{Early Snowball}

Extra-Early White Milan .I0 $.25 \quad .65 \quad 3.00$

Early White Flat Dutch. $.10 \quad .20 \quad .45 \quad 2.00$

Early White Egg ......

Golden Ball or Orange

Jelly ............... . 10 $20 \quad$.6o $\quad 2.25$

Large White Globe .....

Long White or Cowhorn .I0 $\quad .20 \quad .50 \quad 2.00$

Seven Top ... I0 lbs., \$3.25 $\quad$.10 $\quad .20 \quad .50 \quad 2.00$

Yellow or Amber Globe $\begin{array}{llll}\text {.IO } & .20 & .50 & 2.50\end{array}$

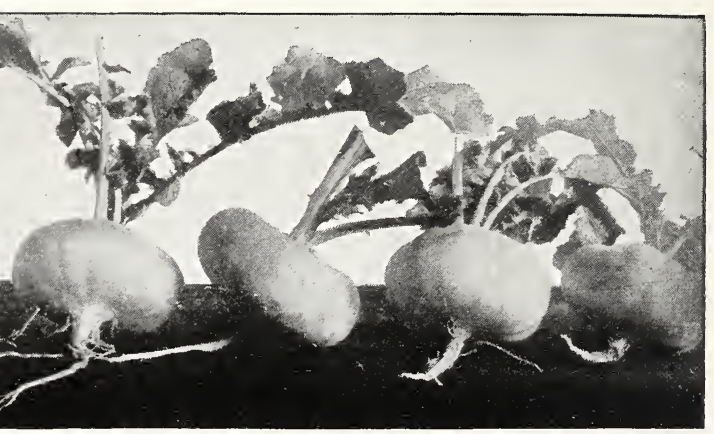

Extra Early Purple Top Milan

\section{RUTABAGA}

IMPROVED AMERICAN PURPLE TOPA hardy, productive variety with a small neck; roots are large, oblong or globular in form, with a very small tap root; color bright yellow with a purple top; flesh very solid, tender and sweet. Oz., I5c; $1 / 4$ lb., 25c; lb., $65_{5}$; 5 lbs., \$2.50. Postpaid.

WHITE PERFECTION-Skin and flesh are white. It forms large, smooth, solid, slightly elongated roots of choice quality both for table use and for cattle feeding. A splendid winter keeper. Oz., I5c; 1/4 lb., 25c; lb., 8oc. Postpaid.

We Have Been Specialists in Market Growers Stocks for 35 Years.

\section{EARLIER, MORE PROFITABLE CROPS}

Germaco HOTKAPS can make many extra dollars for you this season. They are patented wax paper cones-"individual hothouses

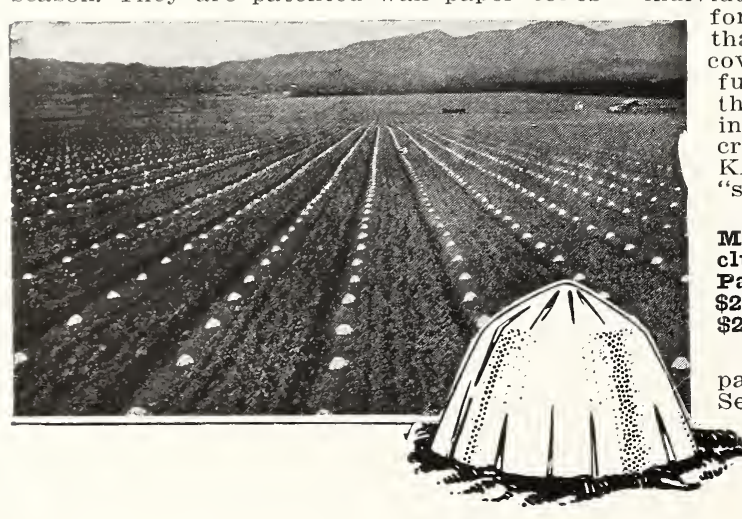
for each plant" that completely fully protect wind rain, ground crusting and them from frost, wind, rain, ground crusting and insects. This is your assurance of earlier, bigger crops, and higher early-to-market pres. One man "sets" over 3,000 per day.

Prices: 1,000 lots, $\$ 11.50 ; 5,000$ lots, $\$ 11.00$ per T; 10,000 lots, \$10.75 per M; 250 Trial Package, including Garden Setter with Tamper, $\$ 4.00$; 100 Home Package, including Garden Setter with Tamper, \$2.50; Germaco Hotkap Steel Setter with Tamper,

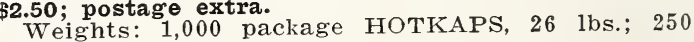
package, 9 lbs., 100 package, 5 lbs.; Steel Hotkap Setter. 3 lbs. 


\section{Johnson's Reliable Flower Seeds}

For Market Gardeners and Florists

Many market gardeners and truckers add considerably to their income by growing a quantity of the popular Summer cut flowers and pot plants, such as Asters, Cosmos, Petunias, Salvias, Sweet Peas, etc.

\section{ASTERS}

Our Aster Seed is raised by experienced and reliable Seed Growers and should not be compared with stock raised by experimenters who use no care and lack experience.

CREGO-Comes into bloom just ahead of the Late Branching. Purple, White, Pink, Lavender. $1 / 8$ oz., 25c; 1/4 oz., 45c; oz., \$r.50.

GIANTS OF CALIFORNIA-We offer this remarkable New Aster in White, Light Blue, Deep Rose, Dark Purple, Mixed. 1/8 oz., 50c: $1 / 4$ oz., 90c; oz., \$3.00.

HEART OF FRANCE-The best pure red Aster. In any light natural or artificial, Heart of France is startlingly beautiful and will command instant admiration. $1 / 8$ oz., $40 \mathrm{C} ; 1 / 4$ oz., $75 \mathrm{c}$; oz., $\$ 2.35$.

SEMPLE'S GIANT BRANCHING-Stands at the head of the list as a florist's flower. Mixed, Lavender, Purple, White, Crimson and Shell-Pink. 1/8 oz., 25c; 1/4 oz., 45c; oz., \$I.50. ROCHESTER-The Rochester Asters are of the Crego type, but are larger and with longer stems. Mixed, White, Purple, Shell-Pink and Lavender. $1 / 8$ oz., 35c; $1 / 4$ oz., 65 c; oz., \$2.0o.

KING-In form the flower is entirely distinct from any other variety. Has long, narrow quilled petals. White, Pink, Violet, Rose, Mixed. $1 / 8$ oz., 30c; $1 / 4$ oz., 50c; oz., \$1.75.

QUEEN OF THE MARKET-About two or three weeks earlier than most Asters. Mixed,

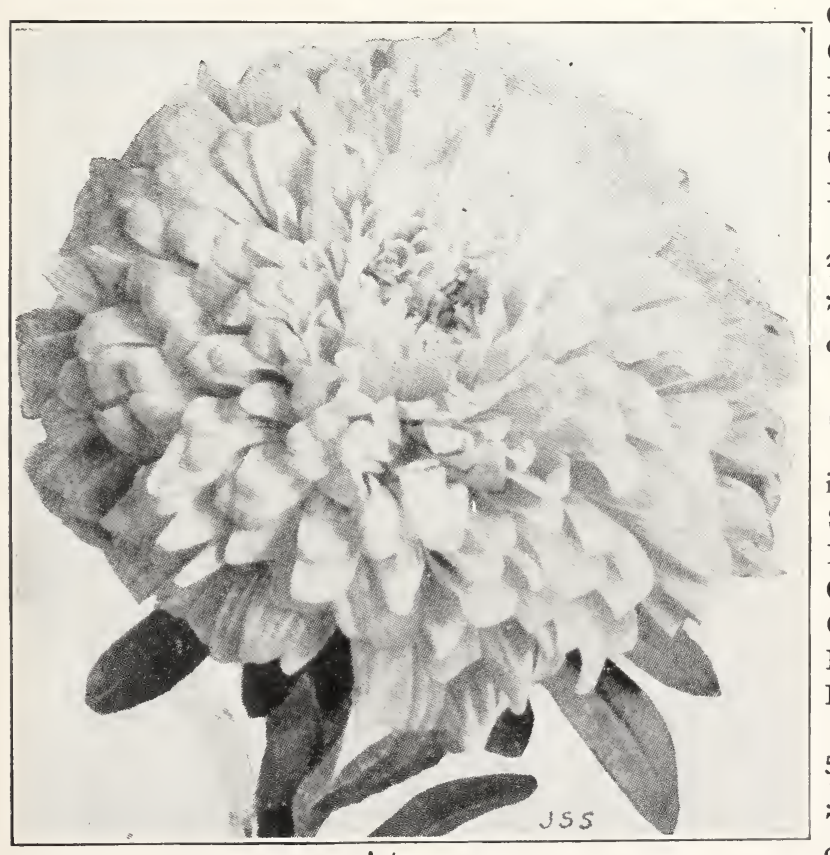

Asters
Scarlet, Pink, Crimson, White, Dark Blue and Light Blue. 1/8 oz., 25c; 1/4 oz., 40c; oz., \$1.25. SENSATION-This is the darkest red of all Asters. 1/8 oz., 35c; 1/4 oz., 65c; oz., \$2.00.

JOHNSON'S IDEAL MIXTURE-This mixture includes the cream of not only this list but also every sort from our complete collection. Our best mixture in Asters. Height averages about 2 feet. $1 / 8$ oz., 30c; $1 / 4$ oz., 50c; OZ., \$1.75.

\section{AGERATUM}

H. H. A. Floss Flower. Flowers forming in heads and blooming continuously all summer. Valuable for borders and edgings.

FINEST MIXED- $1 / 4$ oz., 20c; oz., $50 c$.

BLUE PERFECTION-Dark blue. 1/4 oz., 25c; oz., $65 \mathrm{c}$.

LITTLE BLUE STAR-Fine for bedding. I/I6 oz., 4OC; 1/8 oz., 65c.

LITTLE DORRIT-Azure blue. 1/8 oz., $30 \mathrm{c}$.

\section{ALYSSUM H. A.}

Useful for beds, edgings, or rockeries. Thrives anywhere and blooms all summer.

CARPET OF SNOW-The best variety for beds or borders. Pure white. 3 to 4 in. $1 / 4$ oz., I5c; Oz., 50c.

SWEET-Excellent for cutting. Pure white. 6 to 8 in. $1 / 4$ oz., Ioc; oz., $25 \mathrm{c}$.

BENTHAMII (Compactum) - Very distinct sort, with upright spikes. H. A. 6 in.

BENTHAMII, Yellow-1/4 oz., 20c; oz., $50 c$. BENTHAMII, Lilac-1/4 oz., 20c; oz., $50 \mathrm{c}$. SAXATILE COMPACTUM-Hardy yellow. H.P. 12 in. 1/4 oz., 20c; oz., 6oc.

\section{ANTIRRHINUM Large-Flowering Giant}

Crimson King-Rich garnet crimson. Golden King-Rich yellow.

Fire King-Brilliant orange scarlet. Harmony-Terra cotta shaded rose. Queen Victoria-Purest white.

Rose King-Soft silvery rose.

Any of the above varieties: Trade pkt., $25 \mathrm{c}$; $1 / 8$ oz., $45 \mathrm{c} ; 1 / 4$ oz., $75 \mathrm{c}$; oz., \$2.50. Johnson's Finest Mixed-All colors. Trade pkt., 20c; 1/8 oz., 40c; $1 / 4$ oz., $65 \mathrm{c}$; oz., $\$ 2.30$.

\section{Large-Flowering Half-Dwarf}

A splendid type, growing about is ins. high; best for bedding purposes.

Silver Pink-Soft pearly pink.

Empress-Rich velvety crimson.

Golden Queen-Rich yellow.

Grenadier-Fiery orange scarlet.

Purity-Snowy white.

Fawn-Rose and gold.

Any of above, Trade pkt. $30 c ; 1 / 8 \mathrm{oz}$. 5oc; $1 / 4$ oz., 85 c; oz., \$2.75.

Johnson's Finest Mixed-All colors. Trade pkt., 20c; $1 / 8$ oz., 40c; $1 / 4$ oz., 65 c; oz., $\$ 2.30$. 


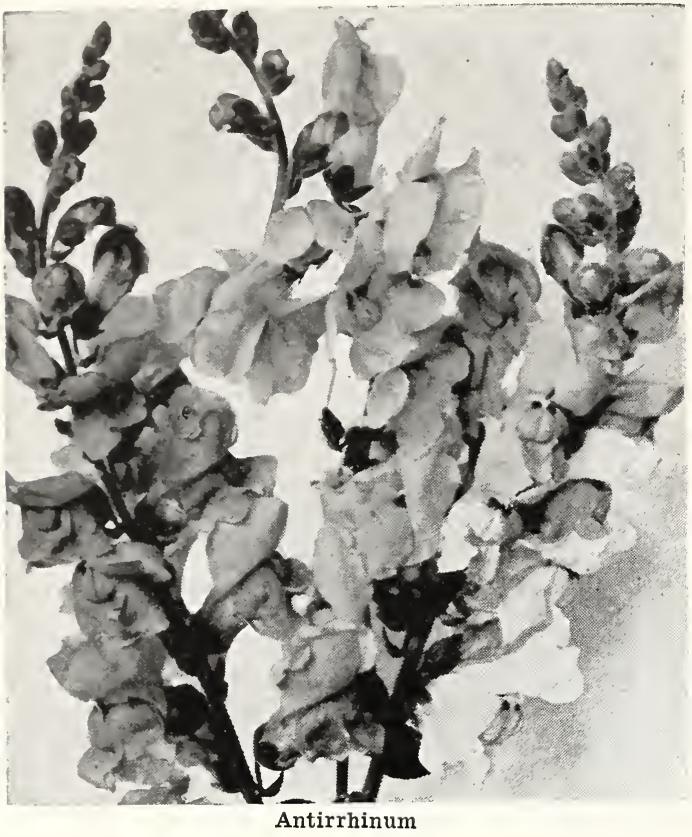

(ANTIRRHINUM-Continued)

\section{Maximum or Super-giant}

A new strain of tall growth producing long spikes of gigantic flowers.

Appleblossom-Soft appleblossom pink.

Canary Bird-Canary yellow with deeper yellow lip.

Copper King-Bronzy copper color.

Old Gold-Rose on yellow ground.

Snowflake-Dazzling white.

The Rose-Rich rose pink.

Any of the above, Trade pkt., 35c; $1 / 8$ oz., 50c; $1 / 4$ oz., 85c; oz., \$2.75.

Super-giant Mixed-All colors. Trade pkt. 25c; 1/8 oz., 45c; 1/4 oz., 75c; oz., \$2.50.

\section{AQUILEGIA (Columbine)}

LONG-SPURRED HYBRIDS-A beautiful strain, comprising shades and combinations of blue, white, yellow, orange, orange-scarlet and bright rose pink, large flowers with long spurs. Trade pkt., 35c; 1/8 oz., 6oc; $1 / 4$ oz., \$I.00. MRS. SCOTT ELLIOTT'S STRAIN OF LONG-SPURRED HYBRIDS - This strain has received awards whenever exhibited. The blooms are of large size and the spurs very long. Colors range through a most harmonious mass of shades seldom seen in other flowers. There are no crude or jarring tints. I/I6 oz., 6oc; $1 / 8$ oz., \$1.00; 1/4 oz., \$1.75; oz., \$6.00. NEW LONG-SPURRED ROSE QUEENA beautiful variety, producing in great profusion very graceful, large-flowered, long-spurred flowers, shading from light pink to dark rose, with white center and yellow anthers. $1 / 8$ oz., 75c; $1 / 4$ oz., \$1.25.

Chrysantha-A clear long-spurred yellow. 1/8 oz., 35c; $1 / 4$ oz., 6oc.

Caerulea-A beautiful blue. 1/8 oz., $40 c$.

Double Varieties, Mixed-1/8 oz., I5c; $1 / 4$ oz., $25 \mathrm{c}$. Single Varieties, Mixed-1/8 oz., I5c; 1/4 oz., 25 c.

\section{ASPARAGUS}

Plumosus nanus-roo seeds $75 \mathrm{C}$; rooo seeds $\$ 4.50$. Sprengeri (Trailing) - I00 seeds, 25c; 1000 seeds, \$1.25.

\section{BELLIS PERENNIS (Double Daisy)}

I ongfellow-Bright rose. 4 in. Trade pkt. $25 \mathrm{C} ; 1 / 8$ oz., 50c; $1 / 4$ oz., $75 \mathrm{c}$; oz., \$2.50.

Snowball-Pure white. 4 in. Trade pkt., 25c; 1/8 oz., 50c; 1/4 oz., 75c; oz., \$2.50.

Giant Red, Maxima Fl. Pl.-Extra fine. 4 in. Trade pkt., 25c; 1/8 oz., 50c; $1 / 4$ oz., $75 \mathrm{c} ; 0 z$. , \$2.50.

Monstrosa Alba-Giant pure white. Trade pkt. 40c; 1/8 oz., 65c; 1/4 oz., \$1.00; oz., \$3.00.

Monstrosa Rosea-Giant rose. Trade pkt., 40c; 1/8 oz., 65c; 1/4 oz., \$1.00; oz., \$3.00.

Monstrosa-Finest Mixed. Trade pkt., 20c; 1/8 oz., 40c; 1/4 oz., 65c; oz., \$r.9o.

\section{CALENDUla (Pot Marigold)}

H. A. Large double flowers, blooming all summer, closing somewhat at night and opening slightly on cloudy days; flowers borne on long, stiff stems. $2 \mathrm{ft}$.

METEOR-Large double yellow, each petal striped with orange. $1 / 2$ oz., 2oc; oz., 3oc; $1 / 4$ lb., \$1.00; lb., \$3.00.

PRINCE OF ORANGE-Like Meteor, but darker. $1 / 2$ oz., 20c; oz., 30c; 1/4 lb., 9oc; lb., \$3.00. ORANGE KING-Very large, double, dark orange. $1 / 2$ oz., 20c; oz., 30c; $1 / 4$ lb., 9oc; lb., $\$ 2.75$.

DOUBLE SULPHUR-Very large and extremely double flowers of a pleasing sulphur yellow color. $1 / 2$ oz., 20c; oz., 30c; $1 / 4$ lb., \$I.00; lb., \$3.0o.

BALL'S FORCING-This new orange Calendula represents a very great improvement in size, length of stem and fullness of flowers. It has exhibited these superior characteristics uniformly for the past four years. Trade pkt., 20c; $1 / 8$ oz., 35c; $1 / 4$ oz., 6oc; oz., \$1.75.

Finest Mixed-Oz., 3oc; 1/4 1b., 75c; 1b., \$2.25.

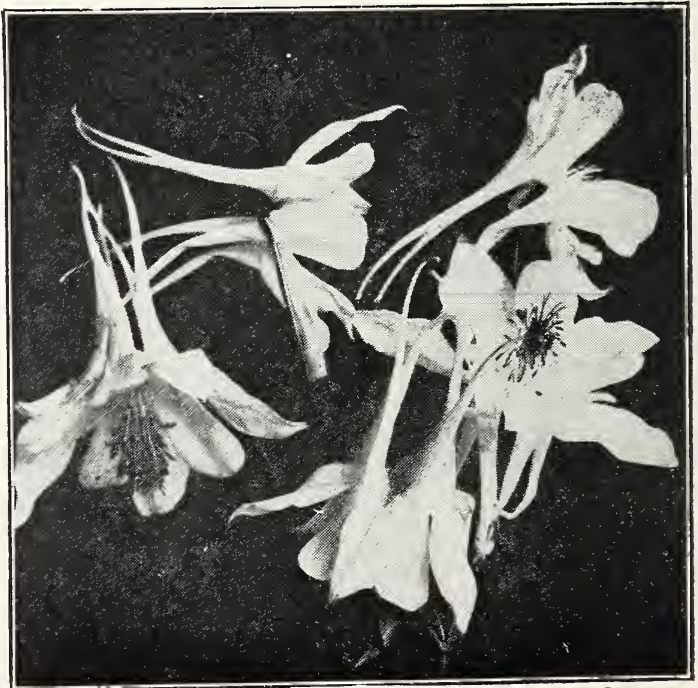

Aquilegia 


\section{CALLIOPSIS (Coreopsis)}

One of the most effective of our hardy annuals; flowers borne on individual stems 18 inches in length. $2 \mathrm{ft}$. GOLDEN WAVE (Drummondi)--Rich, golden yellow with small chestnut brown center; very free. I2 inches. $1 / 4$ oz., $20 \mathrm{c}$; oz., $65 \mathrm{c}$.

CRIMSON KING-A fine dwarf sort, 9 ins. high, color rich velvety crimson-garnet. $1 / 4$ oz., $25 \mathrm{c}$; oz., $75 \mathrm{C}$.

TIGER STAR-Plants not over 9 inches high, flowers of rich reddish-brown, tigered with golden yellow; not unlike some of the orchids. $1 / 4$ oz., 3oc; oz., 9oc.

\section{CAMPANULA (Canterbury Bells)}

Choicest Double Mixed-1/4 oz., 20c; oz., 65 c.

Hardy biennials.

JOHNSON'S PRIZE MIXTURE-An elegant mixture of all the finest classes and colors of single and double and "Cup and Saucer" varieties. 1/8 oz., 30c; 1/4 oz., 5oc.

Calycanthema "Cup and Saucer"-Our mixture includes all the best colors and varieties. $1 / 8$ oz., $25 \mathrm{c} ; 1 / 4$ oz., $45 \mathrm{c}$.

Finest Double Mixed-1/8 oz., 35c; $1 / 4$ oz., 6oc. Finest Single Mixed-1/8 oz., I5C; 1/4 oz., $25 \mathrm{c}$. Pyramidalis, Mixed-Hardy. 1/8 oz., 35c; 1/4 oz., $60 c$.

Carpatica-Hardy. Blue, White or Mixed. $1 / 8$ oz., 20c; 1/4 Oz., 35c.

\section{CANDYTUFT (Iberis)}

Splendid for cut-flowers. H.A. Height I ft. ROSE CARDINAL-Very large umbel of bright rose-cardinal flowers, so prolific that a bed presents an unbroken sheet of bloom. Height, 8 inches. $1 / 8$ oz., I5C; $1 / 4$ oz., $25 \mathrm{C}$; oz., $75 \mathrm{c}$.

EMPRESS or GIANT HYACINTH-FLOWERED-An improved strain, producing immense trusses of pure white bloom, 4 inches in length by 2 inches through. Height, I foot. $1 / 8$ Oz., I5c; 1/4 OZ., 25c; oz., $75 \mathrm{c}$.

LARGE-FLOWERING DWARF, MIXED$1 / 8$ oz., I5C; 1/4 OZ., 2Oc; oz., 5Oc.

White Rocket-Compact spikes. 1/8 oz., Ioc; $1 / 4$ oz., I5C; Oz., 35c.

Odorata-Pure white; most fragrant. $1 / 8$ oz., IOC; $1 / 4$ oz., I5C; Oz., $35 \mathrm{c}$.

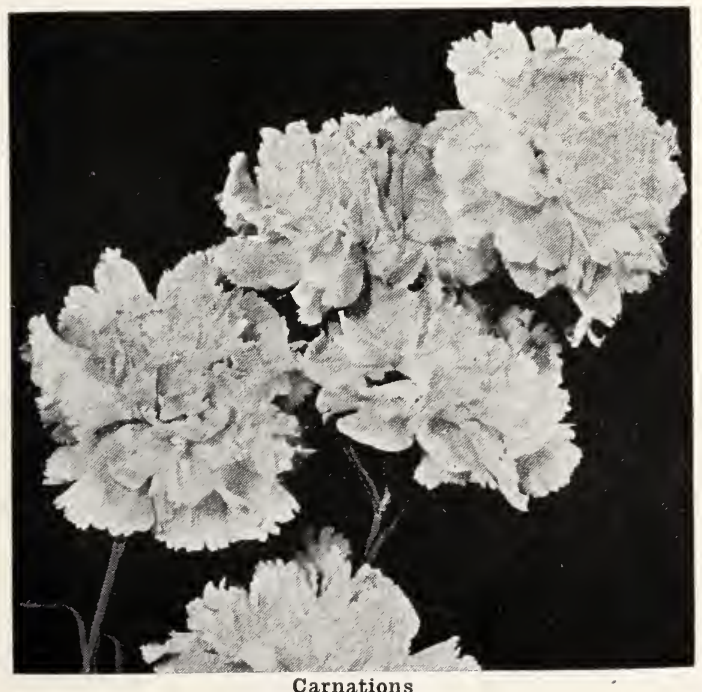

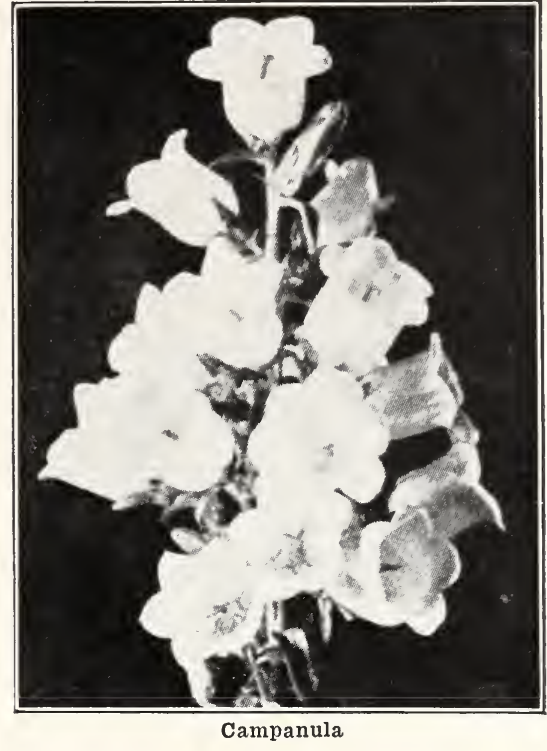

CARNATIONS

Seeds may be sown under glass in the spring, or in open ground, but must be protected in the winter. Half hardy.

GIANT MARGUERITE_-Enormous flowers; colors most varied and brilliant. They come into full bloom in four months from sowing and continue until hard frosts. Our strains are semi-dwarf and strong growers. Heights, I foot. Our mixture is splendid. $1 / 8$ oz., 3oc; $1 / 4$ oz., 5Oc; oz., \$I.75.

MARGUERITE, DOUBLE YELLOW- $1 / 8$ oz., 35c; $1 / 4$ oz., 6oc; oz., \$I.90.

JOHNSON'S PEERLESS MIXTURE-All bloom the first summer. A very choice mixture including all superb sorts. $1 / 8$ oz., 400 ; $1 / 4$ oz., 70c; oz., \$2.50.

CHABAUD'S NEW GIANT PERPETUALComes into bloom in a little over four months from seed; extra-large size; fine range of colors; is very sweet-scented. Mixed colors, $1 / 8$ oz., 35c; $1 / 4$ oz., 6oc; oz., \$1.90.

RED GRENADIN-Double red flowers; no outdoor Carnation can equal it. $1 / 8$ oz., $35 \mathrm{C}$; $1 / 4$ oz., 6oc; oz., \$2.00.

CHABAUD'S GIANT IMPROVED-1/8 oz., $40 \mathrm{OC}$; $1 / 4$ oz., $75 \mathrm{c}$; oz., \$2.50.

\section{CELOSIA or COCKSCOMB}

Attractive annual. The crested heads of flowers resemble a cock's comb and the plumed heads are like great feathers. Sow the seed directly in the garden or start early and transplant. Make fine lot plants.

Thompsoni magnifica (Ostrich Plume)-Mixed colors. $1 / 8$ oz., 25C; $1 / 4$ oz., 40C; OZ., \$1.00.

Gold Plume-Yellow. 1/8 oz., I5C; 1/4 oz., 25c; oz., $75 \mathrm{c}$.

Fire Plume-Scarlet. $1 / 8$ oz., I5c; $1 / 4$ oz., $25 \mathrm{C}$; oz., $75 \mathrm{c}$.

Glasgow Prize (Crested Type)—1/s oz., 25C; 1/4 oz., 40C; Oz., \$I.00.

Finest Dwarf, Mixed-1/8 oz., 25c; 1/4 oz., 40c: oz., \$1.0o. 


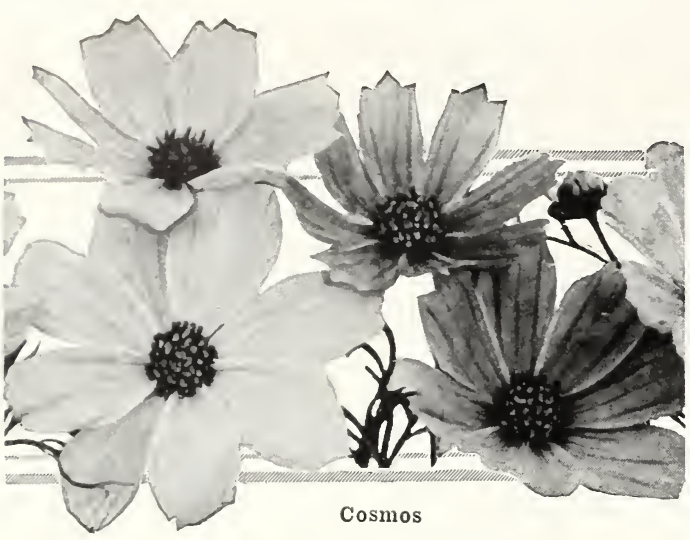

HOTKAPS

They are like small hothouses, that protect plants from frost, wind, rain and insects. See page 20 for description and prices

\section{CENTAUREAS}

The different varieties of this popular annual include such favorites as the Bachelor's Buttons or Cornflowers, and Sweet Sultans, old-fashioned flowers of easiest culture. Height, 2 feet. Bachelor's Button, Mixed-1/4 oz., I5c; oz., 40c; $1 / 4$ lb., 9oc.

Cyanus Emperor William-Blue. 1/4 oz., I5C; oz., 40c; 1/4 lb., 9oc.

Double Blue-1/4 oz., 25c; oz., 75c; 1/4 lb., \$2.00.

\section{Giant-flowering Sweet Sultans (Centaurea imperialis)}

The blooms are borne on long stems. Plants of the easiest growth; very showy in the garden all summer long.

Giant Mixed Colors-An elegant assortment of colors. 1/4 oz., 25c; oz., 75c; 1/4 lb., \$2.00.

Johnson's Choice Mixture-A grand mixture of all the Bachelor's Buttons and Giant Sweet Sultans. 1/4 OZ., 25c; oz., 75c; 1/4 lb., \$2.00.

\section{White-leaved Centaureas (Dusty Millers)}

Silver-foliaged plants, extensively used for edging, hanging-baskets, etc.

CANDIDISSIMA-Very thick, broadly cut, silvery white leaves. Height, I foot. $1 / 8 \mathrm{oz}$. 40C; $1 / 4$ OZ., 70c; Oz., \$2.50.

GYMNOCARPA-Leaves fern-like; silvery gray color. Fine for borders. Height, I $1 / 2$ ft. $1 / 8$ oz., $20 \mathrm{c}$; 1/4 Oz., 3Oc; oz., $75 \mathrm{c}$.

\section{CINERARIA}

A favorite free-blooming greenhouse plant, with flowers of great richness and diversity of colors. Cinerarias bloom during the winter and spring months and can be planted out in summer. The plants thrive best in a mixture of loam, leafmould, and sand.

Johnson's Large-Flowering-Prize varieties. I/32 oz., \$3.75; i/ 16 oz., \$7.00.

Maritima (Dusty Miller)—1/4 oz., 20c; oz., $50 \mathrm{c}$.

\section{cosmos}

NEW DOUBLE CRESTED-A new class, producing beautifully crested flowers most striking in appearance. The graceful foliage and the starry crested blooms lend themselves to the most artistic arrangement.

Finest Mixed-1/8 oz., 40c; 1/4 oz., 75c; oz., \$2.75.

\section{Extra Early Giant Cosmos}

$1 / 4$ Oz. Oz. $1 / 4 \mathrm{lb}$.

Early Crimson-Very rich $\ldots .$. \$o.15 \$0.40 \$1.00 arly Pink-A pretty shade... .I5 $\quad .40 \quad$ I.00 Early Pure White ............ .I5 .40 1.00

\section{Autumn Giant Cosmos}

This popular autumn flower bears gigantic wers, with wide, overlapping petals, making stems. This type produces the largest and Giant Pink-A beautiful deep rosy pink. $1 / 4 \quad \mathrm{oz}$. c; Oz., 40c; 1/4 lb., \$I.00. 40c; $1 / 4$ lb., \$1.0o.

Giant Mixed-Contains an even proportion of the three colors. 1/4 oz., I5c; oz., 40c; 1/4 lb.

\section{COLEUS}

EXTRA FINE HYBRIDS-A. Our strain produces the finest colored, most attractive and April. I-I6 oz., $75 \mathrm{c} ; 1 / 8$ oz., \$I.40.

\section{DIANTHUS-PINKS}

The annual and biennial sorts of Dianthus lower freely the first year from seed. Quite bloom the second year than the first. Sow in inches apart in the row. Blooming season June Finest HEDDEWIGII-Double Fringed Japan Pink. Seed saved from the best double flowers only. IREBALL_Compact, free-flowering plants. $50 \mathrm{C}$

JOHNSON'S DIANTHUS MIXTURE-Finsingle and double sorts, all good colors. Fine for garden display and cut flowers. $1 / 8$ oz., 20c; $1 / 4$ Oz., 35c.

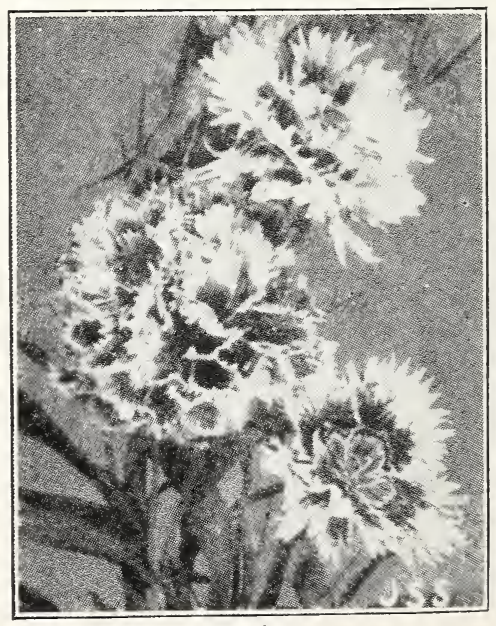

Dianthus 


\section{Hardy Pinks}

PHEASANT'S EYE, or JUNE PINK-Sometimes called grass pink; fine hardy perennial plant for borders and for massing. Flowers single, beautiful and fragrant. Succeeds best in full sun. Plant is of the low growth. $1 / 4 \mathrm{oz}$., 20c; oz., 6oc.

\section{DELPHINIUM}

Hardy Perennial Larkspur

WREXHAM (Hollyhock Strain)-Has spirelike spikes of great length, of rich and varied tints; long blooming period, some varieties well into August; resemble hollyhocks.

Mixed-1/16 oz., 6oc; 1/8 oz., \$1.00; 1/4 oz., \$1.75. NEW GIANT-FLOWERING HYBRIDSThese magnificent hybrids produce splendid spikes of immense flowers, semi-double and double, from 2 to 5 feet in length. The colors are very beautiful, ranging from pure white through all the shades of lavender and blue. Mixed colors, $1 / 8$ oz., 35c; $1 / 4$ oz., 6oc; oz., $\$ 2.00$.

BELLAMOSA-A dark blue form of the light blue Belladonna. It is identical in habit of growth and freedom of bloom. 1/8 oz., 4oc; 1/4 oz., 7oc; oz., \$2.50.

BELLADONNA-Light sky-blue flowers, with light centers; a very fine variety. Height, $4 \mathrm{ft}$. $1 / 8$ oz., 5oc; $1 / 4$ oz., 85c; oz., \$3.00.

\section{ESCHSCHOLTZIA (California Poppy)}

GOLDEN WEST-Early and continuous bloomer. Magnificent flowers of gigantic size. Color intense shining yellow and orange. The state flower of California. 1/4 oz., I5c; oz., 40c. Finest Double Mixed-1/4 oz., 25c; oz., $75 \mathrm{c}$. Finest Single Mixed-1/4 oz., I5c; oz., 40c.

\section{DIGITALIS (Foxglove)}

Ornamental, hardy perennial plants of stately growth. Old garden favorites for the border, producing their attractive flowers in great masses during June and July. The plants succeed well even in poor soil if given half-shady location. Spikes are often 3 to 5 feet long and thickly strung with scores of thimble-shaped flowers of various colors.

Johnson's Special Mixture-The very fine assortment of different varieties and colors. Trade pkt., 20c; 1/4 oz., 30c; oz., \$1.0o.

Gloxiniaeflora-Mixed colors. 1/4 oz., 25c; oz., $85 \mathrm{c}$.

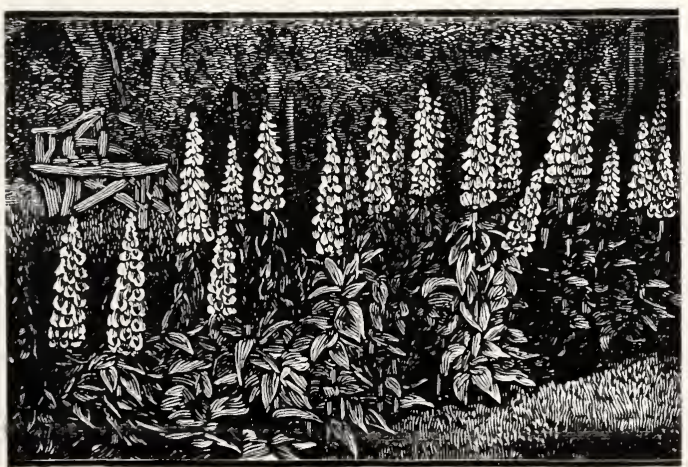

Foxglove

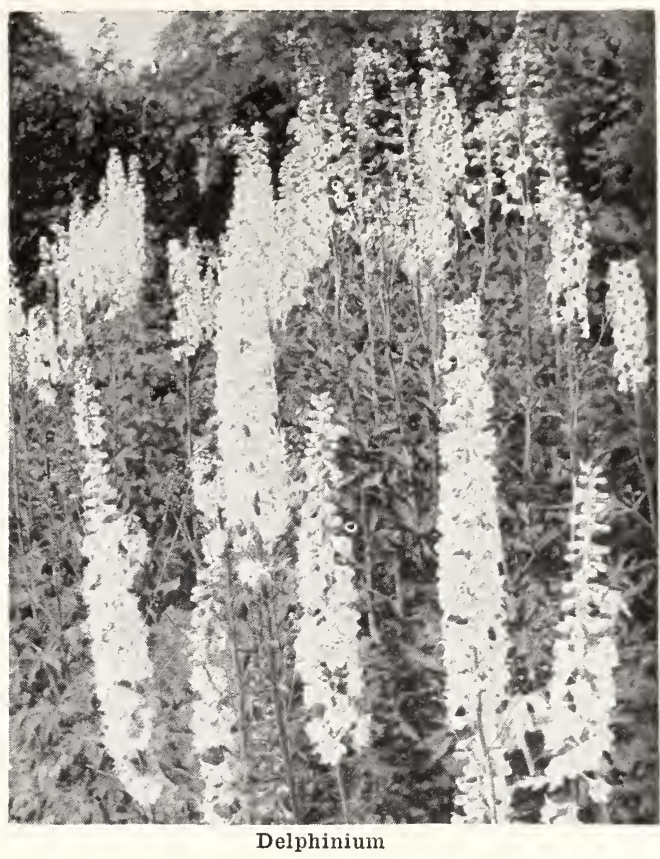

\section{FEVERFEW (Matricaria)}

Free-flowering annuals about I foot high; very compact and bushy. Splendid for beds and borders; also fine as cut-flowers or for pots. $1 / 4$ oz., 20c; oz., 5oc.

\section{GAILLARDIA (Blanket Flower)}

FINEST SINGLE ANNUAL, MIXED-1/4 oz., I5C; oz., 4OC; 1/4 lb., \$r.25.

FINEST DOUBLE ANNUAL, MIXED (G. Lorenziana)-All the best double-flowering varieties in richest mixture. Splendid for bouquets. $1 / 4$ oz., I5c; oz., 40c; $1 / 4$ lb., $\$ 1.25$.

GRANDIFLORA HYBRIDS, FINEST MIXED-One of the best perennials; is in continuous bloom from June until frost. The large flowers are a magnificent combination of red and yellow. Splendid to cut for vases. 1/4 oz., I5c; oz., 40c; 1/4 lb., \$1.0o.

GRANDIFLORA COMPACTA-A compactgrowing variety similar in bloom to the Grandiflora Hybrids, but grows only about is inches high. Its flowers are of the richest colors, and the stems are long. 1/4 oz., 25c; oz., 6oc.

PORTOLA HYBRIDS-A new strain of very large size, with colors ranging through shades of bronzy red and the petals tipped with gold. $1 / 8$ oz., $40 \mathrm{c} ; 1 / 4$ oz., $75 \mathrm{c}$.

\section{GYPSOPHILA}

\section{(BABY'S BREATH)}

Hardy annual. The fiowers are small. starlike, and borne in feathery sprays which are highly esteemed for cut flowers, as they lend a most graceful effect when combined in bouquets with Sweet Peas or other flowers. Successive plantings should be made to furnish a continuous supply of flowers.

Elegans-The annual variety. White. $1 / 2$ oz., I5c; oz., 25c; 1/4 lb., 75 c.

Paniculata-The perennial kind. 1/4 oz., 3oc; oz., 85c. 


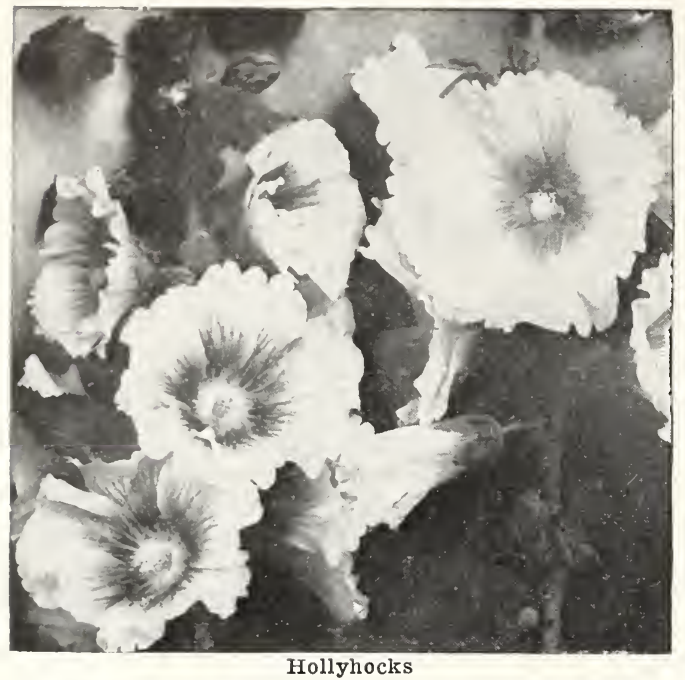

HELICHRYSUM (Straw Flower)

Monstrosum F1. Pl.-One of the best of the "ever-lastings." They succeed in any good garden soil.

Golden Globe-Golden yellow.

Canary Yellow-Clear yellow.

Silver Globe-Glistening white.

Fireball-Fiery red.

Crimson-Striking color.

Rose-Carmine Shades.

Salmon-Rosy salmon.

Violet-Very rich color.

Salmony Red-Beautiful.

Scarlet-Very showy.

White-Pure white.

Prices of above, separate colors, $1 / 8$ oz., I5c; $1 / 4$ Oz., 25c; Oz., $75 \mathrm{c}$.

Mixed-A mixture of the above and other colors. $1 / 8$ oz., I5C; $1 / 4$ oz., 20c; oz., 65 c.

\section{HOLLYHOCKS}

Double Black Double Rose-Pink

Double Lemon-Yellow Double Crimson

Double White Double Scarlet

\section{Double Salmon}

Any color, $1 / 8$ oz., 25c; $1 / 4$ oz., 35c.

JOHNSON'S PRIZE MIXTURE-This is our best mixture. It is composed exclusively of the finest double-flowering varieties. It contains not only the above elegant colors, but also innumerable other shades. $1 / 8$ oz., 20c; $1 / 4$ oz., 30c.

\section{HELIOTROPE}

LEMOINE'S GIANT HYBRIDS-Grand flowers, double the size of the older sorts. Bushes compact, about 18 inches high; heads of mammoth blossoms often measure a foot across. Deliciously fragrant. Mixed, including Purple, White, Lavender, and Blue. $1 / 8$ oz., $35 \mathrm{c} ; 1 / 4 \mathrm{oz}$., $60 c ;$ oz., \$2.00.

All Sorts Mixed-In best assortment; all shades, both light and dark. A very desirable strain. $1 / 8$ oz., $25 \mathrm{C} ; 1 / 4$ oz., 4OC; oz., \$1.25.

\section{LARKSPUR DELPHINIUM}

\section{Larkspur-Annual Varieties}

Well-known annuals of great beauty and noted for richness of colors particularly in blue shades. Easily grown. Much prized for cut flowers. Annual Larkspurs should be planted extensively in every garden.

DOUBLE TALL ROCKET-All colors mixed. 2 feet high. $1 / 8$ oz., 20c; $1 / 4$ oz., 3oc; oz., 75 c. DOUBLE DWARF ROCKET-Plants grow I 2 to 15 inches tall. Finest mixed. 1/8 oz., 20c; $1 / 4$ oz., 3oc; oz., 75c.

EXQUISITE-Charming new double flowered Larkspur with tall spikes of a soft pink shade. $1 / 8$ oz., 35c; $1 / 4$ oz., 6oc; oz., $\$ 2.00$.

TALL DOUBLE-Dark blue. 1/8 oz., 20c; 1/4 oz., 3Oc; oz., 85c.

JOHNSON'S LARKSPUR MIXTURELovely annual sorts, fine varieties and colors. Plant them for cut flowers. $1 / 8$ oz., 20c; $1 / 4$ oz. $30 \mathrm{c} ;$ oz., $85 \mathrm{c}$.

\section{LUPINUS or LUPINES}

Free-flowering annuals of easy culture; long, graceful spikes of rich colored, pea-shaped flowers. Fine for borders, large beds and for cutting. Prefers a little shade. 2 feet. Lupins belong to the class of old-fashioned flowers that are now coming into vogue again.

Annual Mixed-Pure white, light and dark blue, rose and bright pink. 1/4 oz., 2oc; oz., 5oc.

Perennial Mixed-The hardy strain of Lupines. Beautiful colors. Mixed, $1 / 4$ oz., 20c; oz., 5oc.

\section{LOBELIA}

CRYSTAL PALACE COMPACTA-Best dark blue sort for edgings and carpet bedding. $1 / 8$ oz., 4OC; 1/4 oz., 7oc; oz., \$2.50.

GRACILIS-A trailing variety, fine for hanging-baskets, vases, and window-boxes. Light blue. $1 / 8$ oz., I5C; $1 / 4$ oz., $25 \mathrm{c}$.

MIXED COMPACTA SORTS-A very fine mixture of all the best varieties for edgings and bedding. $1 / 8$ oz., $35 \mathrm{c} ; 1 / 4$ oz., 6oc.

\section{MARIGOLD-TAGETES AFRICAN MARIGOLDS}

Lemon Ball-1/4 oz., 20c; oz., 6oc; $1 / 4$ lb., \$2.00. Orange Ball-1/4 oz., 20c; oz., 6oc; 1/4 lb., \$2.00. Double, Tall, Mixed-1/4 oz., 20c; oz., 50c; $1 / 4$ lb., \$1.0o.

Dwarf, Mixed-1/4 oz., I5c; oz., 40c; $1 / 4$ lb., \$1.0o.

\section{French Marigolds}

Legion of Honor-1/4 oz., I5c; oz., 40c; 1/4 lb., \$1.0o.

Tall, Double, Mixed-1/4 oz., I5c; oz., 40c; 1/4 lb., \$I.oo.

Dwarf, Double, Mixed-1/4 oz., I5c; oz., 4 oc; $1 / 4$ lb., \$1.0o.

Tagetes signata pumila-Dwarf. Very striking for edgings. $1 / 8$ oz., $25 \mathrm{C} ; 1 / 4$ oz., $40 \mathrm{OC}$; Oz., \$I.25.

\section{MIGNONETTE (Reseda)}

Golden Machet-Golden yellow-1/4 oz., 25c; oz., 65 c.

Odorata-1/4 oz., Ioc; oz., $20 c$.

Red Goliath-1/4 oz., 30c; oz., \$1.00.

Finest Mixed-1/4 oz., 20c; oz., 5oc. 


\section{MYOSOTIS (Forget-me-not)}

PALUSTRIS-(True Forget-me-not). Beautiful blue. Height, 6 inćhes. $1 / 8$ oz., $35 \mathrm{c} ; 1 / 4$ oz., $60 c ;$ oz., \$2.00.

ALPESTRIS-Bright blue. $1 / 8$ oz., 35c; $1 / 4$ oz., $60 c$; oz., \$2.00.

ALPESTRIS ROSEA-Pink. $1 / 8$ oz., $35 \mathrm{c} ; 1 / 4$ oz., 6oc; oz., \$2.00.

SEMPERFLORENS-Splendid dwarf Forgetme-not; will thrive in sun or shade, covered from early to late with beautiful blue flowers. $1 / 8$ oz., 35c; $1 / 4$ oz., 6oc; oz., $\$ 2.00$.

FINEST MIXED-A mixture of all the finest sorts. 1/8 Oz., I5C; 1/4 oz., 25c; oz., 75c.

\section{NASTURTIUMS}

JOHNSON'S SUPERB TALL MIXED-This is a fitting companion mixture to Johnson's Superb Dwarf collection. It contains the choicest colors in greatest variety. Oz., Ioc; 4 ozs., $30 \mathrm{c} ; 1 \mathrm{~b} ., 85 \mathrm{c}$.

JOHNSON'S SUPERB DWARF MIXEDOne of the choicest collections of really highclass varieties not commonly found in mixtures. It contains many high priced named kinds of superb colors. Oz., I5c; 4 ozs., 35c; lb., \$1.oo. VARIEGATED VARIETIES - Variegatedleaved, mixed. Oz., I5c; 4 ozs., 50c.

\section{JOHNSON'S SUPERB PANSIES}

\section{(Heartsease)}

Finest Show Pansies. Enormous Flowers. JOHNSON'S UNIVERSAL MIXTUREThis is the finest mixture possible to make as regards size, texture and colorings. Trade pkt., 500 ; $1 / 8$ oz., \$1.00; oz., \$6.00.

GIANT RUFFLED MASTERPIECE-Giant curled and ruffled Pansies. Very beautiful, containing the richest combination of colors. Trade pkt., $25 \mathrm{C} ; 1 / 8$ oz., $75 \mathrm{c}$; oz., $\$ 4.5$.

BUGNOT'S SUPERB BLOTCHED-Flowers of enormous size. The shadings comprise tints of red, bronze and brown not found in any other mixture. Trade pkt., $25 \mathrm{c}$; $1 / 8$ oz., $75 \mathrm{c}$; oz., \$4.50.

CASSIER'S GIANT - The largest-flowered class of blotched Pansies. Trade pkt., 25c; $1 / 8$ oz., $75 \mathrm{c} ;$ oz., $\$ 4.5$.

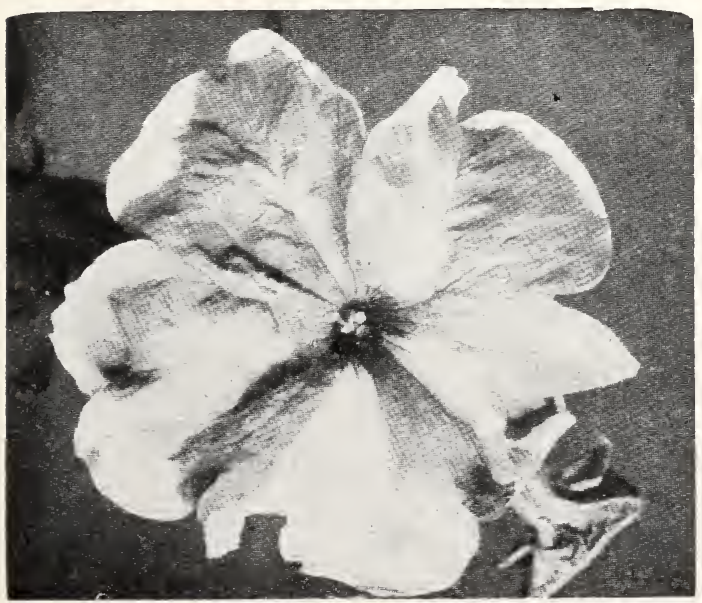

Petunjas

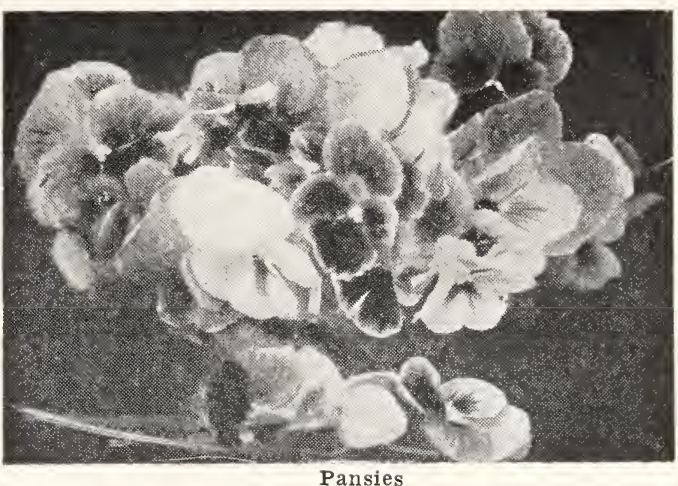

\section{Giant Pansies in Separate Colors}

We are offering Giant Pansies in separate colors, that you may perfect your color scheme with these dainty flowers.
Giant Red
Giant White
Giant Blue
Giant Black
Giant Yellow
Giant Purple

Any of above Giant Pansies in separate colors, $1 / 8$ oz., $40 \mathrm{OC}$; $1 / 4$ oz., $75 \mathrm{C}$; oz., $\$ 2.75$.

\section{PETUNIAS \\ Large Flowering Petunias}

NOTE-All Large-flowering and Double Petunias should be started indoors and transplanted. Only about 40 to 60 per cent of Double Petunia seed make double flowers. Give the small, weak plants great care; they make the finest bloom.

JOHNSON'S SUPERB SINGLE MIXED-Flowers most varied in colors and markings, beautifully ruffled, fringed and of enormous size. I-32 oz., 75C; I-I6 oz., \$I.25; $1 / 8$ oz., $\$ 2.00$. DWARF GIANTS OF CALIFORNIA - A dwarf, sturdy-growing type especially suited to pot culture. Beautifully ruffled and fringed, with open, well-marked throats. A mixture of most desirable colors. I-64 oz., \$2.00; I-32 oz., \$3.50; I-16 OZ., \$6.50.

GIANTS OF CALIFORNIA-These Petunias are of great beauty and luxuriance, including fringed and deep-throated sorts in endless colors, veinings and markings. $\mathrm{I}-32$ oz., $75 \mathrm{C} ; \mathrm{I}-\mathrm{I} 6$ oz., \$1.35; 1/8 oz., \$2.50; $1 / 4$ oz., \$4.50.

COPPERY RED-Very new shade with giant ruffled flowers and bronze throats. I-64 oz., $\$ 2.00 ;$ I-32 oz., $\$ 3.50$.

RUFFLED GIANTS-The flowers of this strain are of extraordinary size and great substance; the edges of the blooms ruffled. I-64 oz., \$1.0o; I-32 oz., \$I.75; I-16 oz., \$3.25.

JOHNSON'S SUPERB DOUBLE MIXEDOur best mixture of all the large-flowering double varieties including striped, blotched, and fringed sorts. I-64 oz., \$3.00; I-32 oz., \$5.50. PRIDE OF PORTLAND-A deep rose-pink with throat varying from white to rich yellow. Very large, round flower with finely fringed edge. I/I6 oz., \$2.75; 1/8 oz., \$5.00.

THEODOSIA-The all-purpose single ruffled Petunia. Color is a rosy pink, with a golden throat which contains minute stripes. It is wonderfully free bloomer and is adapted for either bedding or pot culture. I.64 oz., $\$ 2.25 ; \mathrm{I}-32$ oz., $\$ 4.00$; I-16 oz., \$7.00. 


\section{Bedding Petunias}

Rosy Morn-I-I6 oz., 25c; 1/8 oz., 45c; 1/4 oz., $80 c$; oz., \$2.75.

Rose of Heaven-I-I6 oz., 25c; 1/8 oz., 40c; 1/4 oz., 7oc; oz., \$2.50.

Howard's Star-Fine for baskets and vases. I-I6 OZ., I5C; 1/8 oz., 25c; 1/4 oz., 4OC; oz., \$I.40. Striped and Blotched, Single-I-I6 oz., I5C; $1 / 8$ oz., 25c; 1/4 oz., 40c; oz., \$1.40.

Finest Single Mixed-I-I6 oz., IOc; 1/8 oz., I5c; $1 / 4$ Oz., 25c; Oz., $75 \mathrm{C}$.

\section{Balcony Petunias}

fine large and free-flowering type of single Petunias, especially suited for window boxes, vases, hanging baskets, etc. The many branches are of trailing habit and the large flowers are produced very freely all season.

White-Pure white.

Red-Very brilliant.

Rose-Bright rose,

Blue-Purplish blue.

white throat.

Mixed-All colors.

Any of above Balcony Petunias, I-I6 oz., 35c; 1/8 oz., 6oc; 1/4 oz., \$I.Io.

\section{PHLOX DRUMMONDI}

Seed may be sown in the open ground any time after danger from frost is past.

Bright Rose-1/8 oz., 25c; 1/4 oz., 40c; oz., \$1.40. Brilliant Scarlet-Very showy. 1/8 oz., 25c; 1/4 oz., 40c; oz., \$1.40.

Crimson-Brilliant and effective. $1 / 8$ oz., $25 \mathrm{c}$; r/4 Oz., 4Oc; oz., \$I.40.

Pure White-1/8 oz., 25c; 1/4 oz., 40c; oz., \$I.40. Yellow-Distinct. $1 / 8$ oz., 25c; $1 / 4$ oz., 4Oc; oz., \$.40.

Johnson's Prize Mixture-1/8 oz., 25c; 1/4 oz., 40c; oz., \$I.40.

Drummondi Mixed-A very fair quality mixture. $1 / 4$ oz., 25c., oz., 75c.

Mixed Star-Shaped-Long, pointed petals, which give the flowers a star-like appearance. $1 / 8$ oz., 20c; 1/4 oz., 30c; Oz., \$I.00.

Hardy Perennial Phlox (P. decussata)-Hardy herbaceous perennial and quite distinct from the varieties of Phlox Drummondi offered above, which are annuals. I-I6 oz., 25c; 1/8 oz., 45c; $1 / 4$ oz., 8oc; oz., \$3.0o.

\section{POPPIES}

\section{SINGLE ANNUAL VARIETIES}

GIANT SHIRLEY, SILK or GHOST POP. PY-No flower is so exceedingly graceful and decorates our gardens with such brilliancy of color as this poppy. Plants about 18 inches tall. $1 / 4$ oz., $15 \mathrm{C} ; 1 / 2$ oz., $25 \mathrm{C}$; oz., $40 \mathrm{Oc}$.

American Legion-1/8 oz., I5c; $1 / 4$ oz., $25 \mathrm{c}$; oz., $65 \mathrm{c}$.

Tulip Poppies-1/4 oz., I5c; oz., 4oc.

\section{DOUBLE ANNUAL POPPIES}

CARNATION-FLOWERED-Very large, double, slightly fringed flowers in brilliant colors. Height 2 feet. All colors mixed. $1 / 4$ oz. I5c; $1 / 2$ Oz. $25 \mathrm{C} ;$ oz. $40 \mathrm{C}$.

PEONY-FLOWERED-Imposing double, globular flowers resembling double peonies. Splendid range of colors. Mixed, $1 / 4$ oz., I5c; oz., $35 \mathrm{c}$.
JOHNSON'S DOUBLE POPPY MIXTURE -All the good varieties and also novelties are to be found in this superfine mixture of double Poppies. These will make a gorgeous showing; use them for large beds and for the border. 1/4 oz., I5c; oz., 35c; 1/4 lb., \$1.25.

\section{Perennial Poppies}

ICELAND POPPY (Nudicaule)-Plants are of graceful habit, with fern like foliage, producing their brilliant flowers in profusion all Summer. Height 18 inches. Mixed. $1 / 8$ oz., 2oc; $1 / 4$ oz., 3oc; $1 / 2$ oz., 5oc; oz., 9oc.

ORIENTAL POPPY-Gorgeous, showy, flowers, measuring 6 to 7 inches across, of dazzling, brilliant colors, mostly shades of red. Height 2 feet. Mixed colors. $1 / 8$ oz., 2oc; $1 / 4$ oz., 35c; oz., \$1.25.

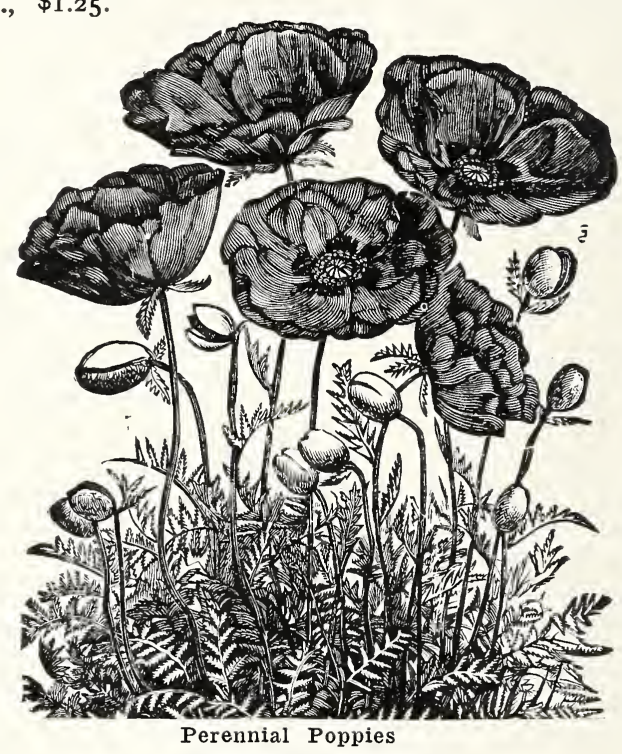

PORTULACA

H. A. A very free-flowering plant; excellent for borders and rockeries and frequently used for bedding. Seed sown in May will bloom during July and a continuous display of flowers will be had until frost. 6 in.

Large Flowering Single Mixed—1/8 oz., ${ }_{5}$ c; $1 / 4$ oz., 25c; oz., $75 \mathrm{c}$.

Large Flowering Double Mixed-1/8 oz., 35c; 1/4 oz., 6oc; oz., 2.00 .

\section{PYRETHRUM}

Most attractive hardy perennials which have become very popular. Valuable border plants with many stems about 2 feet high, each surmounted with handsome flowers in the brightest shades of rose, flesh-pink, crimson, etc. In bloom a long time and are splendid as cut-flowers.

Roseum-Bright rose. I/I6 oz., 35c; 1/8 oz., 5oc; $1 / 4$ oz., 9oc; oz., $\$ 3.40$.

Album-White. I/I6 oz., 35c; $1 / 8$ oz., $50 \mathrm{cc} ; 1 / 4$ oz., 9oc; oz., \$3.40.

Atrosanguineum-Blood-red. I/I6 oz., $35 \mathrm{c} ; 1 / 8$ oz., 6oc; $1 / 4$ oz., \$1.10; oz., \$4.00.

Single Hybrids-This mixture contains the very largest flowering and choicest varieties. I/I6 oz., $20 \mathrm{OC} ; 1 / 8$ oz., 35c; $1 / 4$ oz., foc; oz., $\$ 2.00$. 


\section{PRIMUlA (Primrose)}

A good variety for pot plants for decorative use, blooming from autumn to spring. May also be used outdoors. The grandiflora varieties are the freest flowering, but lack the very large individual blooms of the newer Gigantea type.

OBCONICA GRANDIFLORA, Largeflowering Hybrids-Lovely and profuse blooming Primrose, bearing on long stems large heads of beautiful flowers, white, tinged lilac and rose shades. I/I6 oz., 80c; 1/8 oz., \$I.5O.

\section{SALVIA (Flowering Sage)}

The plants may be started in a box in the house or in the hotbed and when the weather becomes warm transplant in the garden. Height $I \frac{1}{2}$ to 3 feet. May be used as a hedge with striking effect.

SPLENDENS GRANDIFLORA (Scarlet Sage)-Gorgeous plants; numerous spikes of intensely vivid scarlet flowers 10 to 12 inches in length. Continues to flower profusely all summer and fall; of easy growth. The most popular Salvia in cultivation. I / 6 oz., 20c; 1/8 oz., 35c; 1/4 oz., 6oc; oz., $\$ 2.00 ; 1 / 4$ lb., $\$ 6.50$.

BONFIRE-Plants form healthy bushes about 2 feet high by 2 feet across. Spikes grow erect and stand clear above the foliage completely covering the plant, and are of a most brilliant, dazzling scarlet. One of the finest sorts. I/I6 oz., $25 \mathrm{c}$; $1 / 8$ oz., $45 \mathrm{c} ; 1 / 4 \quad \mathrm{oz}$., $80 c$; oz., \$3.00; 1/4 lb., \$9.00.

AMERICA (Globe of Fire)-A free and continuous bloomer. The uniformity in habit of growth makes it valuable for bedding or planting in line. Height, I $1 / 2$ feet. I-I 6 oz., $35 \mathrm{C} ; 1 / 8$ oz., 6oc; 1/4 oz., \$I.10; oz., \$4.25.

ZURICH-Compact-growing sort, forming handsome, symmetrical bushes, I5 to 18 inches tall, which are completely covered with scarlet flower-spikes. A little beauty. I-I6 oz., $35 \mathrm{c}$; $1 / 8$ oz., 6oc; 1/4 oz., \$I.10; oz., \$4.00.

\section{SALPIGLOSSIS (Painted Tongue)} JOHNSON'S FINEST MIXED-The Salpiglossis is one of the most popular and favorite annuals. It is of the easiest culture. Especially is it noted for its beautiful, almost orchidlike blooms. Our mixture is unsurpassed, containing every desirable color and shade of the large-flowering varieties. Height, $1 \frac{1}{2}$ feet. $1 / 4$ oz., 25c; oz., 75c; 1/4 lb., \$2.50.

\section{SCHIZANTHUS (Butterfly Flower)} JOHNSON'S FINEST MIXED-Popularly called the "Poor Man's Orchid." It grows from I to $I \frac{1}{2}$ feet tall with fine fern-like foliage, begins to flower early and produces masses of oddly marked and queerly shaped blooms in various shades of blue, purple, and pink, and some pure white. $1 / 8$ oz., I5c; $1 / 4$ oz., $25 \mathrm{C}$; oz., $75 \mathrm{c}$.

\section{STATICE}

It produces a beautiful effect. Is also very effective when used in the border or rockery.

True Blue.

White.

Rosea Superba.

Mixed.

Any of ahove Statices, $1 / 4$ oz., 25c; oz., $75 \mathrm{c}$.

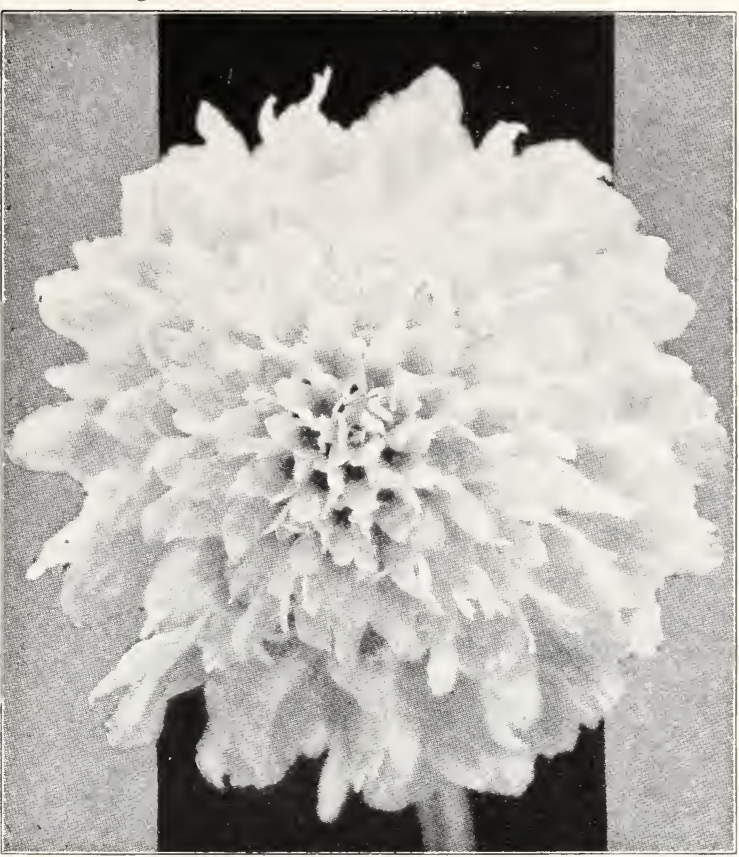

Shasta, Scabiosa

\section{SCABIOSA}

Sweet Scabiosa; Mourning Bride; Pin-Cushion Flower

Seed can be sown any time in the spring after danger from frost is past. The plants grow about $2 \frac{1}{2}$ feet high and come into bloom early in June, continuing without interruption until the hard frosts of autumn.

SHASTA-A pure glistening white of enormous size. The magnificent flowers, often measuring $3 \frac{1}{2}$ inches across, are borne on long, stiff stems, which makes them valuable as cut flowers. $1 / 8$ oz., 25c; $1 / 4$ oz., $40 \mathrm{c}$.

JOHNSON'S IMPROVED LARGE-FLOW. ERING, FINEST MIXED-A very fine mixture, containing all the finest large-flowering double sorts. All colors. 1/4 oz., 25c; oz., 6oc. Azure Fairy-Exquisite sky-blue. 1/4 oz., 25c; oz., 65 c.

Fiery Red-Very striking. 1/4 oz., 25c; oz., 65 c. Golden Yellow-Very fine color. $1 / 4$ oz., 25c; oz., 65 c.

Flesh-Deeply flushed. 1/4 oz., 25c; oz., 65c.

Lilac-One of the best. $1 / 4$ oz., 25c; oz., $6{ }_{5} \mathrm{c}$.

Cherry-Red-Magnificent. 1/4 oz., 25c; oz., $65 \mathrm{c}$.

Black Prince-Exceedingly attractive. $1 / 40 z$., 25c; oz., 65c.

Caucasica-Grand hardy perennial, 3 feet high; large lilac-blue flowers; splendid for cut-flowers. I-I6 oz., 3Oc; $1 / 8$ oz., 5Oc; $1 / 4$ oz., $85 \mathrm{c} ;$ oz., $\$ 3.25$.

\section{STOKESIA}

CYANEA (Cornflower Aster) - A valuable hardy perennial bedding plant. Plants large, I 8 to 20 inches high, with bachelor's button-like, light lavender-blue flowers, several inches in diameter, from July until late in October. I-I6 oz., 20c; $1 / 8$ oz., 30c; $1 / 4$ oz., 55c; 0z., \$2.00. 


\section{STOCKS (Gilliflower)}

Indispensable for bedding, borders, massing, or pot culture. Large-flowering Double "Cut-andCome-Again" Varieties.

JOHNSON'S FINEST MIXED-This is our very best mixture of large-flowering Stocks. The perfectly double flowers embrace every color and shade. I-I6 oz., I5c; I-8 oz., 30c; 1/4 lb., $50 \mathrm{c}$. JOHNSON'S GIANT PERFECTION, MIXED-Long spikes of double flowers. I/I6 oz., 20c; $1 / 8$ oz., 35c; $1 / 4$ oz., 6oc.

\section{SWEET WILLIAM}

(Dianthus barbatus)

A well-known, attractive biennial which flowers the second season from seed. Sow outdoors in May, and transplant in August.

\section{Single White \\ Single Crimson \\ Single Black-Red}

\section{Single Finest Mixed \\ Single Dark Crimson \\ Single Red, Margined} White

Any of above, 1/8 oz., Ioc; $1 / 4$ oz., I5c; oz., $50 c$.

Double White

Double Crimson

Double Black-Red

Double Pink

Double Finest Mixed

Any of above, 1/8 oz., I5c; 1/4 oz., 25c; oz., 85c. PINK BEAUTY - A rich deep rose shade. 1/8 OZ., I5C; 1/4 OZ., 25c; oz., 85c.

SCARLET KING-(New) An intensely deep, rich, pure scarlet; a grand acquisition. $1 / 8$ oz., 20c; 1/4 oz., 6oc; oz., \$I.75.

NEWPORT PINK-Color watermelon pink, fragrant. I8 inches high. $1 / 8$ oz., 20c; $1 / 4$ oz., 6oc; oz., \$2.00.

\section{THUNBERGIA}

Finest Mixed-1/8 oz., I5c; 1/4 oz., 25c; oz., 75c; $1 / 4$ lb., $\$ 2.25$.

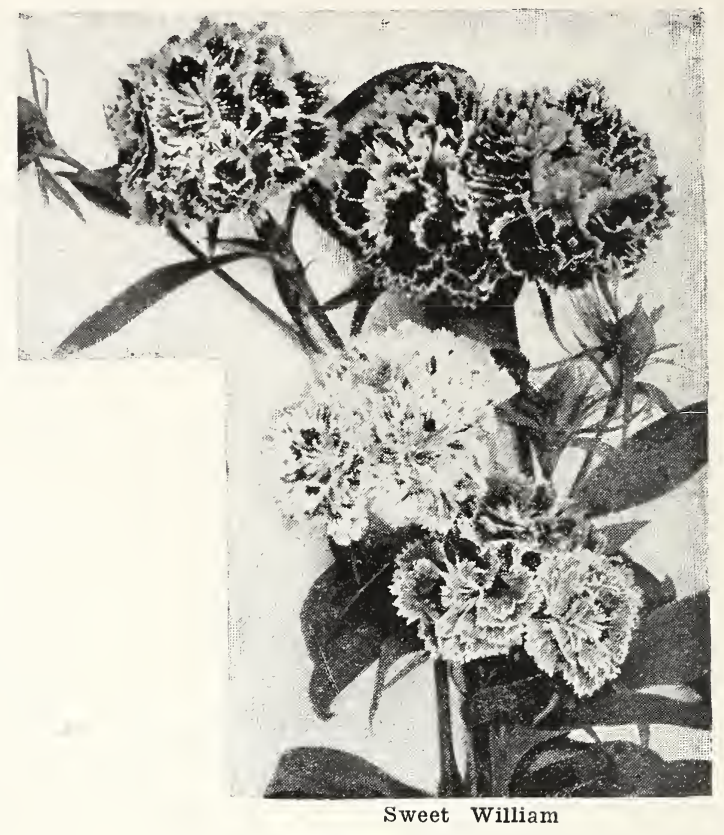

\section{VINCA}

Rosea, Mixed-1/8 oz., 25c; $1 / 4$ oz., 40c; oz. \$.35.

Rosea-Bright rose. $1 / 8$ oz., 25c; $1 / 4$ oz., $45 \mathrm{c}$; oz., \$r.50.

Rosea Alba-White, rose eye. 1/8 oz., 25c; 1/4 oz., 45c; oz., \$I.5O.

Alba-Pure white. $1 / 8$ oz., 25c; $1 / 4$ oz., $45 \mathrm{c} ;$ oz., \$1.50.

\section{VIOLA (Tufted Pansies)}

Sweet-scented Violets are easily grown from seed, and if you can plant them in a cool and moist situation, so much the better. All varieties are of great beauty.

Sweet-scented-Violet-blue. I-I6 oz., 30c; $1 / 8$ oz., 50c; 1/4 Oz., $85 \mathrm{c}$.

\section{Johnson's Grand Spencer or Orchid-Flowered \\ Blush-Pink} SWEET PEAS

Pamphlet on Sweet Pea Culture Free

Johnson's Grand Spencer Mixture

A liberal planting of this mixture will furnish a most magnificent display of Spencer types. All shades of color. Gigantic Waved Spencer Type. Oz., 20c; 1/4 lb., 50c; 1b., \$I.75.

All Flower Seeds Are Postpaid

\section{White}

KING WHITE-Pure, glistening white; gigantic in size and perfect in form. The best white to date. White-seeded. Oz., 30c; $1 / 4$ lb., 9oc; lb., \$2.75.

CONSTANCE HINTON-A mammoth blackseeded white; sometimes tinged with blush at the base of the petals. Oz., 30c; 1/4 lb., 90c; lb., \$2.75.
ELEGANCE-One of the newest. Flowers of immense size; dainty lilac pink on white ground. Oz., 35c; 1/4 lb., 9oc; lb., \$2.75.

ELFRIDA PEARSON-Lovely soft pink throughout; flowers of large size and exquisite form. Oz., 35c; $1 / 4$ lb., 9oc; lb., \$2.75.

\section{Orange}

TANGERINE, IMPROVED-This is the last word in orange Sweet Peas. Large, beautifully formed flowers. Oz., 3oc; 1/4 lb., 9oc; lb., \$2.75. ROBERT SYDENHAM-Deep glowing orange. Oz., 3oc; $1 / 4$ lb., 9oc; lb., \$2.75.

HELEN LEWIS-Orange rose wings; standards crimson orange. Oz., 30c; 1/4 lb., 9oc; lb., $\$ 2.75$.

\section{LAVENDER}

HAWLMARK LAVENDER-New. Pure true lavender of immense size. Oz., 35c; 1/4 lb., 9oc; lb., \$2.75. 


\section{Sweet Peas -Continued}

R. F. FELTON-A very fine clear, deep lavender. Oz., 40c; 1/4 lb., 9oc; lb., \$2.75.

AUSTIN FREDERICK IMPROVED-Giant lavender. Pkt., IOc; oz., 40c.

ASTA OHN-Lavender with a mauve suffusion. Oz., 30c; $1 / 4$ lb., 9oc; lb., \$2.75.

\section{Cream or Primrose}

DOBBIE'S CREAM-Clear, deep cream; perfect form. Oz., 30c; $1 / 4$ lb., \$I.00.

\section{Cream-Pink}

NEW MIRIAM BEAVER-One of the daintiest shades in Sweet Peas. Soft hydrangeapink, tinted salmon. Oz., 30c; 1/4 lb., \$I.00; lb., $\$ 3.00$.

PICTURE-A recent English introduction. Salmon pink; large and of elegant form. Oz., 3oc; $1 / 4$ lb., $75 \mathrm{c}$.

NEW MARY PICKFORD-Beautiful light and dainty cream pink. Oz., 35c; 1/4 lb., 90c; lb., $\$ 2.50$.

MARGARET ATLEE-Rich, glowing pink on cream ground, suffused with salmon on standard and wings. Oz., 3oc; $1 / 4$ lb., 8oc; lb., $\$ 2.75$.

\section{Deep Pink}

COUNTESS SPENCER-The original Spencer variety; lovely clear pink. Oz., 35c; 1/4 lb., \$1.Io; 1b., \$2.75.

HERCULES-Soft rose pink; extraordinary size and substance. An improvement on Countess Spencer. Oz., 35c; 1/4 lb., \$1.00; lb., \$2.75. HAWLMARK PINK-A sensational novelty. Bright pink with a suggestion of salmon. Extra large. Oz., 35c; $1 / 4$ lb., \$1.00; lb., \$2.75.

\section{Rose and Carmine}

ROSABELLE_Deep rose with a white blotch at the base of standard and wings. Oz., $35 \mathrm{c}$; 1/4 lb., \$1.00; lb., \$2.75.

GEORGE HERBERT-Magnificent rich rosy carmine self. Extra large. Oz., 35c; 1/4 lb., $90 c ; 1 b ., \$ 2.75$.

\section{Salmon and Cerise}

BARBARA-Rich salmon self, of finest form, Oz., 35c; 1/4 lb., 90c; lb., \$2.90.

ILLUMINATOR-Glowing cerise-salmon, suffused with orange. Oz., 35c; 1/4 lb., 9oc; lb., $\$ 2.90$.

\section{Orange-Scarlet}

DEFIANCE-Pure flaming orange-scarlet. Oz., 40c; 1/4 lb., \$1.00; lb., \$3.25.

FIERY CROSS-Fire-red or rich orange-scarlet, without any shading. A famous variety; one of the brightest in existence. Oz., 30c; $1 / 4$ lb., \$1.00; lb., \$3.00.

ROYAL SCOT-Scarlet. Oz., 30c; 1/4 lb., 9oc; lb., $\$ 2.75$.

THE PRESIDENT-Brilliant orange-scarlet; largest size. Oz., 30c; 1/4 lb., 90c; lb., \$2.75.

\section{Scarlet and Crimson}

\section{VERMILION BRILLIANT-Intense} pure scarlet. Oz., 30c; $1 / 4$ lb., 90c; lb., \$2.75. KING EDWARD SPENCER-Bright crimson-scarlet; flowers of the largest size and finest form. Oz., 30c; $1 / 4$ lb., 9oc; 1b., \$2.75.

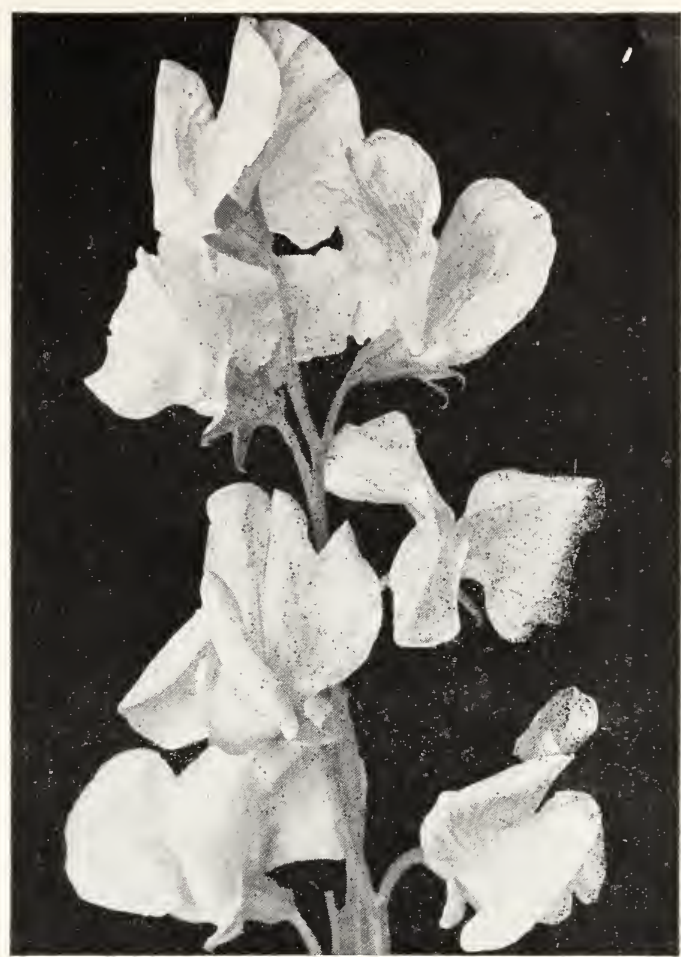

Sweet Peas

CRIMSON KING-Rich deep crimson. Oz., 7oc; 1/4 lb., 9oc; lb., \$2.75.

DOBBIE'S SUNPROOF CRIMSON - A bright, lasting color; requires no shading from the sun. Oz., 30c; $1 / 4$ lb., 90c; lb., \$2.75.

\section{SEMESAN}

Semesan, applied in dust or liquid form to flower and vegetable seeds before planting, is harmless to the seed but deadly to disease organisms that may be on the seed. One ounce treats 15 pounds of seed. Effective in controlling damping off in the seed-bed. 2 ozs., 5oc; lb., $\$ 2.75 ; 5$ lbs., $\$$ I3.00.

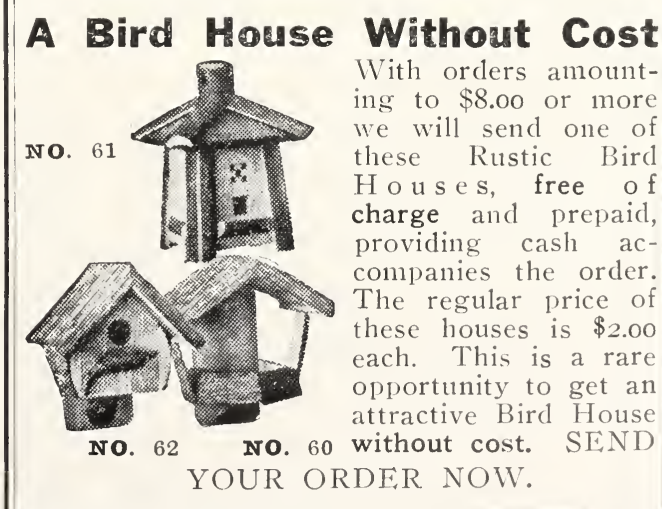




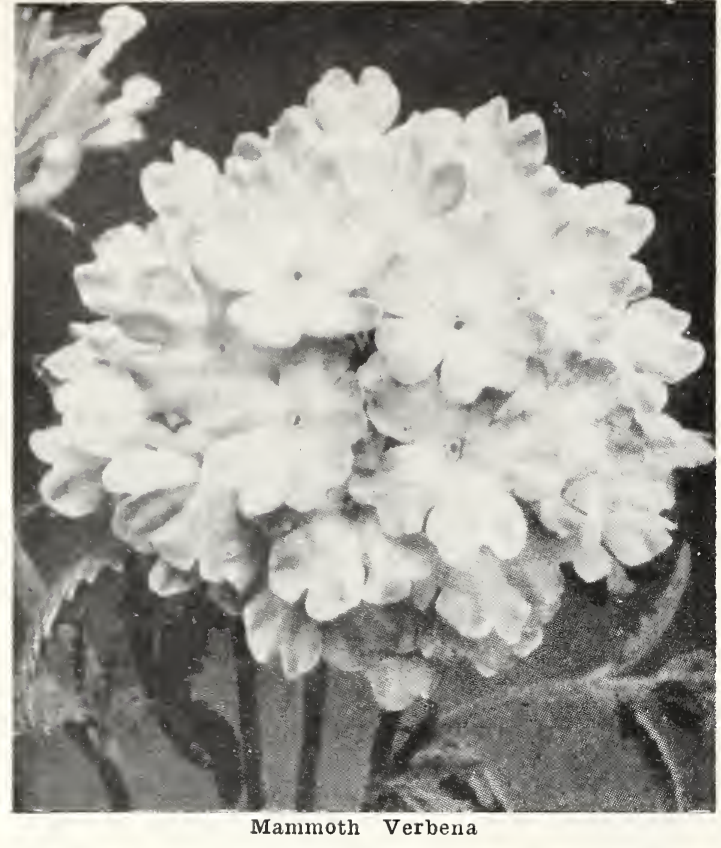

Mammoth Verbena

\section{ZINNIAS}

\section{Double Dahlia-flowered}

This splendid new Zinnia will greatly increase the popularity of this flower. The plants are of strong, vigorous habit, from $2 \frac{1 / 2}{3}$ to 3 feet high, producing mammoth flowers 4 to 6 inches across by $2 \frac{1 / 2}{2}$ to 3 inches deep, very similar in appearance and form to the double decorative dahlia.

\section{Dahlia-flowered Zinnias in Color}

Oriole-Orange and gold bicolor.

Exquisite-Tyrian-rose.

Golden State-Orange-yellow.

Polar Bear-Pure white.

Crimson Monarch-Crimson.

Scarlet Flame-Bright scarlet.

Lemon Beauty-A pastel shade.

Dream-Deep lavender.

Purple Prince-Rhodanthe-purple.

Any of the above 9 colors, $1 / 8$ oz., 3oc; $1 / 4$ oz., 5oc; Oz., \$1.75.

Johnson's Special Mixture Dahlia-flowered Zinnia.-Our special mixture of this new type of Zinnia is made up from the separate colors. The brilliancy of color and the giant size of the flowers will appeal to those wishing the best. $1 / 8$ oz., 25c; 1/4 Oz., 40c; oz., \$I.30; 1/4 lb., \$4.00.

\section{Double Pompon Zinnias}

All Colors Mixed-These Zinnias grow 2 feet high and are sturdy and bushy. They are also sometimes called "Lilliput" on account of their beautiful little flowers, which are very double and cone-shaped. $1 / 8$ oz., $15 \mathrm{c} ; 1 / 4$ oz., $25 \mathrm{c} ;$ oz., $75 \mathrm{c}$.

\section{JOHNSONS MAMMOTH VERBENAS}

Verbenas are much more vigorous and free flowering if raised from seed than if grown from cuttings. The plants thrive in any good garden soil and are low, spreading, forming a carpet of green foliage which makes a dense background for the brilliantly colored flowers, ranging in color from snow-white, through the different beautiful shades of pink and blue, to the deepest red.

Mammoth Defiance-Bright, rich scarlet flowers; small leaves. Pkt., Ioc.

Mammoth Blue Varieties-Showy; distinctive; fine for edgings. Pkt., Ioc.

Mammoth Pink Shades-Many very brilliant shades of pink. Pkt., Ioc.

Mammoth Striped Varieties-Beautiful; a rich collection. Pkt., Ioc.

Mammoth Pure White-Large trusses of purest white flowers. Pkt., Ioc.

Mammoth Purple-Deep royal-purple. Pkt., Ioc.

Any of the above Mammoth Verbenas, $1 / 8$ oz., 20c; 1/4 Oz., 35c; Oz., \$1.25; $1 / 4$ lb., \$4.00.

Johnson's Mammoth Mixed Verbenas-1/8 oz., 20c; 1/4 Oz., 35c; Oz., \$I.I5; 1/4 lb., \$3.50.

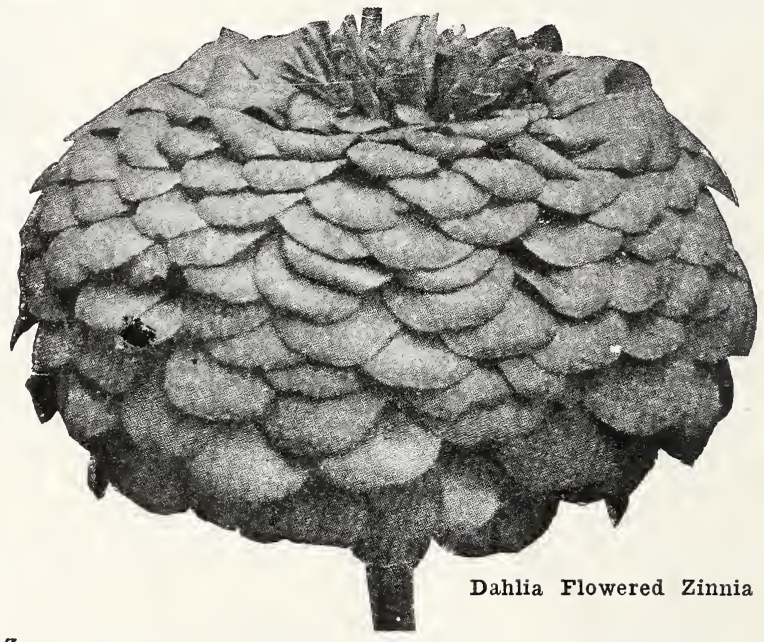

Prepare Seed Beds Carefully

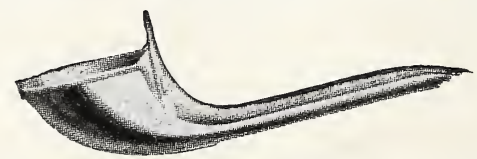

This is especially true when sowing extremely small seeds. We suggest the use of a "Sow-Rite" seeder; sells for only 75c postpaid, and will save its cost many times in sowing proper quantity of seed to a given space. Usually seed is sown too thickly. Order today.

\section{JOHNSON'S SEED STORE SEEDS THAT PRODUCE}

